\title{
The Inventory Stele: More Fact than Fiction
}

\author{
Manu Seyfzadeh1, Robert M. Schoch² \\ ${ }^{1}$ Independent Researcher, Lake Forest, CA, USA \\ ${ }^{2}$ Institute for the Study of the Origins of Civilization, College of General Studies, Boston University, Boston, MA, USA \\ Email:manu@cheopspyramid.com,schoch@bu.edu
}

How to cite this paper: Seyfzadeh, M., \& Schoch, R. M. (2018). The Inventory Stele: More Fact than Fiction. Archaeological Discovery, 6, 103-161.

https://doi.org/10.4236/ad.2018.62007

Received: March 6, 2018

Accepted: April 16, 2018

Published: April 19, 2018

Copyright $\odot 2018$ by authors and Scientific Research Publishing Inc.

This work is licensed under the Creative

Commons Attribution International

License (CC BY 4.0).

http://creativecommons.org/licenses/by/4.0/

\begin{abstract}
The Inventory Stele tells a story about Khufu and the Great Sphinx which contradicts the current mainstream narrative of when the Sphinx was carved. The story's historical relevance has long been challenged based on its mention of names and certain details which are believed to be anachronistic to the time of Khufu. Here, we address the elements commonly cited by the critics one by one and find that they are largely based on misconceptions in part due to errors and oversights contained in the two commonly referenced translations and based on a missing context which relates to the economics and symbolism of supplying provisions to the royal house. We reconstruct a more plausible scenario of why and when the text may have been originally composed and who its target audience was. From our analysis we conclude that while we cannot rule out a couple of minor modifications of names from the original written version we date to the $5^{\text {th }}$ Dynasty, there is no plausible reason to dismiss the entire account recorded in this Late Period version on those grounds alone and that the events it describes appear more factual than fictitious.
\end{abstract}

\section{Keywords}

Inventory Stele, Sphinx, Khufu, Giza, Isis, Henutsen, Osiris, Satet, Hieroglyphic, Heka

\section{Introduction}

The Inventory Stele is a limestone tablet made by an unknown temple scribe during the reign of the $26^{\text {th }}$ "Saite" Dynasty of Egypt's Late Period (664-332 B.C.E.) to showcase a temple inventory of precious statues. This was a time when a fragmented Egypt had been unified under Psammtik I and made independent from Assyrian rule. The stele was discovered by Auguste Marriete in 1858 near a temple which extends east from Khufu's southernmost queen pyramid G1c and which was expanded in the $26^{\text {th }}$ century B.C.E. from earlier beginnings. Rebuilt at least twice, the temple incorporates G1c's chapel on its western limit and ad- 
jacent $4^{\text {th }}$ Dynasty mastabas on its eastern end. This temple is known as the Temple of Isis to whose inventory of statues the stele refers. The statues listed on the stele are those of: Min, Wpwaut, Horus/Nekheny (?), Thoth, Isis, Nephthys, Serqet, Ptah, Sekhmet, Osiris, Apis, Nefertum, Uraeus, and the Great Sphinx, the last named both "statue" and "Horemakhet". The temple's origin by G1c is believed to be circa one thousand years older, perhaps, though not proven to be, first built during the $18^{\text {th }}$ Dynasty of Egypt's New Kingdom.

Inscribed into the Inventory Stele's frame, lowest register, and pedestal are a few lines of hieroglyphic text which have stirred controversy because they explicitly contradict the nowadays mainstream theory that Khufu's son Khafre constructed the Great Sphinx (for an example of a contrarian Egyptological opinion see Stadelmann, 2000). The text has been translated by James Henry Breasted (1906), by Georges Daressy (referenced in Zivie-Coche, 1991) and Christiane Zivie-Coche (1991). It reads as a detailed historical account of Khufu discovering and rebuilding an old temple, restoring its divine temple statues, building his pyramid and that of his wife Henutsen, repairing a worn and damaged Great Sphinx according to records of its prior image, presenting animal offerings to the gods, surveying a lightning-struck Sycamore tree, and commemorating these activities on steles for the temple and the Sphinx.

This account clearly implies that the Great Sphinx predates the Giza pyramids. The "Khafre-Sphinx Theory" (AERA, 2017), by contrast, proposes that the entire Sphinx was made after Khufu's pyramid as part of Khafre's Giza building program which also included Khafre's pyramid, the causeway, and the Valley and Sphinx temples. Consequently, the "Khafre-Sphinx Theory" and the story told on the Inventory Stele cannot both be true.

The historical authenticity, in its entirety, of the text written on the Inventory Stele has been rejected by some Egyptologists chiefly because it mentions deities like Isis and Osiris and refers to the Sphinx as Hurwn, none of which are believed to have been recognized mythological actors in Egypt's state pantheon of Khufu's time. Various critics have also pointed out that Isis' epithet cited in the text as "Mistress of the Pyramid" is incorrect, that Khufu is introduced at the head of the text in a manner atypical of customary Old Kingdom style, that the original temple of Isis could not have predated the $4^{\text {th }}$ Dynasty mastabas over which it extends, and that there is no record of Khufu's wife Henutsen having been a princess as the text states. Based on these observations and the overall textual quality and poor execution in stone, virtually the entire story of the stele has been categorically declared a tale of New Kingdom and Late Period priestly lore to coat the Temple of Isis with a patina of ancient aura for attracting donations and state support in the form of temple provisions.

In this paper, we reexamine the historical value of the Inventory Stele's inscription and appraise it in a more measured manner. We show evidence that the core statements of the text could be based on historical facts and should not be summarily dismissed even if the Isis temple's Saite-era scribe, in a worst-case scenario, made some minor adaptions to make it relevant to his or her time. We 
first present some needed background material to aid the reader in their own appraisal of our findings. In the Results section, we focus our rationale on the most disputed part of the Inventory Stele and then individually address each element of the critics' rationale against its historical authenticity. Our main goal in the discussion is to reconstruct a plausible scenario in which the original text material may have been generated and dispel the notion that the stele was made to commit "pious fraud". We conclude that the events described on the Inventory Stele are probably true and, if anything, well reflect the economic activities commonly conducted during the Old Kingdom. When viewed within this context, the narrative in the text that Khufu repaired the House of Isis, built his pyramid and that of Henutsen, and knew, possibly even repaired, the Great Sphinx monument appear rather ordinary and not as contentious as they have been deemed when viewed in isolation.

\section{Background}

Isis. The earliest widely acknowledged record of Isis occurs in the Pyramid Texts of Unis (Unas) at Saqqara, written circa two hundred years after the time of Khufu, where she is mentioned at least nine times. There is a possible reference to Isis in the sun temple of $5^{\text {th }}$ Dynasty king Niuserre Ini at Abusir (reigned late $25^{\text {th }}$ century B.C.E.), alive circa 150 years after the time of Khufu (reigned early-middle $26^{\text {th }}$ century B.C.E.). The Pyramid Texts hint that Isis' origin as a worshiped goddess is in the Delta region, Lower Egypt (PT 217, Unis). The spelling of Isis' name in Old Egyptian was written as Gardiner Q1-X1 (e.g. PT 366) ${ }^{1}$. Afterwards, various spellings can be observed. Examples include Gardiner Q1-X1-B1 with title G36-D21-I12 (e.g. Petrie Museum, "Isis the Great Goddess" Stele) in Middle Egyptian; in New Egyptian for example as Gardiner Q1-X1-H8-B1 with title V30-X1-N1 ("the sky mistress") as seen on Stele 40-19-2 at the Penn Museum; in the Third Intermediate Period as Gardiner Q1-X1-H8 (e.g. the Tomb Stele of Psuennes); and in Late Egyptian as Gardiner Q1-X1-H8 with title G36-D21-R8-G15 ("the great divine mother"), for example as seen on the Stele of Irethoreru (Brooklyn Museum).

Osiris. A definitive mention of Osiris is above the false door of the tomb of Ptahshepses at Abusir, who was born when Khufu's grandson Menkaure was king. Osiris is the first god to whom offerings are dedicated in this architrave inscription which means that he became a major god of Egypt not later than during the life-time of this vizier and Re-Priest of Niuserre, sixth king of the $5^{\text {th }}$ Dynasty. Like Isis, Osiris prominently features in the later Pyramid Texts of Unis where he is mentioned well over one hundred times. As is the case with Isis, the origins of Osiris appear to be in Lower Egypt (PT 217, Unis). Osiris was typically spelled Gardiner Q1-D4. An alternative spelling was Q2-D4 demonstrating that

${ }^{1}$ In this paper, we use Gardiner's nomenclature (Gardiner Sign List, 1957) to refer to hieroglyphic symbols and English phonetic text, not the British transcription system, to aid those readers unfamiliar with the latter in their pronunciation. A hieroglyph chart can be found at the end of this paper which lists the symbols mentioned in this paper. 
hieroglyph substitutions in the names of gods occurred (for example see the Limestone Stele of Perinefer from Abydos; Bologna, Museo Civico Archeologico).

Satet. This goddess was worshiped on Elephantine Island as the "Mistress of the Sky" since at least the $3^{\text {rd }}$ Dynasty (Wilkinson, 2003: p. 165). The several rebuilds of her temple on the island were consistently realigned to track the horizontal wander of the star Sirius over two millennia (Wells, 1985). She was worshiped as the consort of Khnum, the patron god of Khufu. The name Satet in Egyptian was spelled Gardiner S29-V13-X1-S22-N25 (e.g. PT 439) and later the F29 symbol replaced S22, e.g. as seen on the current temple of Satet on Elephantine Island. Invariably there were two "t" consonants, either X1 or V13. Near the Elephantine temple, a small step pyramid made from granite was built by Huni or Nebka in the late $3^{\text {rd }}$ Dynasty. In the Pyramid Texts of Pepi, Satet is mentioned four times.

Hurn/Hurwn/Haurun/Hwurna/Hwrna/Hul/Hu (and other variants); Hor-em-Akhet, Hor-Akhty. Selim Hassan traced the origin of two of the Great Sphinx's names appearing on some votive steles (written symbolic offerings) he discovered during his 1936-1938 Giza excavations, Hurwn and Hul, to Yamnia in Canaan, where a hawk was worshiped at "Bet Harun", the House of Hwron (Hassan, 1953: p. 253). He proposed that Canaanite settlers in Egypt who established a base near Giza called Horonopolis (Harronia) at the beginning of the $18^{\text {th }}$ Dynasty (Hassan, 1953: pp. 265-267) imported this hawk cult and conflated it with the Great Sphinx. Specifically, they identified their hawk deity Hwron with both Atum, the Egyptian god of the evening sun, and Horemakhet, the New Kingdom name of the Great Sphinx (Hassan, 1953: pp. 253-267). The mention of the name "Hurwn" on these foreign-appearing New Kingdom era steles convinced Hassan that they were the original source of this name for the Sphinx on the much later Inventory Stele (Hassan, 1953: p. 153; see also Hassan, 1949: pp. 145-155). Consequently, he concluded that the original temple of Isis at Giza must have been built during this time as well (Hassan, 1953: p. 111). Hassan based this reasoning on what he thought is the proper interpretation of the name "Hurwn", pointing to its misinterpretation by Swiss Egyptologist Henri Édouard Naville, who read it as "Hu" instead of "Hul" or "Hur", a mistake, according to Hassan, widely copied by other scholars (Hassan, 1953: p. 222) and disseminated; we confirm that the Vygus dictionary, rightly or wrongly, contains this entry (Vygus, 2015: p. 2216). Hassan's core thesis was that with the Canaanite name Hurwn also came a Canaanite hawk myth which, in the belief of the settlers, replaced the mythology of the Great Sphinx. It is this foreign hawk myth associated with the name Hurwn which is anachronistic in the Khufu story of the Inventory Stele thereby invalidating it (Hassan, 1953: p.266), since the settlers came long after the Old Kingdom. Hassan did not elaborate on the possibility that Hurwn simply referred to a long-established attribute of the god(dess), represented by the Great Sphinx, which originated in Egypt and not abroad and which could have been culturally exported to the Levant and beyond. 
"Hu", from "Hu-Rw(n)", nevertheless was an aspect of the Memphite god Ptah and thus of the ultimate Heliopolitean creator god Atum, separately personified as a god (Wilkinson, 2003: pp. 110-111; Allen, 2014: p. 196), and thus also a component of "Heka" magic, the act of creating through annunciation. $\mathrm{Hu}$ is attested in the Pyramid Texts and can be seen on New Kingdom tomb walls predating Amenhotep II and Thutmose IV (who substantially instigated the Great Sphinx cult revival during the late $18^{\text {th }}$ Dynasty) traveling at the stern of the solar boat with the dead sun and king through the underworld. It appears likely that any votive steles placed around the Great Sphinx by Canaanite settlers or other devotees must date to a time after Thutmose IV cleared the monument from sand and built an enclosure around it. "Ru", part of the second syllable, was one of the Egyptian words for "lion". The association between lions and writing is well documented since the time of Narmer, symbolized by the scribes' patron goddess Mehit and mentioned in association with Heka priests.

Expanding on Hassan's thesis, to ethnic Canaanites their hawk god Hwron was the equivalent of the Egyptian (Ra-)Horakhty known from the Pyramid Texts, who Hassan was able to also link to Atum and Horemakhet, the name of the Great Sphinx from at least the time of Thutmose I (Hassan, 1953: p. 242). Indeed, Hassan shows a stele of a presumed New Kingdom member of the military (Hassan, 1953, the stele shown on p. 149, the inscription on p. 256) containing this inscription:

"Adoration to Hor-em-akhet, in his name Hwrna. I give praise to thy beautiful face, I make content thy beauties. Thou art the Only One, who will exist till eternity, while all people will die. Mayest thou give me good life, while I am following thy Ka. For the Ka of the Fan-bearer of the Phyle of the Amon-nakht Regiment, Khery-itef-u."

Regarding this inscription, Hassan (1953: p. 256) comments:

Here we have a definite declaration that Hwrna is a god who is identified with Hor-em-akhet, and that the two are regarded as the personification of the One Eternal God. It is not often that we are so fortunate to get such a clear and definitive statement from the monuments.

However, it is apparent that Kheryitefu, who does not appear to be a Canaanite, still separates the Ka-identity (i.e. its life-force) of the Egyptian god believed to dwell inside the Great Sphinx from the name Hwrna and there is no indication of the "Ka" of a foreign cult. To understand how this ostensible name conflation may have occurred, we must first review the mythology behind the Egyptian names associated with the Great Sphinx.

The meaning behind the Atum-Horakhty-Horemakhet trinity is explained in the following summary based on Hassan (Hassan, 1953: p. 241): Horemakhet, literally "Horus in the Horizon", specifically applies to the Great Sphinx because of the dual meaning of "Akhet" = horizon/tomb, which implies a royal necropolis like Giza. Also, the monument sits in a depression flanked by two hills mi- 
micking the image of a setting sun between to mountains, the hieroglyphic symbol used to denote "horizon". And furthermore, the Great Sphinx can be viewed as sitting "between" the two major pyramids at Giza. This explains why the monument was apparently regarded as the guardian of the dead King's resting place in his western horizon, the realm of the dead where the evening sun Atum sets. Hence in New Kingdom mythology, the Great Sphinx assumed the Old Kingdom role of Anubis as can be seen in the standard offering invocation of that era compared to the older formula (Hassan, 1953: p. 238; however, this is not to say that the Great Sphinx was in actuality ever a representation of Anubis, as some authors have suggested-the Sphinx faces east whereas Anubis typically faced west, as for instance with the Anubis shrine of Tutankhamun; see further discussion in Appendix 8 of Schoch \& Bauval, 2017). The name Horemakhet, however, dates to as early as the Middle Kingdom (Hassan, 1953: p. 242).

The counterpart of the living Horus king was the spirit of the dead Horus king in the sky, Horakhty. As a Horakhty, visible on the horizon during dusk and dawn, the king was imagined to be accompanying the sun god Re in his solar boat traversing the celestial waters during the day. During the night, the night hawk, perhaps seen as the king's personified "Ba" aspect, accompanied the "Ba of Re" Khnum in the night boat through the waters of the underworld where they were resurrected through merging with Osiris.

One can thus deduce the guardian function of the lion and the hawk and compare it to what the falcon Horus represented: The lion guarded the dead king in the realm of the living and the hawk guarded (or personified) the dead king's "Ba" in the realm of the dead. The living king was one with Horus, a falcon in the sky above. When he died he became a celestial spirit (e.g. a star or planet) in the heavens above Earth and his son become the new Horus king.

It appears then that the Egyptian night hawk, personified as the god Sokar, and some Sphinx depictions showing the monument with the head of a hawk, may have reminded New Kingdom era Canaanite settlers-perhaps during the reign Amenhotep II-of their hawk god Hwron initially, both being protectors of the king. Later, Hwron became associated with Horus as well and the name seems to have been interchangeable with Horakthy (Hassan, 1953: pp. 249-250). Through this mythological link to Ptah-Sokar-Osiris via the hawk imagery, Hwron became first conflated with the other guardian, the Great Sphinx monument, and then also with its heavenly counterparts Horakhty and Atum, the other two members of the trinity (Hassan, 1953: p. 238); at least this is what is implied by Hassan's theory. Evidence for such an association between a crouching lion and a crouching hawk-lion exists, but demonstrably has much older Egyptian origins (Hassan, 1953; compare the axe of Ahmose I, p. 177, with the predynastic slate palette, p. 146, on which both creatures appear). Also, Hassan gives examples of steles showing Horemakhet either as a hawk or next to a hawk-headed god (Hassan, 1953: p. 246) suggesting that Hwron could be that hawk, but this could have been simply a new name for an already existing Egyp- 
tian god, i.e. Sokar or even Horus, not a new god added to the preexisting Egyptian trinity. For example, we think it is conceivable that Hurwn could simply be a derivative of "Hrw-Rw" (Horus-Lion) created to emphasize this dual nature of the god(dess) inside the Great Sphinx statue, or a derivative of "Hw-Rw" (The Lion's Annunciation) created to emphasize the role in creation, magic, and writing, or a derivative of "Shw-Rw" to emphasize the invisible nature of air and shadows identified with the lion god Shu and the primordial role of the lion's ghostly spirit in hunting after shadows in the netherworld when so called upon by a shaman Sem priest (see the segment on Heka below). Finally, Hurwn could simply be a derivative of Anhur(et), the male consort of the Thinite era lioness Mehit, identified with the Sphinx we believe (Seyfzadeh, et. al., 2017), with Anhur and Mehit forming the Upper Egyptian counterpart of the Lower Egyptian Shu and Tefnut.

In summary, Hassan's theory hinges on how one reads and translates the hieroglyphic name "Hurwn" and to what extent the meaning of the name relates to a foreign import or a well-established domestic belief. Either the name originally signified a Canaanite hawk god who protected the king as did the Egyptian Sokar (with whom Ptah and Osiris became conflated) or it represented an Egyptian concept like the "annunciation" attribute of Ptah, its magic application Heka used by Sem priests, or a word play to better express the dual nature of Horemakhet, none of which were foreign concepts. Either way, the name "Hurwn" and its variants were applied to the Great Sphinx no later than the New Kingdom (and possibly earlier).

Heka Magic. The concept of mimicking creation by invocation was Heka, the same power of announcement ("Hu") possessed by Ptah in the Memphite theology and by Atum in the Heliopolitean theology. To illustrate the concept with a well-documented example, Wolfgang Helck explained how dynastic Egyptians used Heka to ritualize their prehistoric ancestors' custom of making a statuette of a deceased to keep him, his memory that is, alive for his family (Helck, 1987: pp. 21-30). The originally prehistoric tribal custom involved the carving of an ivory statuette inside a ritually demarcated enclosure followed by imbuing it with the shadow, i.e. an outlined image, which had separated from the dead body and escaped into the underworld. This shadow had to be first captured from the netherworld by the "Sem" shaman priest, the same long-haired figure seen in front of Narmer, there called "Thet", on the verso of the Narmer Palette. It appears as if the Sem had to don a leopard skin ("Khnt Ba") in order to fall into a trance state from within which he recruited the help of certain animal spirits-in the example of the text analyzed by Helck a spider, a locust, and a mosquito-to capture the shadow and bring it back into the realm of the living (Helck, 1987: pp. 23-24). Once so captured and imbued into the statuette, its face was painted and inlaid by adding eyes, eyebrows, and a mouth. Finally, the deceased's son was sent for with a swallow (the bird) to come and take the statuette to a shrine called White Chapel ("Iteret"?). 
The belief system behind this custom is fundamentally the same as the one behind the idea of preparing a mummy out of a dead corpse in order to create a vessel for the dead king's shadow ("Shjw", "Shwt") so that he can be reborn as an immaterial Akh spirit from this material base once his $\mathrm{Ka}$ and $\mathrm{Ba}$ reunite in the underworld. To preserve the spirit of the original custom, the craft of statue making became verbally ritualized as Heka spells, which also explains Ptah's association with Heka as the patron god of craftsmanship. Writing in other words was the advanced, more abstract craft of creation of the dynastic Egyptian state which evolved from the primordial, more concrete figurine making custom of its tribal origins. Heka spells became incorporated into the Offering Ritual of the Pyramid Texts on the north wall of the sarcophagus chamber, i.e. the possible equivalent of the Sem's enclosure. The Mouth-Opening Ritual of the Pyramid Texts contains recognizable verbal remnants of the original statuette making custom (Helck, 1987: pp. 28-29), but most allusions still remain a mystery to date.

The Heka version of the statuette custom involved the verbal recitation by a lector priest of a series of spells whose phrases contained certain key words invoking the key elements of this custom, for example first the Sem himself and then the animal(s) who help the Sem to catch the shadow of the deceased. Instead of directly naming these elements, the Heka spell used a word or a combination of two words which sounded like the actual word to be invoked and which, when pronounced, became activated and presumably made subconsciously real to the funerary attendants by animating their memories and imagination. In one example, an anagram of the word for mosquito "khns", i.e. "khsn", was used to animate its ka-spirit to help the Sem catch the deceased's shadow (Helck, 1987: p. 23). In other words, the activating spell's textual content may have had little to do with the meaning of words to be activated which is in line with the Egyptian language itself, where most hieroglyphs encode only a sound often unrelated to what is being depicted.

Royal names. As Egyptian kingship progressed from their early dynastic beginnings, kings were given more titles and associated names. To the initial "Horus" name (e.g. "Horus-Aha" or "Horus-Djer") were added the "Two Ladies" name and the "Golden Horus" name. By the $5^{\text {th }}$ Dynasty, the older "Sedge and Bee" throne name and the newer "Son of Re" name, both of which were accentuated by placing them in a cartouche, completed the full set of five names (Allen, 2014: pp. 81-83).

Egyptian Grammar (Allen, 2014). The Inventory Stele was produced in Egypt's Late Period. Whether its content is original, or a copy of an older text is at issue here. Two forms of the Late Egyptian written language can be grammatically discerned: Literary and Non-Literary Egyptian. The difference is based on whether prepositions are used, the presence or absence of certain verb forms, and a few unusual syntactic features like inserting a preposition where it should not go otherwise (Cerný \& Groll, 1993: p. LVI). These three features tend to be 
linked, i.e., if one is present, the other two are as well, indicating a unique language form and not just a stylistic feature.

There was also a third form, "Traditional Egyptian” (James P. Allen, personal communication). The key question at hand is whether the Inventory Stele's text was originally written in true Old Egyptian or if it is an artificially "aged" text composed later in Traditional Egyptian. As Old Egyptian evolved to become Middle and Late Egyptian, characteristic uses of certain verb forms, possessive adjectives, and marking the plural of nouns changed. For example, the use of the sdm.n.f verb form ("he has heard") to express completed action was common during Old and Middle Egyptian but made way for the $s \underline{d} m . f$ ("he heard") by the Late Period (Allen, 2014: pp. 267-268). Similarly, the genitival adjectives " $n$ ", "nu", and "net" (e.g. "X of Y") used in Old and Middle Egyptian made way to just one, Gardiner N35 " $n$ ", by the time Middle Egyptian was no longer spoken (Allen, 2014: p. 51). The use of the triple repeat to indicate the plural, likewise was abandoned with few exceptions for simple strokes, the plural determinative (Allen, 2005: pp. 45-46; see also Allen, 2013).

Therefore, it is sometimes possible to date a text, whose content is at issue as is the case here, by examining the choice of words and the way words are put together into sentences according to the rules of grammar which prevailed when the text was conceived. This type of epigraphic analysis is complicated by the fact that literary texts might be artificially aged by using an older form of the language. On the Adoption Stele for example (Caminos, 1964), archaic Egyptian was still used as a stylistic feature to convey an aura of gravitas to the audience and only the occasional lexical or grammatical "slip-up" reveals the true time of the text, if the content itself does not make it obvious. This Late Period stylistic use of older grammar is called "Traditional Egyptian".

\section{Results}

Rationale. For our analysis, we divide the text of the Inventory Stele into 4 sectors (Figure 1): " $\mathrm{L}$ " is the inscription which begins center top of the stele's frame and runs down the left towards the base. "R" is the inscription which begins where " $L$ " begins and runs down the right side towards the base. " $B$ " is the initial text in the rightmost vertical columns on the bottom register of the stele up to "Lord of Rostaw" in the translation and "P" begins in the middle two columns, extends through the entire text on the pedestal (Figure 2 and Figure 3), and ends with the last two columns of inscription by the Sphinx on the left. The scribe inserted a blank column to clarify that the columns to the right and left of it are non-contiguous. Contiguous text separated by this arrangement was marked with a few duplicated words to guide the reader through this somewhat haphazard sequence. The text makes most sense when read in the order R-L-B-P, but a few gaps in $\mathbf{P}$ due to deterioration of the stele hinder a full interpretation. George Daressy, on whose translation Selim Hassan depended (Zivie-Coche, 1991: p. 238) attempted to overcome gaps with educated guesses, for 


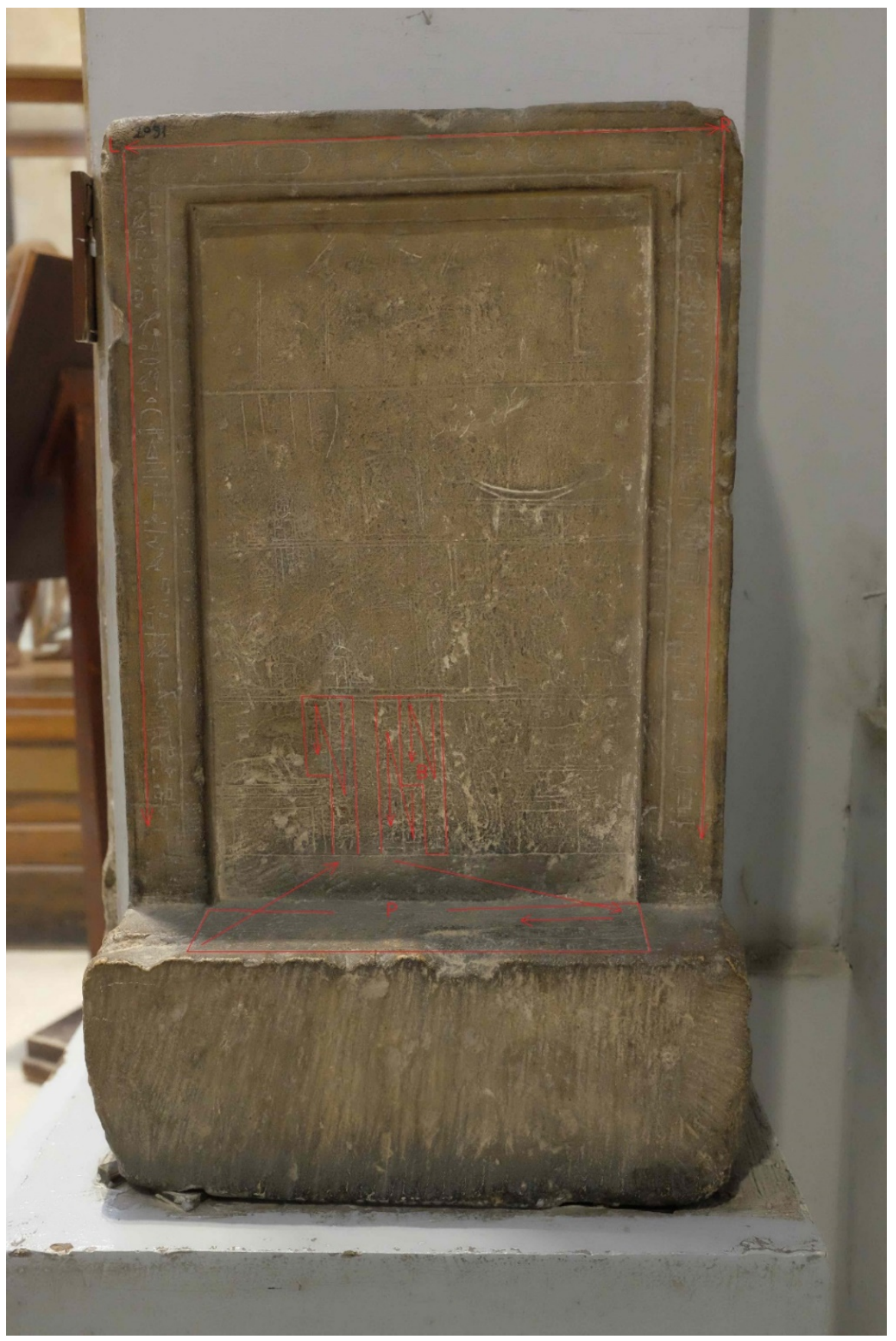

Figure 1. Inventory stele, Egyptian Museum, Cairo. In the center, the apparition window, are four registers depicting images of gods. Indicated in red, we designate sectors Left Frame, Right Frame, Base, and Pedestal (L, R, B, and P) which contain the text discussed in this paper. Arrows indicate the direction of writing on the frame. $\mathbf{B}$ is in the right-most $1 \frac{1}{2}$ columns on the fourth register. $\mathbf{P}$ includes the middle $1 \frac{1 / 2}{2}$ columns of text on the fourth register from the top, the four horizontal rows on the stele's pedestal, and the left-most $1 \frac{1}{2}$ columns on the fourth register next to the Sphinx. Photo courtesy of Robert Schoch, March 2017; modified.

example the segment dealing with the nemes (Figure 4). A summary of the commonly accepted content of each section follows: 


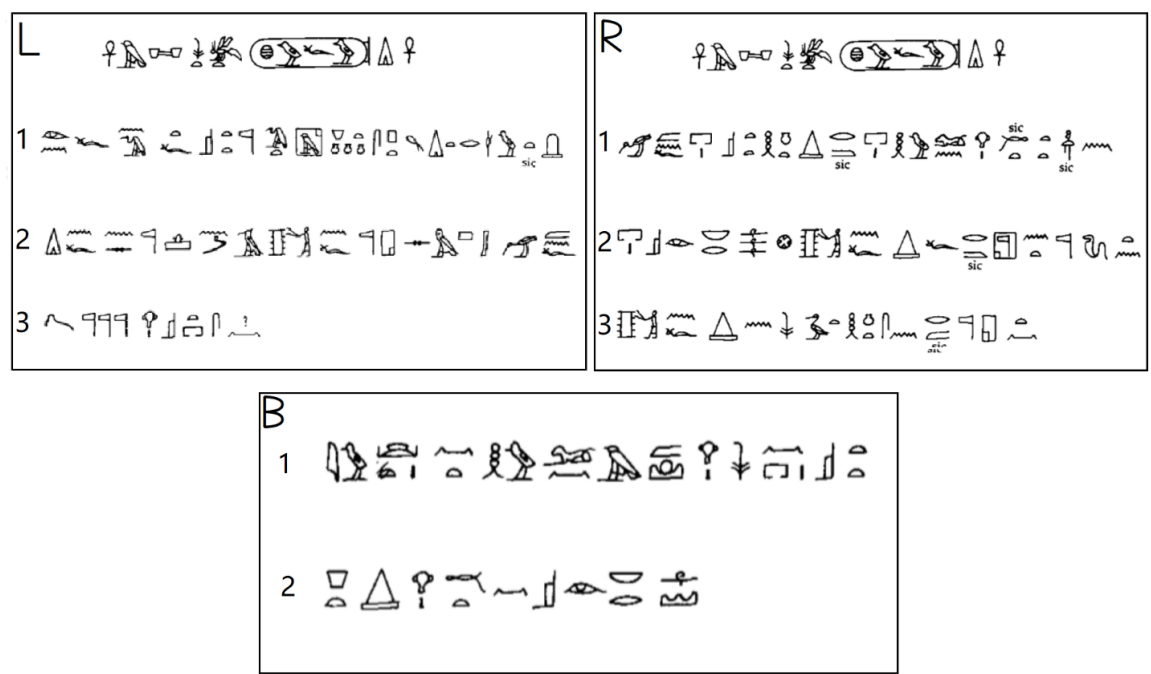

Figure 2. Hieroglyphic transcription of Sectors L, R, and B (from Zivie-Coche, 1991). "Sic" marks where the author presumed errors on the part of the stele's scribe. Specifically, she marked Gardiner X1 (loaf), first row in the left sector and the prepositional phrase " $\mathrm{r}-\mathrm{m}$ " twice in the right sector as well as the word "meh-it" and the standard-mounted feather sign for "west", "imentet", presumably noting its unusual placement after the double X1 (loaf over loaf) instead of before.

R: Khufu has found Isis' House in relation to the Sphinx and the House of Osiris and builds pyramids for himself and princess Henutsen next to the Temple of Isis.

L: Khufu records a decree on a stele for his divine mother Isis and rebuilds her temple which he has discovered. He restores the gods' places.

B: The location of the elements of the Sphinx complex is clarified.

P: Plans are reviewed to repair and decorate the Sphinx. Khufu visits the site of a Sycamore tree near the Sphinx struck by lightning. He restores a record of animals killed in the area and sets a table with vases containing them. In a dream, he is instructed to record a decree by the Sphinx which will last forever in stone facing east.

Critics of the Inventory Stele question various elements of sectors $\mathbf{L}$ and $\mathbf{R}$. Therefore, they categorically dismiss $\mathbf{P}$, which goes beyond a mere statement of Khufu bearing witness to the Sphinx he is not believed to have known if the Khafre-Sphinx Theory is correct. P includes some details of what Khufu did to the Sphinx and hints at prior records of its creation not witnessed by Khufu. Yet these details do not amplify the perceived antiquity of the Temple of Isis in the stele sceptics' fraud theory, only the perceived antiquity of the Sphinx. Why then did the scribe include such details, unless, of course, there was a foundation of truth to them?

The skeptics' bias against the text of the Inventory Stele mainly stems from a focus on the identity of the subjects and actors mentioned seen as anachronisms in the story. The skeptics' logic derives from this bias: If the actors are anachronistic, the story also cannot be true. If we took this logic to its end and substituted 

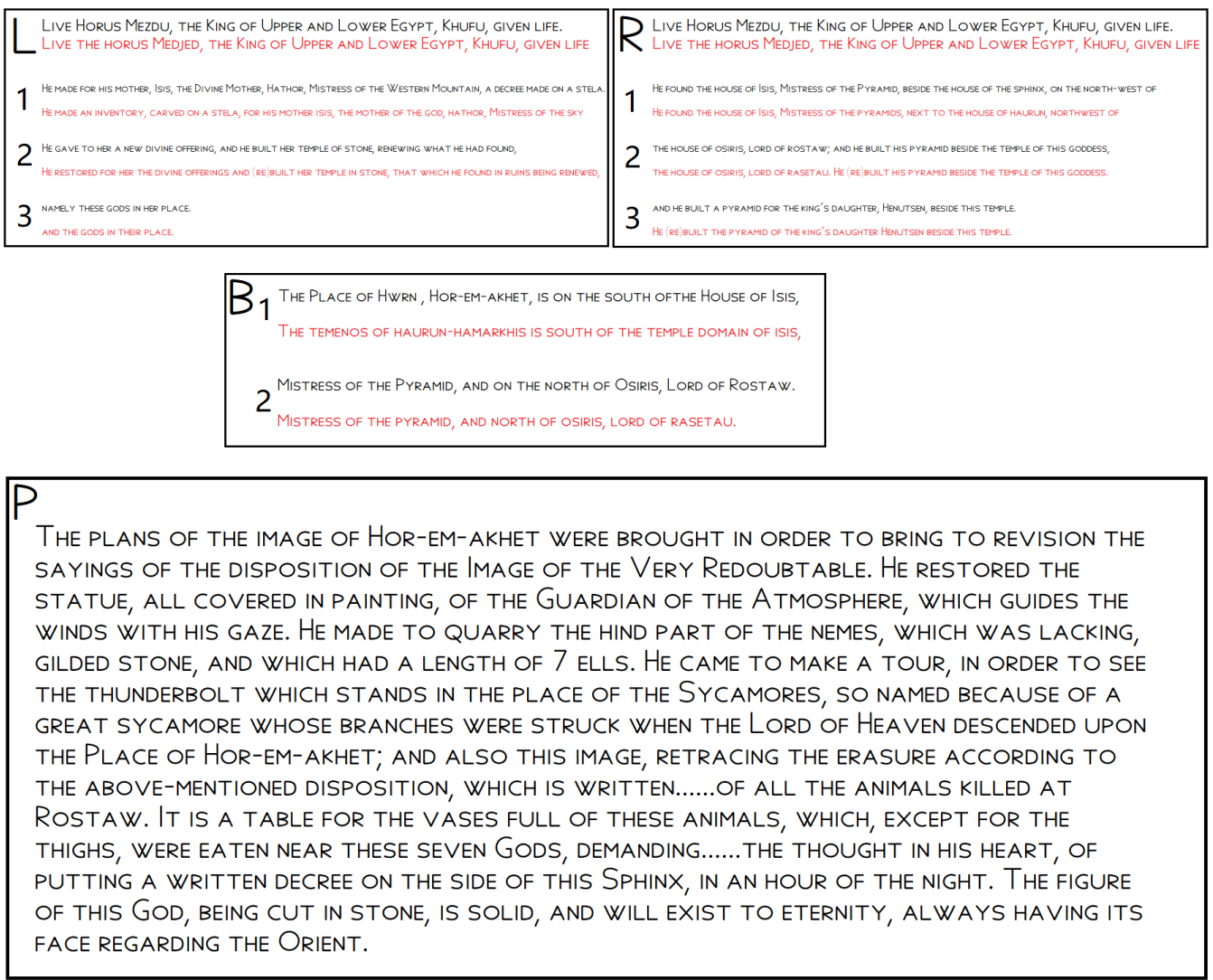

Figure 3. English translations of sectors L, R, B, and P of the inventory stele. Shown is black is the 1906 translation by James Henry Breasted (1906) and Christiane Zivie-Coche's 1991 translation is shown in red.
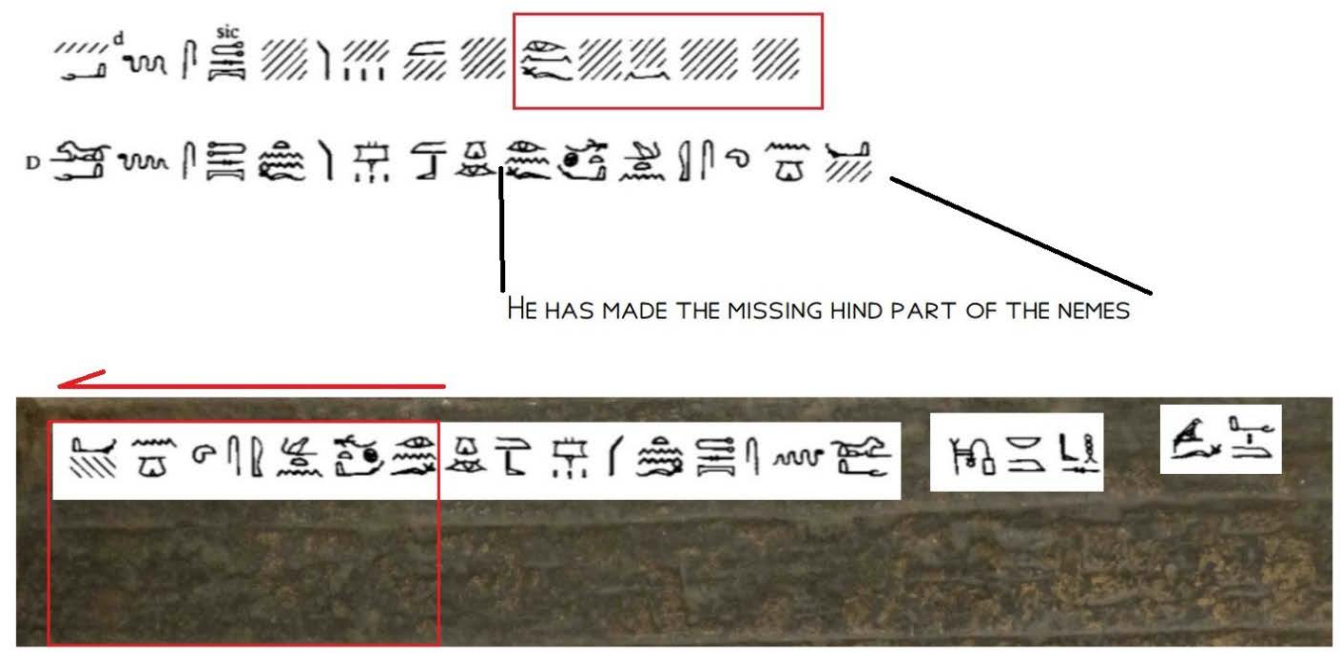

Figure 4. Excerpt from the leftmost aspect of the first row of the inscription on the pedestal, which is heavily damaged. The original text reads right to left, but Zivie-Coche wrote her and Georges Émile Jules Daressy's transcriptions (the latter is shown here) left to right, which we have reversed to align it in the correct sequence with the text on the pedestal. For each row of text, she transcribed what she could decipher and beneath (marked with "D") is an older version by Daressy presumably representing his transcription and interpretation of what was missing. The relevant phrase is framed in red. For comparison, we juxtaposed Daressy's " $D$ " version with the corresponding pedestal segment using more proximal hieroglyphs in the text which can be identified. To our eyes, however, the rest of the row is not currently interpretable from the recumbent lion symbol onwards. This means the entire phrase including the nemes may not be real, or it may have been damaged since Daressy studied the stele. Photo courtesy of Robert Schoch, March 2017; modified. 
Khafre for Khufu, Hathor for Isis, Andjety for Osiris, and Horakhty for Hurwn in the text, skeptics would more willingly accept the story built around Khafre as a historical record because it then would fit the prevailing narrative, the Khafre-Sphinx Theory. Yet, evidence is sparse at best that known or suspected historical frauds committed in ancient Egyptians texts involved fake names and fake events together. Rather, equally sparse evidence suggests instead that either names were embellished or the story, the former as propaganda and the latter as a gesture of reverence to the past, but not both. This is the first gap in the skeptics' logic.

To a modern-time skeptic, the choice of Khafre would lend a degree of credibility to the story not imparted by Khufu. The same would be true for the intended $26^{\text {th }}$ Dynasty audience of the stele. The stele's composer must have been aware of the nearby Dream Stele where Thutmose's circa 1400 B.C.E. Sphinx project is recorded. No mention of Khufu there has been preserved for us to explain his mention on the Inventory Stele. By contrast, traces of a cartouche believed to be of Khafre can be discerned on some renderings though the actual inscription on the Dream Stele is missing a substantial amount (Schoch \& Bauval, 2017). In other words, adherents of the Khafre-Sphinx theory-who, by definition, cannot possibly also accept the historical authenticity of the Inventory Stele's mention of the Great Sphinx in association with Khufu-expect the rest of the Egyptologists and the public at large to believe that the mention of Khafre on the New Kingdom Dream Stele is evidence that he built the Great Sphinx and, in direct contradiction, also expect us to believe that Saite-era priests of the nearby Temple of Isis would nevertheless be able to con their visitors into believing that the Sphinx already existed when Khufu came to Giza. This contradiction is the second gap in the skeptics' logic.

In this alleged "pious fraud" scenario, the composer would have been able to lean on the mention of Khafre on the Dream Stele to make the Inventory Stele more believable not with Khufu, but Khafre as the king who repaired the Sphinx and built his pyramid behind it. If we believe Herodotus' $5^{\text {th }}$ century B.C.E. account of Khufu in his "Histories", Khafre was probably also the more well-reputed king to serve as the actor in this alleged plot to commit pious fraud. Khafre enjoyed a sustained cult after his death (S.C.A., 2010). In other words, the ancient Giza visitors' perception of the antiquity of the Temple of Isis would have been better accomplished by placing Khafre into the story, just as a modern Egyptologist's perception of the stele's authenticity would be enhanced with him as the king who worked on the Sphinx, if s/he subscribed to the Khafre-Sphinx Theory. This is the third gap in the skeptics' logic.

Even if Khufu was originally mentioned on the Dream Stele and his cartouche was later hacked away by souvenir hunters or otherwise lost, he would have still been the worse choice of the two as part of a tale to feign age. For if some seasoned modern-time archeologists can feel a sense of conviction that the lay-out of Khafre's pyramid and Sphinx prove they were made together, then ancient 
tourists and donors to the Temple of Isis immediately north would have felt the same and believed such a tale.

Even if we ignore these three gaps and are asked to reject the Inventory Stele in its entirety as fraud because of the mention of Khufu, Isis, Osiris, and Hurwn, we are nevertheless forced to conclude that its creator wanted more than to merely make a Late Period Isis temple look as ancient as this king. S/he must have wanted to make the Sphinx look even older, even though this would have added little to the temple's perceived antiquity, the chief goal of the alleged fraudulent attribution. The temple sits next to Khufu's pyramid, not next to the Great Sphinx. This is the fourth gap in the logic of the critics.

These contradictions and the implausibility inherent in the skeptics' contention that the Inventory Stele must be a "pious fraud" are what prompted us to reexamine the text once more for any clues which may have been previously missed. We now proceed to address the individual elements of the critique, shown as statements in bold.

The Introduction of Khufu at the top of the Inventory Stele does not comport with the style used in the Old Kingdom but rather with that of the Late Period. The stele introduces Khufu first with his Horus name and then with his "Sedge and Bee" throne name. While it is correct that this sort of introduction is typical of the Late Period, for example the sarcophagus of Psammtik I (Figure 5), the same order of names can be seen presented in inscriptions of Khufu at Wadi Maghara and on two of Menkaure's triads from his valley temple. No fixed pattern of name order seems to have been established in the Old Kingdom as four samples of Menkaure's Valley Temple triad scenes demonstrate (Reisner, 1931: p. 46).

The mention of Khufu's wife Henutsen as a princess has never been seen in any inscription associated with her. The Temple of Isis extends across the mastaba of Khufu-Khaf, G7130-7140, indicating that the mastabas was demolished to make room for the expanding temple. However, reliefs remain showing Khufu-Khaf and his mother Henutsen (see Figure 6). In the relief shown, Henutsen is surrounded by her personal attributes, for example "mother of her beloved son" at the top, right to left. Marked in red, the attribute "nesu zat" can be discerned with the spelling Gardiner M23-X1-G39 (sedge-loaf-duck) from right to left which reads as "zat nesut" due to the customary honorific transposition and since small signs like X1 could be placed ahead and below a large sign like G39 even though the phonetic order is reverse (i.e. G39 first then X1); "zat" means "daughter" because the " $t$ " denotes feminine gender. The phrase therefore reads as "daughter of a king" or "princess" which can only refer to Henutsen.

The alternative arrangement of the three symbols into "nesut za", read "za nesut", is possible, but less likely because the overall lay-out of the presentation is that the textual attributions surround Henutsen, while Khufu-Khaf behind her is not surrounded by text making this the less probable interpretation. While it is possible that the phrase is a continuation from the above, i.e. "mother of her 


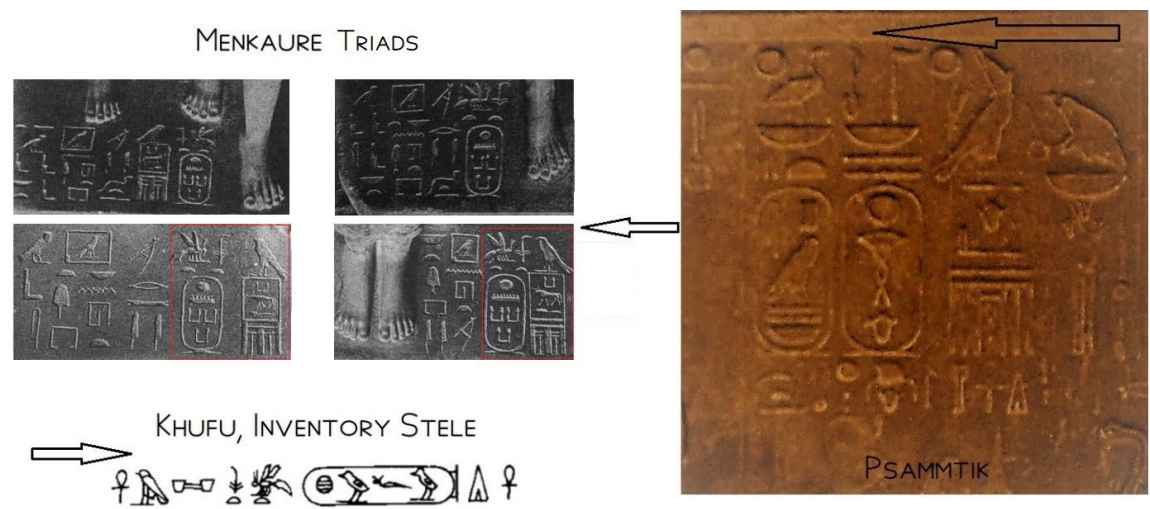

Figure 5. On the left are four different Old Kingdom pedestal inscriptions of Menkaure triad statues from his Valley Temple and on the right is an inscription of Late Period pharaoh Psammtik I. Marked in red, are two triads inscriptions showing the Horus name before the "Sedge and Bee" throne name. The arrow indicates the reading direction. The other two versions on top show the opposite order on the left and the throne name by itself on the right indicating that there was then no fixed pattern of displaying the king's name. Triad photos by Reisner (1931: p. 46), modified. Photo of Psammetichus I's sarcophagus courtesy of the British Museum under Attribution-NonCommercial-ShareAlike 4.0 International license; modified.

beloved son, the prince", the horizontal direction of the symbols facing right suggests that they are at the tail end of attributes, probably including Henutsen's name, now defaced, which once began in the right lower corner of the relief. In any event, the phrase is written in a similar manner as it is written on the Inventory Stele (Figure 7) and the same spelling and arrangement of symbols can be seen on a $2^{\text {nd }}$ Dynasty Slab Stele of princess Shepset-Ipet from Saqqara tomb S3477 (Brown University, n.d.). Yet, critics may insist that Henutsen's parents are not known and unless she was a daughter of Sneferu, the title could not possibly apply. But even this contention, that the princess title required a royal parent during the $4^{\text {th }}$ Dynasty, cannot be supported by available evidence. Both Hemiunu and Meresankh III carried the prince(ss) title even though neither parent in each case was either a king or a queen, only a prince (Junker, 1929: p. 152).

Henutsen's pyramid G1c was not part of Khufu's original plan for his pyramid field. The main argument brought forth to support this contention is that the southern edge of the perimeter of G1c does not line up with the southern edge of Khufu's pyramid. Instead, it lines up the southern wall of the double mastabas G7130-7140 and it is possible that Khafre built it (Verner, 2001: p. 212). However, neither G1b, nor Khufu's ka-pyramid G1d align with G1's perimeter and Menkaure's third queen pyramid G3c also aligns outside of that king's pyramid's perimeter while there is no indication that it was built by anyone other than Menkaure. Therefore, lack of a perimeter alignment is no indication of when a satellite pyramid was built in relation to the main pyramid in our opinion.

Since the Saite Temple of Isis was rebuilt over one of Khufu's east-field mastabas (G7130-7140; Khufu's son Khufu-Khaf), its original foundation 


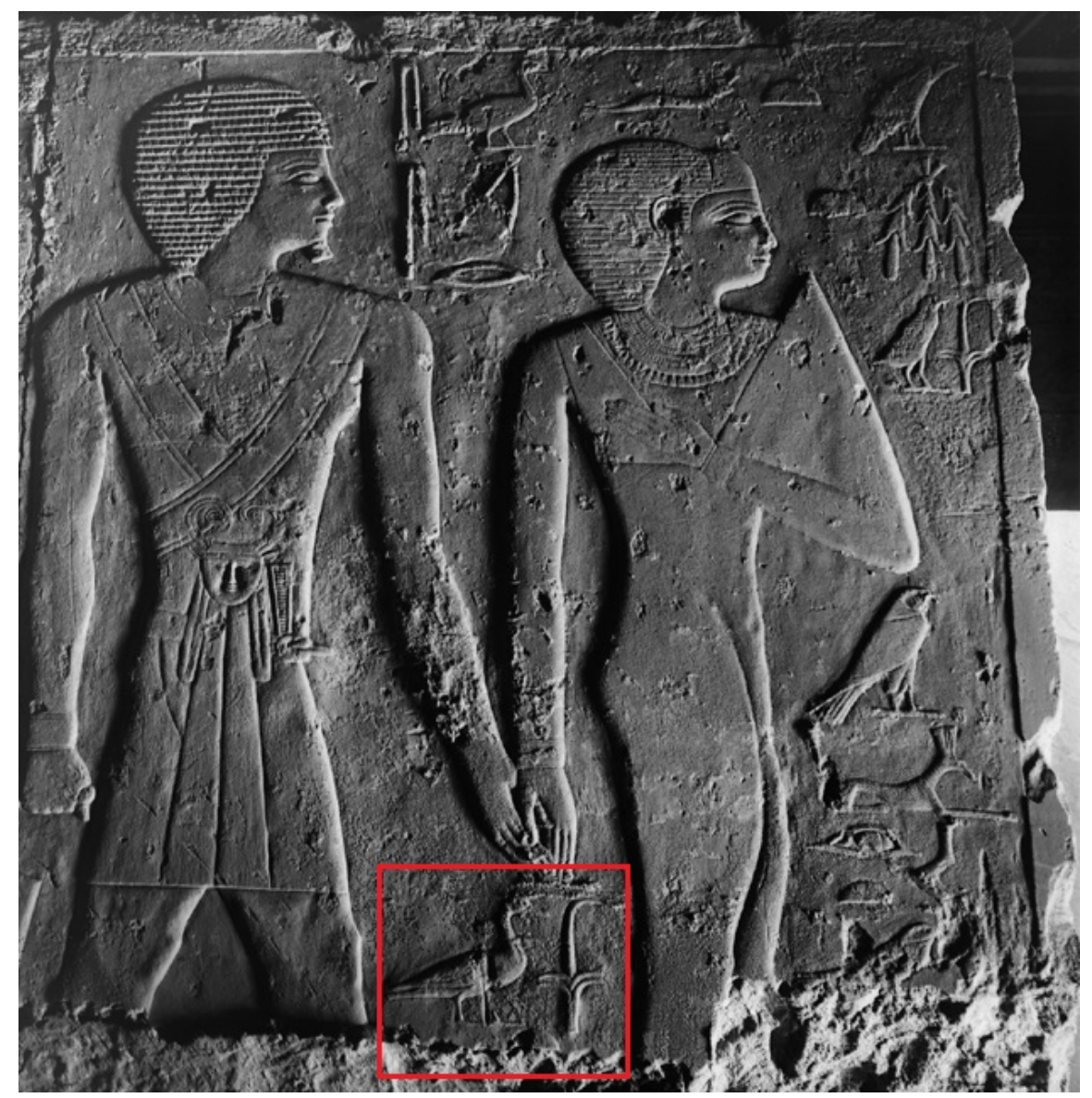

Figure 6. Tomb relief from the mastabas tomb G 7140, Khufu-Khaf I, chapel, room a (= published plan room $\mathrm{b}$, embrasure), $\mathrm{W}$ wall (= facade), $\mathrm{S}$ of entrance of room $\mathrm{b}$ (= published plan room a, inner chamber), relief (standing figures of Khufu-Khaf and his mother Henutsen), looking W. In red, the title "zat-nesu" can be seen which translates into "royal daughter" or "princess". The loaf symbol (X1) can be placed ahead and below for style, and honorific transposition places the royal sedge symbol in front, but the order of reading is duck-loaf-sedge. Photo courtesy of The Giza Project, Harvard University; modified.

cannot have existed before the time of Khufu. Let's review Selim Hassan's report of when the Temple of Isis encroached upon the nearby mastabas during its expansion in the Saite Period (Hassan, 1953: p. 112):

The temple was now extended eastwards across the wide street lying between the three small Pyramids on the west and a row of large, well-built mastabas on the east (PI. LI). Chambers were actually constructed in the cores of Mastabas Nos. 7130 and 7140 (see Plan: PI. LII), while the extreme eastern hall was built upon the roof of another mastaba. Moreover, practically all the stones of the masonry had been looted from buildings in the neighbourhood, and cut to the small size characteristic of this period.

We agree that Hassan's description of the Temple of Isis' expansion from G1c across mastabas G7130-G7140 is incompatible with the idea that Khufu built it, since they did not yet exist. However, a closer look at the relevant sector of the 

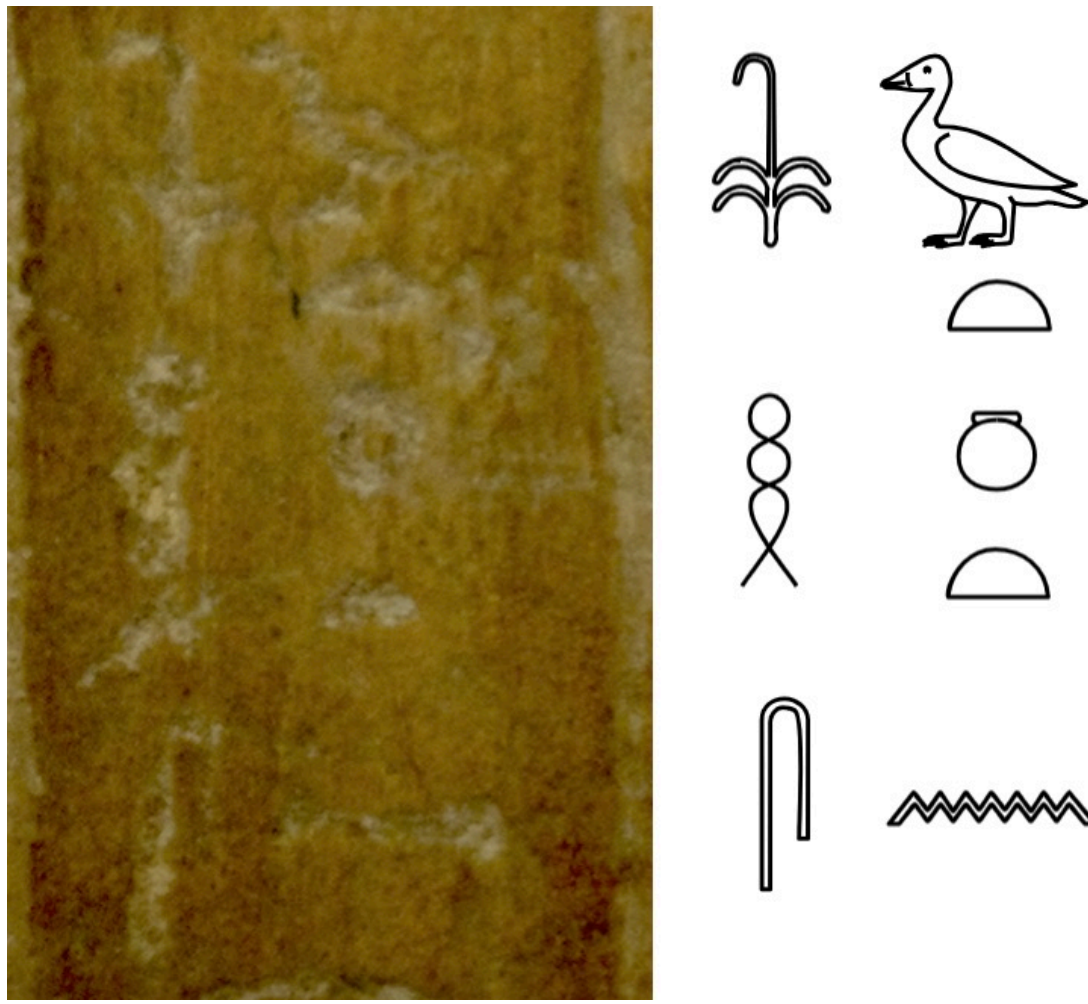

and

Figure 7. Original inscription and illustration thereof in sector $\mathbf{R}$ of the Inventory Stele showing the "zat-nesu", princess title at the top. The three symbols above "Henutsen" are read from left to right to below as Gardiner G39-M23-X1 (sedge-duck-loaf) with the words reversed due to honorific transposition (kings and gods were written first even when pronounced second). Photo courtesy of Robert Schoch, March 2017; modified.

Inventory Stele suggests that the temple's original location discovered by Khufu may have been elsewhere (Figure 8). The relevant text is framed in red and the words in question are further marked 1,2, and 3. In 1, the preposition Gardiner D21-AA16 "r-gs" translates as "with respect to it, side", i.e. "beside" or "next to", correctly so chosen by Breasted and Zivie-Coche, respectively. In her notes, however, Zivie-Coche concluded that the House of Isis and the House of Haurun were instead "nearby" each other and perhaps connected by an access road (Zivie-Coche, 1991: p. 223), which is the only way she could reconcile the fact that the Saite era Temple of Isis was not immediately next to the Sphinx temple, but next to Henutsen's pyramid G1c, some 330 meters away.

We disagree with this interpretation, because it is biased by the expectation that the original "House" was where the new "Temple" is and couldn't have referred to any other structure. We note here that the stele clearly distinguishes in sector $\mathbf{R}$ between a House (Gardiner O1) of Isis and a "Temple Enclosure (Gardiner O6) of this goddess". This bias creates the, we argue false, paradox cited by Hassan. We translate and literally interpret "r-gs" as "next to", in other words wall-to-wall. That means, the temple ruins Khufu found can only have been what traditional Egyptologists call the Valley Temple of Khafre, which evidence shows was in fact remodeled with a granite exterior over a much older limestone 


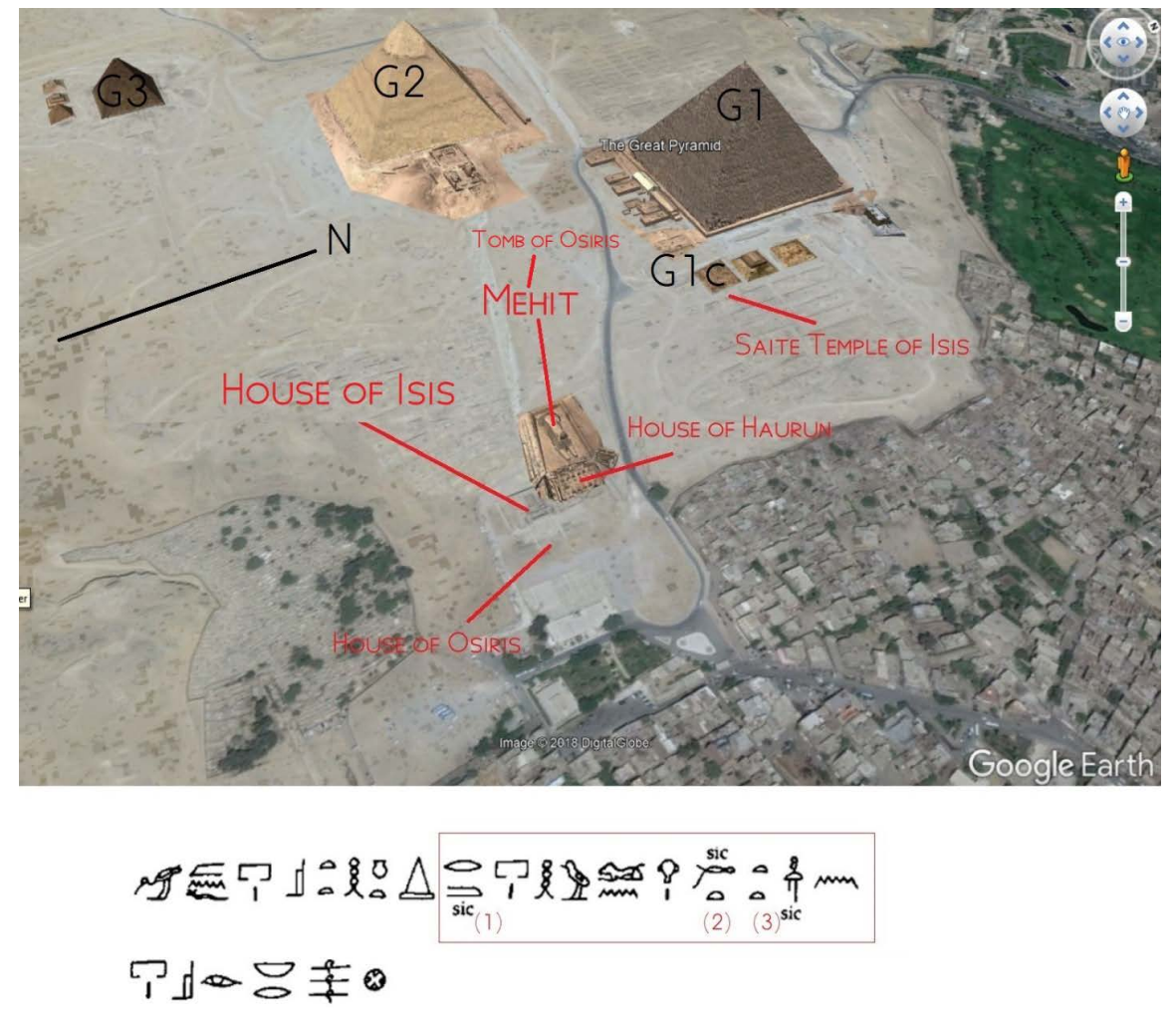

He has found the House of Isis, Mistress of the Pyramid, next to the House of Hurwin by MEHIT, (AND) WEST OF THE HOUSE OF OSIRIS, LORD OF ROSTAU.

Figure 8. Satellite aerial map (Google Earth; modified) is shown on top with structures marked as our translation of the relevant segment of text from the Inventory Stele suggests shown below. Words marked by 1,2, and 3 are discussed in the text. The hieroglyphic text framed in red corresponds to the English translation in red.

core (Schoch \& Bauval, 2017: pp. 251-259). We therefore consider the possibility that it was Khufu and not Khafre who remodeled the temple ruins attributed to Isis into the Valley Temple later claimed by Khafre. This would also support the idea of a master plan conceived by Khufu to develop the entire Giza Plateau and not just build his own pyramid (Bauval \& Gilbert, 1994).

Pertaining to (2) (Figure 8), while the word "meh" (Gardiner V22; pl. "mehw") was one way Old Egyptian referred to the cardinal direction "north" or "Lower Egypt" (Vygus, 2015: p. 2169; Pyramid Text 303, stanza 464a, Allen, 2013, Vol. III), the word "meh-t" (Gardiner V22-X1) is the name of the Old Kingdom Lioness Mehit, the consort of Anhur (Onuris). We have previously shown evidence that Mehit, at least since the time of $1^{\text {st }}$ Dynasty king Djer, was the name of the monument which was remodeled to become the Great Sphinx (Seyfzadeh et al., 2017). If Mehit in the text means "north", we are forced to extend this to "northwest" as per all previous interpretations. However, if this word referred to the lioness Mehit, specifically her statue at Giza, the meaning changes significantly. The lack of the lioness symbol determinative after the 
word "mh-t" on the stele does not help decide this because the name Isis is not further determined either to mark the word "jset" as pertaining to the goddess. A similar mix-up between the goddess Mehit and the word for the cardinal direction North may have occurred on the Stele of Wepemnefret in the second vertical column, where Helck translated "Priest of the Northern Horus" after "Servant of the Souls of Pe" (Helck, 1987: p. 284). We think this could be an error because of the adjectival gender mis-match. For Helck's translation to be correct the symbols on that stele should spell "hrw mhw", not "hrw mht" assuming Horus refers to a male god. The alternative reading is "Priest of Horus-Mehit", an allusion to the dual nature of this sun-associated deity as both lion and falcon. We were not surprised to find her mentioned together with Khufu, who would have known Mehit. We cannot fault James Henry Breasted and Christiane Zivie-Coche for missing this, but this underscores the need to reevaluate prior conclusions when new information comes to light.

In (3), both scholars may have been confused by the two loaf signs, X1/X1, placed in front of the feather-on-standard sign R14 instead of behind it, in which case the word means "west of" ("imentet"). Instead, it is possible that the scribe meant to use the word "twt" (image) and left out the weak vowel "w", which would not be unusual, certainly not an error. Then, "Mehit twt" is a direct genitive phrase, honorifically transposed, and means "image of Mehit" or simply "Mehit's image" and R14-N35 (water line sign) reads as "west of". However, this version is less likely, because in Sector $\mathbf{P}$ a different word is used to express "image".

Given the more accurate translations of (1)-(3), we can consider two corrected versions of the entire segment under examination: Either the phrase framed in red and on to the next line in Figure 8 reads "next to the house of Hurwn, by Mehit's image, west of the House of Osiris" or "next to the House of Hurwn, by Mehit, west of the House of Osiris". Both phrases are essentially identical in terms of locating the spot where Khufu found the House of Isis: Where the Valley Temple of Khafre now stands and not 330 meters uphill to the northwest where the Saite-era temple sits. The House of Osiris, therefore, was to the east of the Valley Temple (since the Isis temple is west of The House of Osiris, as per the text), i.e. it may have stood in front of the modern audience platform area where spectators nowadays sit to watch the Sound and Light Show.

We want to emphasize how these three problematic areas of text in this segment of sector $\mathbf{R}$, depending on how they are translated, may lead to a misplacement of the original Temple of Isis, which then leads one to further conclude that the Inventory Stele's location of the temple must be contrived based on this part of the critics' argument. This demonstrates that careful examination of the primary evidence is required and not opinions based on secondary evidence. Our interpretation of this part of the text makes the testable prediction that temple ruins existed or still lie under the area east of the two temples by the Great Sphinx. 
In the remainder of Sector $\mathbf{R}$, Khufu is said to have built two pyramids next to the Temple Enclosure of Isis, not the House of Isis, which we locate immediately next to the other two "houses", those of Hurwn and Osiris. This indicates that there were two structures dedicated to Isis, a house by the Great Sphinx and a temple enclosure up higher on the hill top, now the site of G1c and the Saite era Temple of Isis. There is evidence that "hwt" estates had a "mrt" shrine (e.g. a shrine inside a house) separate from the "hwt" temple of the estate (see below), a more substantial structure. It is on or over the grounds of this original temple enclosure that we believe the first row of mastabas including G7130-7140 must have been built by Khufu's relatives, which, in turn, were later encroached upon by the New Kingdom and/or Late Period rebuilds of that temple.

We now proceed to reconcile the description given in Sector B with the foregoing analysis. A temenos, marked in red in B line 1 (Figure 9), is a sacred lot of open air land or a precinct like a temple courtyard for example, but not a building or place (i.e. Breasted's translation). The text informs us that this sacred precinct of Hurwn Horemakhet is south of the House of Isis (which we have located to the site of the Valley Temple). This area south of the House of Isis (Valley Temple) happens to be land, now a graveyard, shaded by a few Sycamore trees just south of the Great Sphinx, to which the text in P refers.

At this point after "Isis", both Breasted and Zivie-Coche translate through into the next line (B line 2) under the presumption that Isis is again apposed with the epithet "Mistress of the Pyramid" despite the fact that here this phrase is spelled Gardiner W10-X1-O24 while the spelling of the phrase in the earlier instance ( $R$ line 1) is V28-W10-X1-O24 (Figure 9). We disagree with this interpretation and propose that $\mathrm{W} 10-\mathrm{X} 1-\mathrm{O} 24$ not only begins a new sentence but has a different meaning from "Mistress of the Pyramid". In R line 1 the V28 symbol for the sound " $h$ " is not a second " $h$ " meant to be pronounced, but a phonetic complement which was a common reading aid Egyptian scribes of all eras used to clarify the pronunciation of an adjacent biliteral or triliteral symbol. V28 clarifies that W10 should be pronounced as the triliteral "hnw" and consequently the whole word W10-X1 as "hnwt" ("mistress") in that instance. This phonetic complement is missing in the second instance of the word in $\mathbf{B}$, line 2. Interestingly, both Selim Hassan (Hassan, 1953: p. 111) and Christiane Zivie-Coche (Zivie-Coche, 1991: pp. 224-225) considered that this epithet might be a word play on Khufu's wife Henutsen, but they failed to recognize the possibility that the two different spellings may indicate two different pronunciations of the cup symbol "W10" and thus two different words altogether. We also considered that a word play may be hiding in this phrase; however, not a play on Henutsen, but on Osiris, Isis' consort.

We therefore searched Vygus' dictionary (Vygus, 2015) for alternatives and found that the phonetic value of W10, besides "hnw" can also be identical to the arm symbol "D36" (Figure 10). Then, the pronunciation of W10-X1 is "aat" and this means "house" or "bowl", not mistress. We therefore propose that the word 


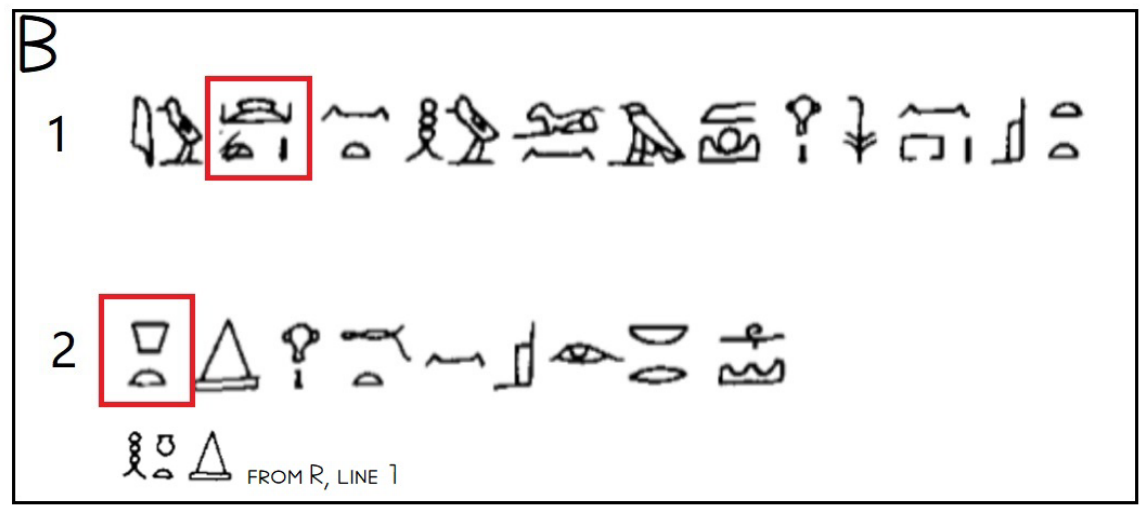

$$
\begin{aligned}
& \text { B1 The Place of Hwrn, HOR-EM-AKHEt, IS ON THE SOUth OFTHE HOUSE Of ISIS, } \\
& \text { THE TEMENOS OF HAURUN-HAMARKHIS IS SOUTH OF THE TEMPLE DOMAIN OF ISIS, } \\
& 2 \text { Mistress of the Pyramid, AND on the nORTh of Osiris, LORD OF ROSTAW. }
\end{aligned}
$$

Figure 9. Hieroglyphic and English text from sector B of the inventory stele. Marked in red are the words "temenos" and "mistress" which are discussed in the text. Color-coded English translations are by Breasted (black) and Zivie-Coche (red). To compare the two spelling versions of "Mistress", the one from $\mathbf{R}$ is shown beneath the one from $\mathbf{B}$ illustrated here.

spelled W10-X1-O24 in B, line 2, should be translated as "tomb (chamber)" and not as "Mistress of the Pyramid". Then, the rest of the line also makes more sense because the direction given is not with respect to the god "Osiris, Lord of Rostau (Rostaw, Rasetau)", which implies the strange notion that the god himself was visible on the plateau, but with respect to his tomb. In other words, we propose the following translation: "The tomb (chamber) is by Mehit (i.e. the Sphinx) belonging to Osiris, Lord of Rostau" reading N35 as the nisbe "nj" ("belonging").

The meaning of this statement is now clearer: The tomb of Osiris is below where Howard Vyse found "Campbell's Tomb" in 1837, a short distance west from the Great Sphinx (Vyse, 1840, Vol. 1, p. 216; marked in Figure 8). And in fact, Vyse discovered an arched edifice on the first level into which a W10-like cup symbol was inlaid in a manner reminiscent of the "Htp-Re" symbols built into the base of the obelisk of Niuserre's sun temple at Abusir (Figure 11). The lid of the sarcophagus in the submersed basin on the third level of Campbell's tomb is also shaped like an inverted "W10" symbol. The allusion to the holy vessel, i.e. a sarcophagus in which the god rested sealed with a lid symbolizing Osiris' mother Nut, the goddess of the sky, is compelling as is the word play between the word mistress and the goddess Nut (“ $[\mathrm{H}] \mathrm{Nwt}$ "). A discussion on the possible age of the different levels of Campbell's Tomb is beyond the scope of this paper, but the suggestion is that the lowermost level dates to the Old Kingdom or earlier. 


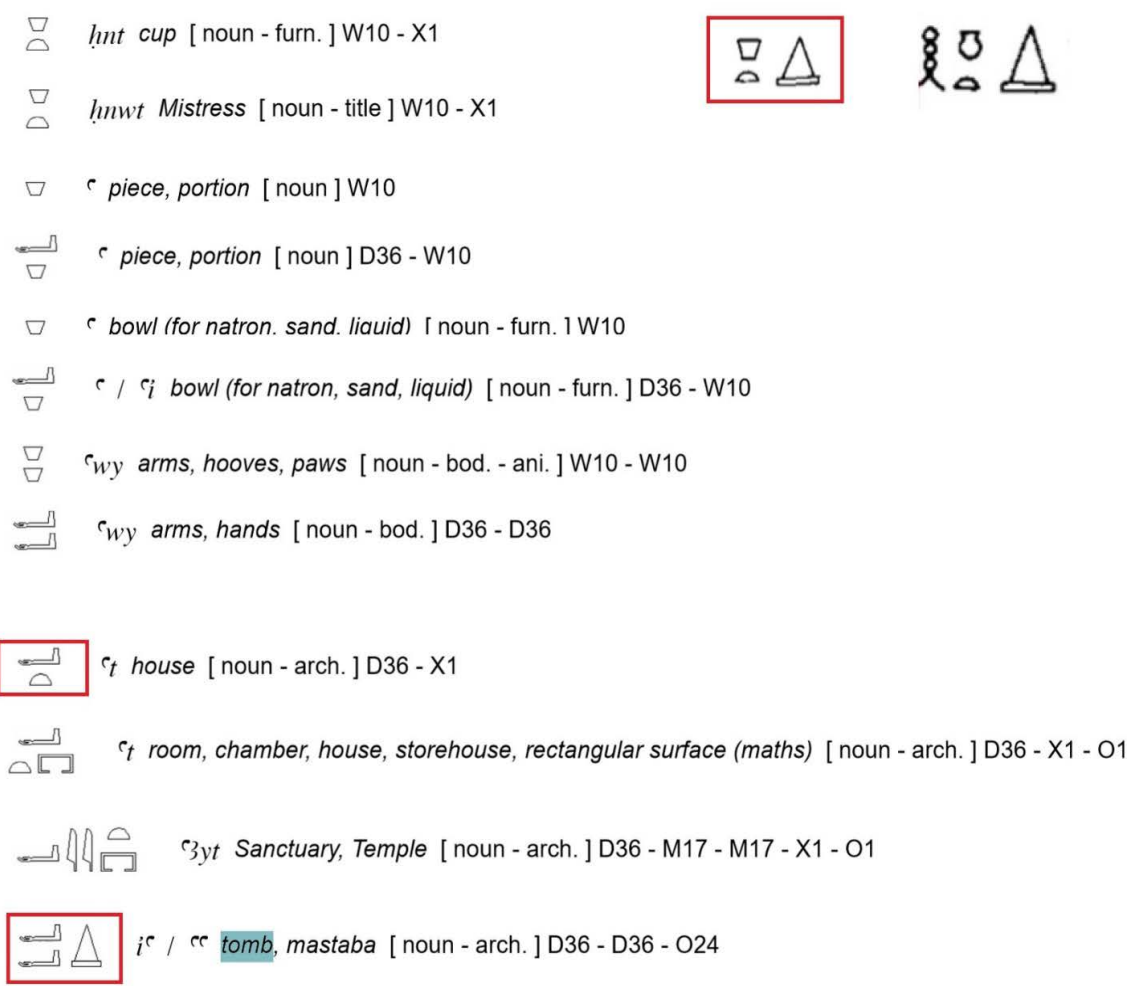

Figure 10. The phonetic equivalence between hieroglyph W10 and D36 is shown (Vygus, 2015). As a result, the word interpreted as "Hnwt" by Henry Breasted and Christiane Zivie-Coche can also be interpreted as "aat", which means house or bowl. When determined with the pyramid symbol Gardiner O24, i.e. unlike in the two authors' version where it functions as the word for pyramid and not as a determinative, it is probable that "aat" meant tomb chamber.
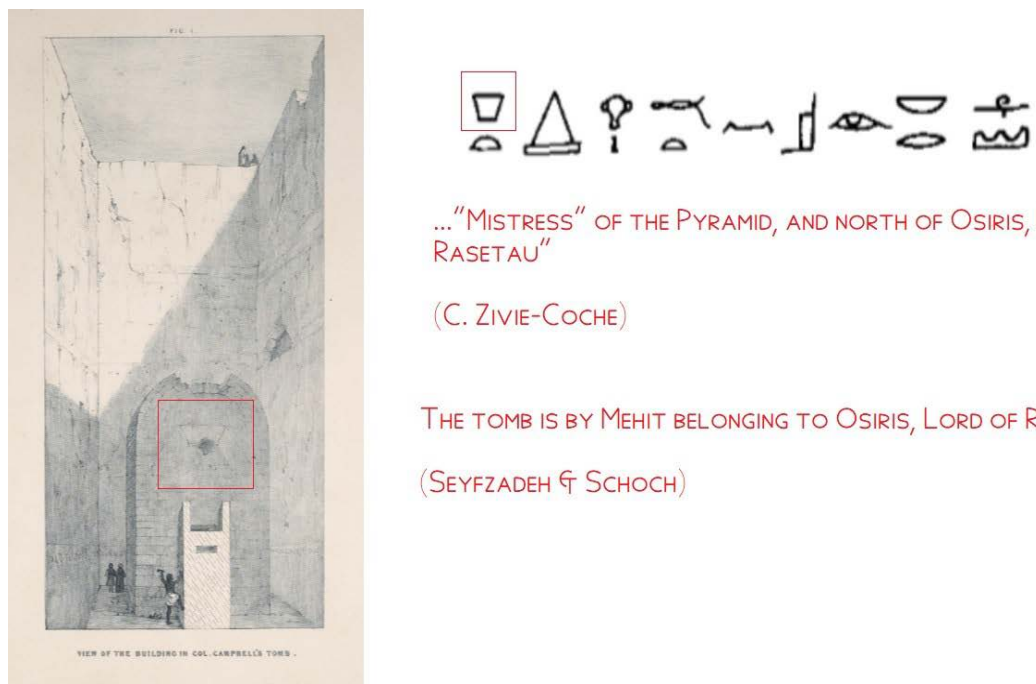

..."MISTRESS" OF THE PYRAMID, AND NORTH OF OSIRIS, LORD OF RASETAU"

(C. ZIVIE-COCHE)

THE TOMB IS BY MEHIT BELongING TO OSIRIS, LORD OF ROSTAU

(SEYFZADEH $G$ SCHOCH)

Figure 11. The "cup" symbol Gardiner W10 in Christiane Zivie-Coche's translation of B, line 2, can be seen incorporated into the arched edifice on level 1 of the "Tomb of Osiris", also called Campbell's Tomb, shown in this drawing by Howard Vyse's companion John Shae Perring (Vyse, 1840, Vol. 1, p. 216; modified). Our translation of the phrase is shown below that of Zivie-Coche. 
There is no documented worship of Isis or Osiris during the time of Khufu. This, arguably, is the most devastating and damning observation which turned the Egyptological establishment against the Inventory Stele. But two hundred years after Khufu, Osiris is mentioned over one hundred times in the Pyramid Texts of Unis and Isis at least nine times. By contrast, Khnum is mentioned once in the Pyramid Texts of Unis, even though Khufu evidently knew his own patron god. By that metric, he must have known Osiris too, but two hundred years is still a long-time span across which to reach back with confidence.

However, evidence of Osiris' celestial footprint, Orion, is embedded in the architecture of Khufu's pyramid (Bauval \& Gilbert, 1994; Schoch \& Bauval, 2017). The Queen and King chambers' south shafts accurately point towards those areas in the night sky where the stars Sirius and Alnitak could be seen at their meridian transits when Khufu was alive. Further corroborating this theme is the alignment of the three Giza pyramids with Orion's belt stars suggesting a premeditated master plan inspired by the Osirian resurrection theme (Bauval \& Gilbert, 1994). This Pyramids-Orion alignment has been astronomically verified (Orofino \& Bernardini, 2016). Orion, in turn, can be proven to be the celestial Osiris in the Pyramid Texts (Krauss, 1997: pp. 165-173; Allen, 2005: p. 37; text in brackets added):

[Speaking to Unis]

In your identity of the one in Orion, with your season at the sky and your season at the earth: Osiris, turn your face and look at this Unis, your seed that came forth from you active: he will live and this Unis will live, he will [not] die and this Unis will not die, ...

The astronomical architecture of the shafts in Khufu's pyramid together with the alignment of the three pyramids supports the idea that Khufu and his presumed architect Hemiunu knew Isis and Osiris. Further evidence that Osiris was recognized even before the time of Khufu is the depiction of Sneferu at the Sinai Wadi Maghara wearing a crown with two plume feathers and ram horns, two of three identifying marks of Osiris' "Atef" crown ${ }^{2}$ also seen in the throne relief of Niuserre (Figure 12) and on a relief from Userkaf's mortuary temple (Cairo Museum). Another hint of the Osiris cult can already be gleaned from a new burial theme evident in the early $4^{\text {th }}$ Dynasty when the dead were mummified and placed inside the coffin in a statue-like, extended position departing from the prior custom of placing a non-mummified corpse in the contracted, "fetal" position (Aidan Dodson, personal communication; Petrie, 1892: p.21).

Examining the hieroglyphic text of the Inventory Stele, the uncommon spelling of the name "Isis" stands out. There are four potential occurrences (Figure 13): Three are spelled Q1-X1-X1 (throne-loaf-loaf) and one is spelled $\mathrm{Q} 1-\mathrm{X} 1-\mathrm{O} 1$. The latter can also mean "places" and it is this translation which makes more sense in sector $\mathbf{L}$ on line 3: "He has found those gods in their places" which is also how both Breasted and Zivie-Coche translated that word. The ${ }^{2}$ Two ostrich feathers, the "hedjet" crown, and, variably, the straight twisted ram horns of Khnum. 

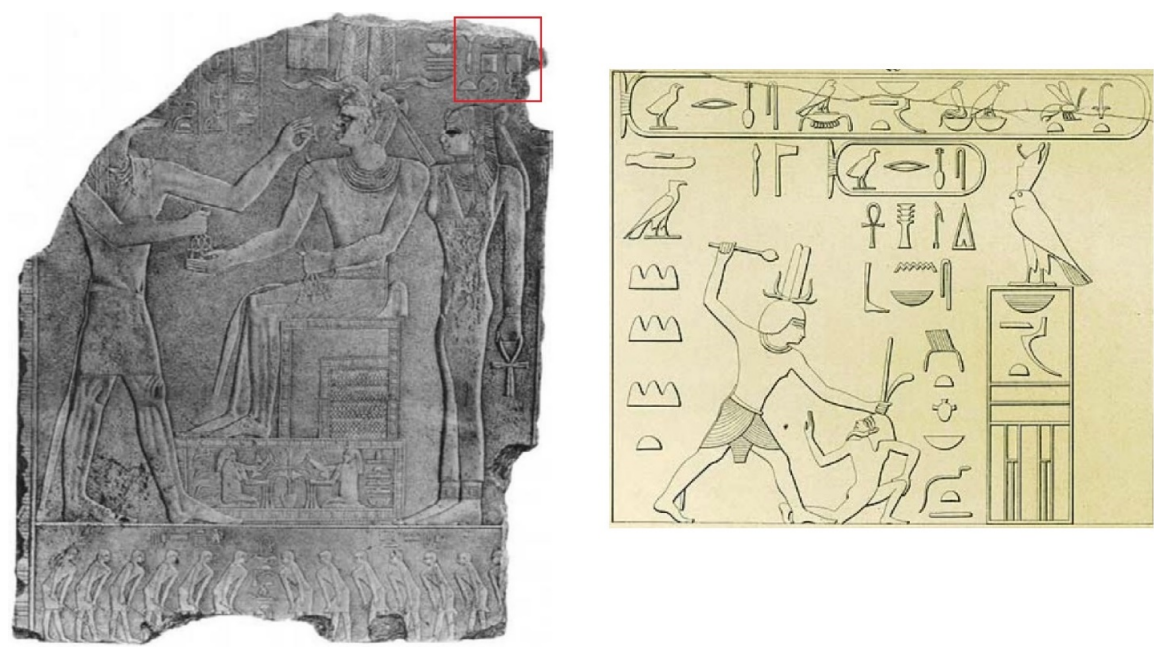

Figure 12. On the left, throne scene relief showing Niuserre with the Osirian crown. Wadjet, her name framed in red, from Buto (Dep and Pe) standing behind him. On the right, rock relief from Wadi Maghara on the Sinai Peninsula showing Sneferu wearing the same crown. Niuserre throne scene from Das Grabdenkmal des Königs Ne-user-re' by Ludwig Borchardt, 1907. Sneferu relief Illustration by Richard Lepsius, Tafelwerke, Abtheilung II, Band III, Seite 2. Digital reproduction with permission of Universitäts-und Landesbibliothek Sachsen-Anhalt (http://edoc3.bibliothek.uni-halle.de/lepsius/start.html).

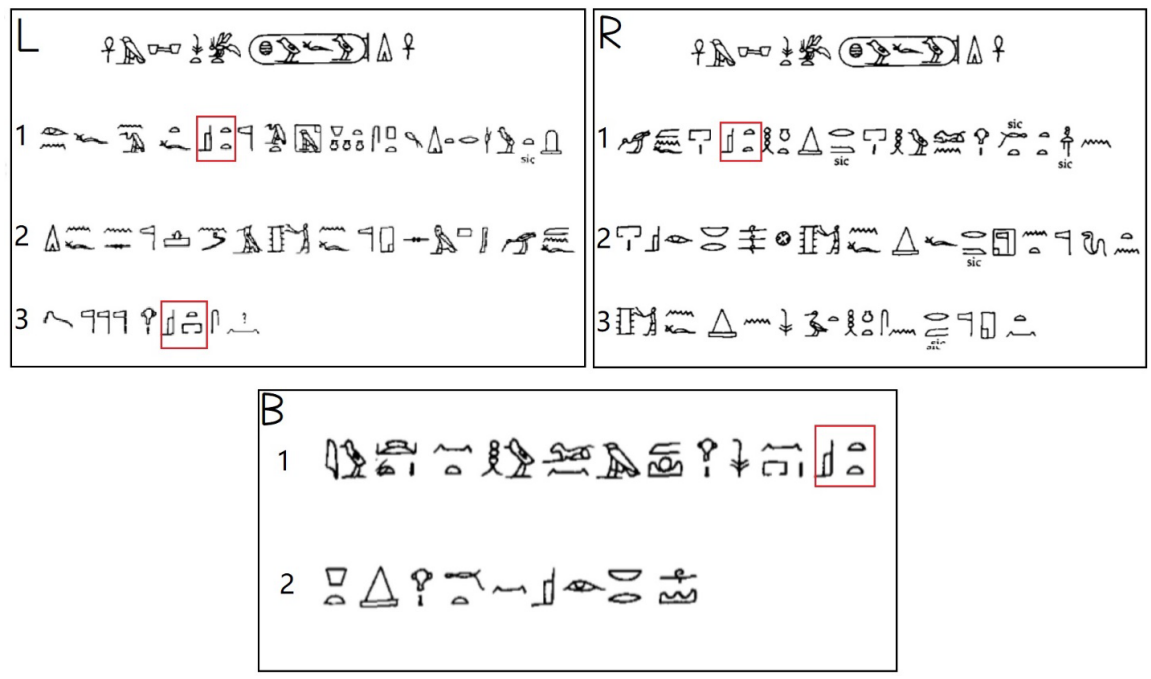

Figure 13. There are four total occurrences of the word "Isis" according to the translations by Breasted and Zivie-Coche in the text of the Inventory Stele, all marked in red; three spelled Gardiner Q1-X1-X1 (throne-loaf-loaf) and one spelled Q1-X1 with determinative sign $\mathrm{O} 1$. Sector $\mathbf{P}$ does not mention either Isis or Osiris.

name "Isis" in the remaining three occurrences on the stele is spelled in an uncommon way not often seen in either Old, Middle, or Late Egyptian, with two "X1"s, i.e. probably pronounced "Iset", but with a phonetic complement, or less likely "Isetet" with both t's pronounced. Is it possible a priestly scribe who meant to deceive private or official donors would use an uncommon spelling of the name of Isis to draw attention to this alleged pretense? 
We believe this is another gap in the skeptics' logic. The alternative explanation is that the original name of the goddess written on the previous version of this text copied by the scribe had a different name more relevant to the time of king Khufu and the scribe adapted it to his time not by adding an extra X1 sign, but by replacing the first letter with the throne sign Q1. That then could be the extent of "cheating".

But what could have been the name of the goddess in the original source text which was changed to become "Iset"? The most likely explanation is the goddess Satis/Satet, the known consort of Khnum, Khufu's patron god from Upper Egypt's Elephantine Island. Satet is documented at least as far back as the time of Djoser, i.e. over one hundred years before Khufu lived (Wilkinson, 2003: p. 165). This goddess had a proven association with Sirius. Beginning in predynastic times, seven known rebuilds of her island temple spanning a time of at least two thousand years tracked this star's precession and proper motion (Wells, 1985).

The original first hieroglyph in Satet's name, Gardiner S22, has a phonetic value like Q1, i.e. "st/sat", and was used in the Pyramid Texts, for example Pepi I 439 (Figure 14), where her name is given the added determinative Gardiner N25. N25 was one way to denote "west" (Vygus, 2015: p. 568). It is possible that S22 originated from the asterism formed by the stars near Sirius, today known as Canis major (Figure 15). S22 was substituted with Gardiner F29 in later spellings, which also encodes the sound "st" (Figure 16). Evidently, the spelling of her name underwent two documented revisions.

The epithet "Mistress of the Pyramid" applied to Satet, because at the end of the $3^{\text {rd }}$ Dynasty Huni or Nebka built a granite small step-pyramid near her temple (Dreyer \& Kaiser, 1980) which Khufu would have visited because he likely founded an estate there (Friedmann, 2015: p. 29). In other words, before Khufuconducted any work at Giza, he would have been well familiar with a goddess whose temple lay next to a pyramid built by an ancestor, who was associated with the star Sirius and who was the consort of Khufu's patron Khnum. In addition, Khufu would have known that his presumed father Sneferu had already

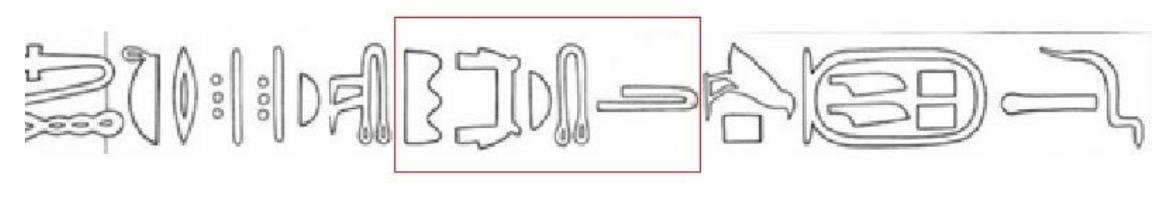

$$
\text { SATET, PT } 439 \text { (PEPI) }
$$

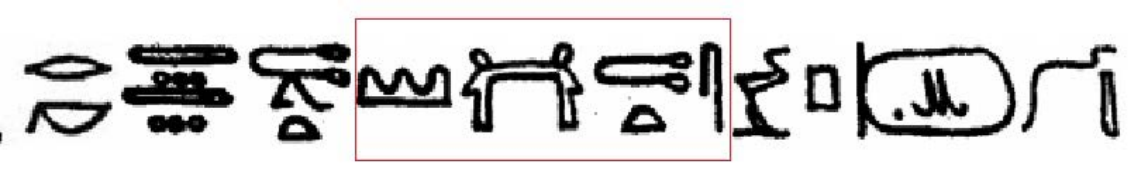

Figure 14. Excerpt from Pyramid Text 439, Pepi, showing the spelling of "Satet" including the determinative N25 at the end denoting "foreign land" and "west" (Allen, 2013, Vol. IV). 


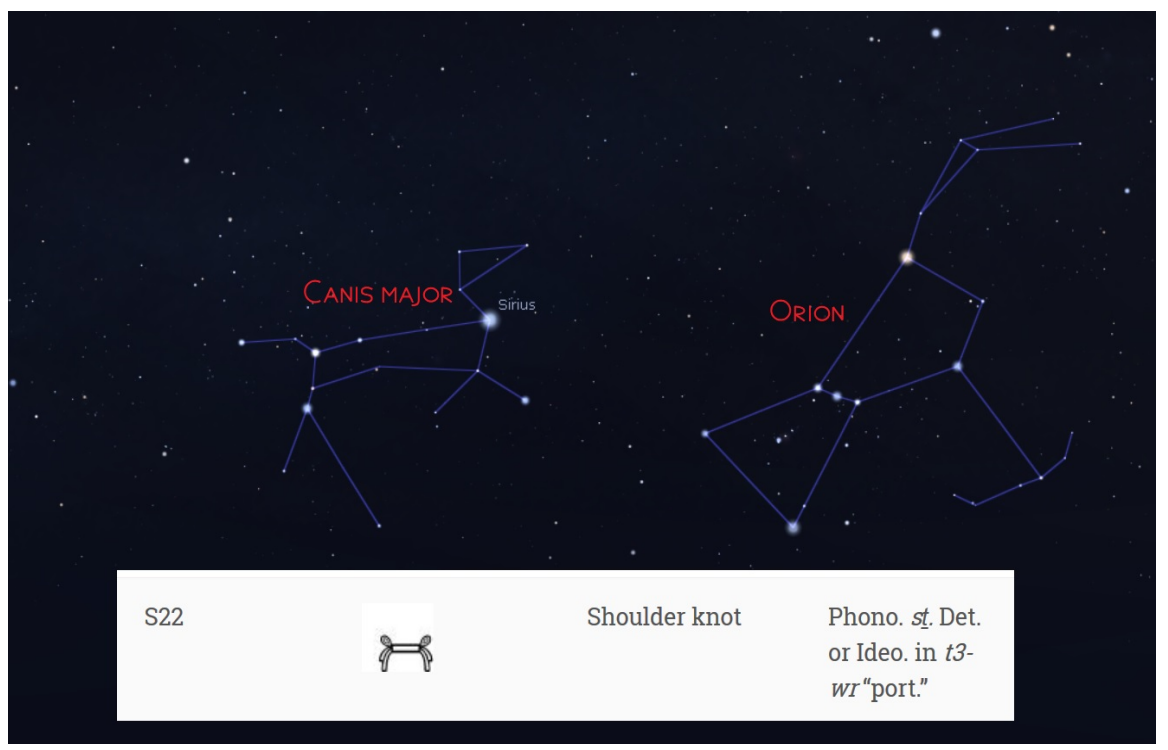

Figure 15. Shown here are the constellations we know as Canis major and Orion, the former incorporating Sirius. The similarity between Canis major and the shoulder knot symbol raises the possibility that the imagined stick figure made up by the stars inspired this hieroglyph and its use in the name of Satet associated with Sirius. Star illustration by Stellarium; dictionary excerpt by Vygus (2015); graphic by Manu Seyfzadeh.

established six important estates marked with small step-pyramids (Friedmann, 2015: p. 37; Willems, 2014: p. 20-21). The same general theme, the building of a pyramid and temple next to an economically important estate dedicated to a female deity, appears in the Inventory Stele. This theme is not anachronistic to the Old Kingdom. Such story elements would however be anachronistic to the Late Period when the Inventory Stele was made making it less likely that they were invented.

In short, we believe that while the Late Period scribe of the Inventory Stele may have taken the liberty to change Satet to Isis, this change is much more harmless than the stele's critics have alleged because it does not jeopardize the body of content of the stele's text which appears entirely authentic in its main story line. We do not believe the evidence shows that the change was made to feign antiquity. The Q1-X1-X1 spelling used may have been in use on the Giza Plateau, but was otherwise unusual. On Giza's south side is the Saite-era tomb of Police Chief Thery at Gebel Qibli, also dated to the $26^{\text {th }}$ Dynasty. There, the name "Isis" is spelled exactly as on the Inventory Stele (e.g. central hall, eastern wall, southern section; El-Sadeek, 1984: p. 45) and as it is spelled on the north wall of Chapel A in the Temple of Isis (El-Sadeek, 1984: p. 109). Elsewhere, however, the pattern is different.

Joanna Labudek (2010) has compiled a list of $26^{\text {th }}$ Dynasty Steles from the Serapeum at Saqqara, a short distance south of Giza, which shows that on most privately dedicated steles (Labudek's categories A-D, p. 13) in which Isis is mentioned the spelling is different from Q1-X1-X1. Our count based on her 


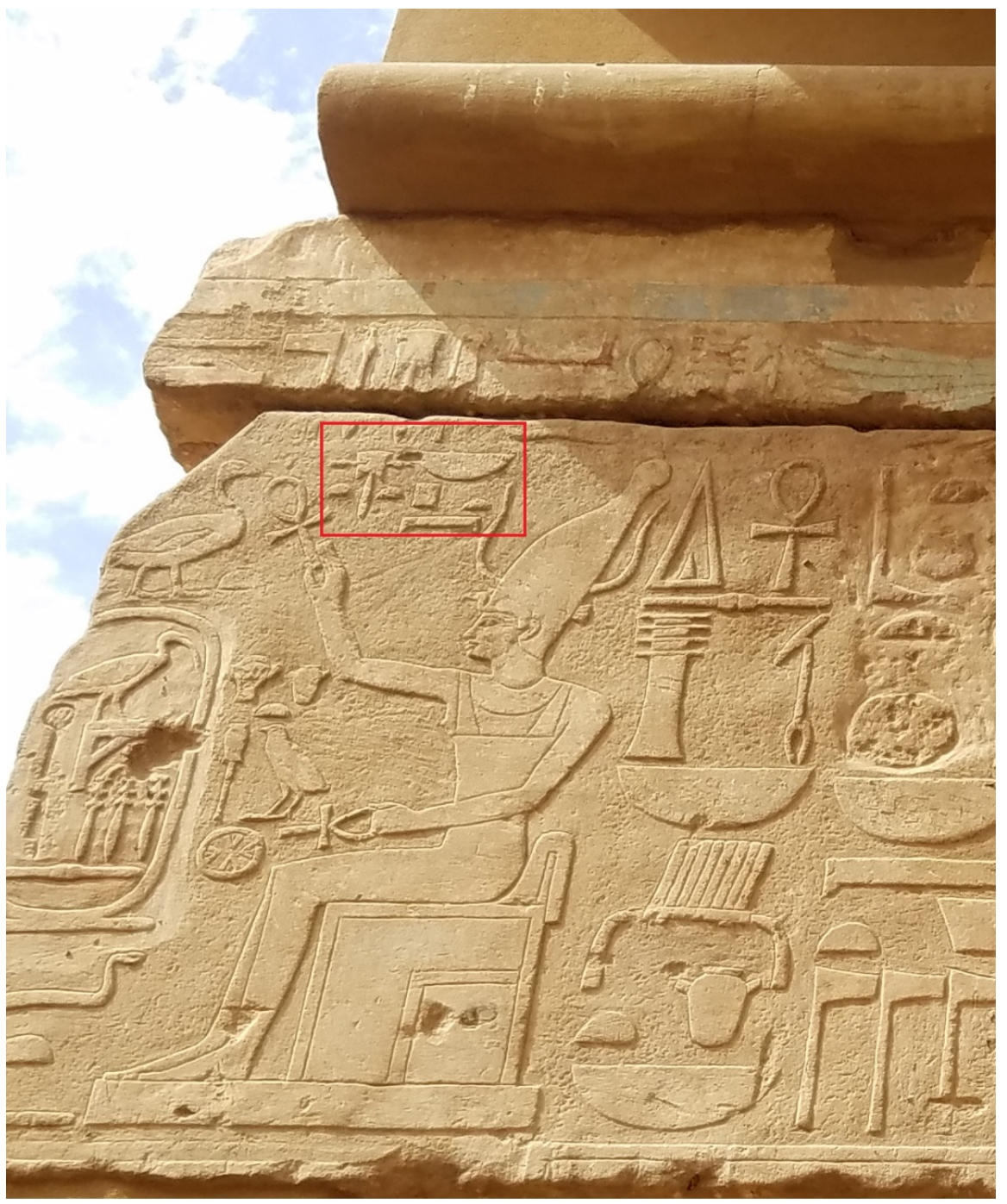

Figure 16. Relief showing Satet on an architrave of her temple on Elephantine Island. Shown in red is her name spelled Gardiner F29-X1-X1 with her epithet "Mistress of the Sky". Photo courtesy of Manu Seyfzadeh, Feb. 2017; modified.

inventory listed (Labudek, 2010: pp. 116-434) reveals a ratio of approximately 1-to-5 Q1-X1-X1's per all other spellings. The two exceptions were from a time after Psammtik I's $20^{\text {th }}$ year on the throne. On royal steles, however, the $\mathrm{Q} 1-\mathrm{X} 1-\mathrm{X} 1$ spelling predominates. Our survey of this sample of steles from the $26^{\text {th }}$ Dynasty suggests that the Q1-X1-X1 spelling was peculiar to Giza and the steles produced by the royal scribes, and not typically used on steles commissioned by private Egyptians. Besides, the Q1-X1-X1 spelling was not typical of prior eras. Therefore, use of the relatively uncommon Q1-X1-X1 spelling on the Inventory Stele argues against an intent to inconspicuously "age" the text. An alternative motive to changing the name of Satet to Isis could have been to make the stele look royal or official since the use of that spelling seems to have been a signature feature of the royal house scribes.

Even if either explanation is incorrect, the origin of the word "Iset" (Isis) can 
be traced back to a time long before the Pyramid Texts. The Q1 throne hieroglyph belongs to the oldest known alphabet in the world (Dreyer, 1999). It was found carved into ivory tags from "Scorpion's" Tomb UJ and a two-symbol word containing it has been firmly interpreted as "Ba-set" (Bubastis), a city in Egypt's delta (Kahl, 2003: p. 122). The same symbol reappears in the archeological record on tags attached to oil jars found in the tombs of $1^{\text {st }}$ Dynasty kings Narmer through Den (Helck, 1987: p. 173). There, it is part of a recurrent set of three symbols (falcon, throne, hobble) which Wolfgang Helck interpreted to mean "Baumgarten des Horus", i.e., "Horus' Tree garden" (Figure 17; Helck, 1987: pp. 171-172). This suggests that the Buto word an Egyptian would have pronounced "Hor-Iset" and translated as "Horus' Tree Garden" had long been used to designate an oil trading or processing compound likely located in Lower Egypt's Delta. Evidence that "Horus' Tree Garden" was in fact such an estate is further supported by the heretofore unrecognized connection between the untranslated symbol "Nj3u" (Ibex Head; Helck, 1987: pp. 172-173) and the word for the farm of a royal "hwt" estate, "njut" (Friedmann, 2015: p. 26). We see here
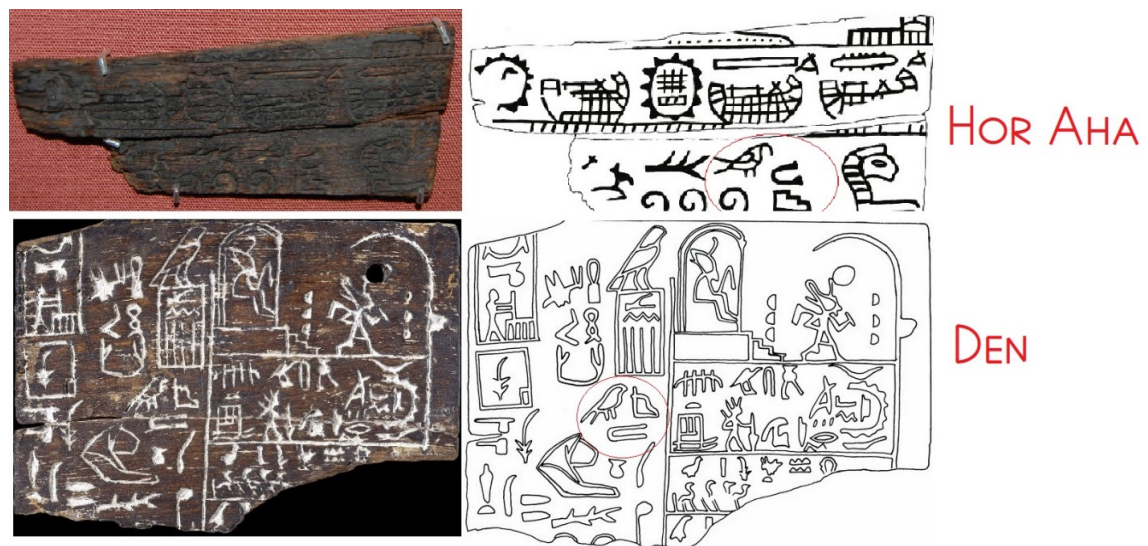

\section{DEN}
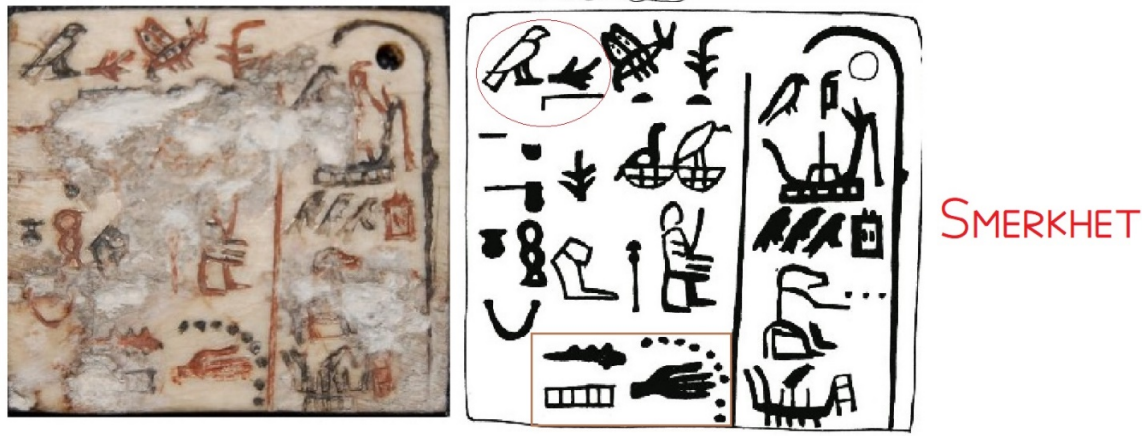

Figure 17. The throne symbol as part of the "Buto set" (see red circles) appeared on wooden oil tags used during the reigns of Horus Aha and Horus Den and was replaced by Egyptian letters on ivory tags which translate as "Horus' Tree Garden". The coiled rope symbol inside the red circle on the top right illustration is not part of the set. The possible pronunciation of the triad was "Hor-Iset". The oil appears to have been Cedar oil used for hand purification as shown in the right lower pane marked by the brown rectangle. Photos and illustrations courtesy of the British Museum under Attribution-NonCommercial-ShareAlike 4.0 International license; modified. 
a recurrent theme from our earlier investigation of Mehit (Seyfzadeh et al., 2017): Buto symbols, like the recumbent lioness with bent rods emanating from her back, were logograms while Egyptian hieroglyphs are predominantly phonograms. Consequently, the hobble (used to restrain farm animals) may have designated a "farm" in the Delta and the throne/steps may have symbolized the temple built by that farm together forming an estate.

The loop can now be closed by observing that the spelling of Bubastis, i.e. Baset, later changed to include the symbol for oil, Gardiner W1. To sum up, the origin of the Egyptian name for Isis, "Iset", can be traced to an oil and salve-processing facility in the Delta city of Bubastis, whose patron goddess could have been "Iset" and which delivered oil products to Egyptian kings since predynastic times, including Khufu, Khafre and Niuserre. Eduard Naville discovered blocks with Khufu's Serekh banner and Khafre's cartouche in the ruins of the temple of Bubastis (Naville, 1891: p. 5). In other words, Isis may have been a local deity known to Egyptian kings for centuries prior to the Old Kingdom.

Therefore, the occurrence of Isis on the Inventory Stele, as is the case for Osiris, is far from anachronistic to the Old Kingdom. Either she is a placeholder for Satet, which amounts to a one-symbol alteration on the stele, or she was a well-known provincial deity in Lower Egypt long before Khufu. The third possibility is that Satet and Isis were conflated when Khufu became king. Given the above evidence, the allegation that Isis was inserted into a fictitious story is the least likely possibility to which skeptics of the Inventory Stele are nevertheless clinging.

The name Hurwn for the Sphinx did not exist during the Old Kingdom. This paradox was pointed out by Selim Hassan (Hassan, 1953: p. 153). Hassan concluded that this name originally came from New Kingdom Canaanite settlers who recognized their hawk god "Hwron", a protector of kings and god of the dead (Hassan, 1953: p. 252), not only in the Egyptian Atum-Horemakhet-Horakhty (sun-lion-hawk/falcon) trinity, but possibly also the Egyptian god Sokar-Osiris. Consequently, they conflated their god "Hwron" with the Sphinx on votive steles they placed by the monument. The mention of "Hurna" and Hul" on these steles, several of which Hassan discovered in the 1930s, he surmised was the source material for the later Saitic scribe who referred to the Great Sphinx as "Hurwn" on the Inventory Stele. This, to him, was another strike against the stele's implied textual age and put the Khufu story into doubt. Hassan based his argument on interpreting Gardiner E23 phonetically as either " $r$ " or " 1 " instead of as a silent determinative. Presumably then, Gardiner V28-G43-E23-N35 on the Inventory Stele should be read as either "Hulen/Hulun" or "Huren/Hurwn", according to Hassan's reading of the spelling. But even the spelling itself varied among the various steles Hassan excavated and there seemed to have been no standard form, unlike is the case for Horemakhet and Horakhty. Horakhty, as does Atum, appears in the Old Kingdom's Pyramid Texts (e.g., Recitation 173/PT 263, Unis). Because of the intimate association between these two names and Horemakhet, as evident from early New Kingdom steles, the contention of an 
anachronism is harder to support with respect to mentions of these other two names for the Great Sphinx, Horemakhet and Horakhty, on the Inventory Stele.

Selim Hassan's case for the foreign origin of the name "Hurwn" is compelling, and we are inclined to agree with Hassan that this name is unlikely to have been copied from an Old Kingdom source. Rather, we think that Hurwn may have been another temple scribe edit to make the text relevant to the Late Period. However, we disagree with the conclusion that this anachronism invalidates the rest of the Khufu story, because, as in the case of the name Isis which may have been grafted onto the already well-established deity Satet in the Old Kingdom, we found evidence that the name Hurwn was likewise meaningfully grafted over an established attribute of the Great Sphinx during the same era. We do not believe that the mention of Hurwn or Hul on New Kingdom and Late Period texts is proof of an imported foreign myth superimposed over the myth of the Great Sphinx. Rather, we believe that a preexisting myth associated with the Great Sphinx was simply rebranded in the New Kingdom which makes this substitution likewise harmless. What matters to the truthfulness of the events described in the Khufu story on the Inventory Stele is that the attributes of the gods mentioned are not anachronistic even if their names are. We now proceed to show evidence that the attributes of the Great Sphinx as shown in the New Kingdom can be traced to the Old Kingdom, specifically, to the Pyramid Texts.

Ironically, the first clue to this connection was pointed out by Hassan himself (Hassan, 1953: p. 228): The Egyptian god "Hw" or " $\mathrm{Hu}$ " is shown on New Kingdom tomb paintings as a passenger of the night boat standing on the stern behind the soul of the dead king together with a group of other Ka spirits (Figure 18). $\mathrm{Hu}$ is attested as far back as the Pyramid Texts where there are two possible allusions (Wilkinson, 2003: p. 111; PT 251 and PT 697). Together with "Sja" he formed the Memphite Dyad, personified Annunciation and Perception, as part of Ptah, who himself is part of the creator (i.e. Atum) as documented in an early Middle Kingdom Coffin Text (Allen, 2005: p.196):

I am Annunciation, who is at his mouth, and Perception, who is in his belly.

Perhaps Sja and $\mathrm{Hu}$ originally were the words heard from the sounds made when breathing in and out; the very essence of being alive. Was $\mathrm{Hu}$ associated with or identical to the Great Sphinx? As the guardian of the Giza necropolis, the monument appears to also have been the personified underworld called Aker through which the solar night barque with $\mathrm{Hu}$ was believed to float (Hassan, 1953: p.228). Aker was shown as a double lion facing opposite directions and is mentioned in the Pyramid Texts (Allen, 2005: p. 293; Allen, 2013, Vol. II, PT 39). The first spell of the Coffin Texts begins with (Faulkner, 1973: p. 1):

Here begins the book of vindicating a man in the realm of the dead. Ho N! You are the Lion, you are the Double Lion, you are Horus, Protector of his father.

Besides Aker, the double lion was also called "Ruti" who is identified with the 


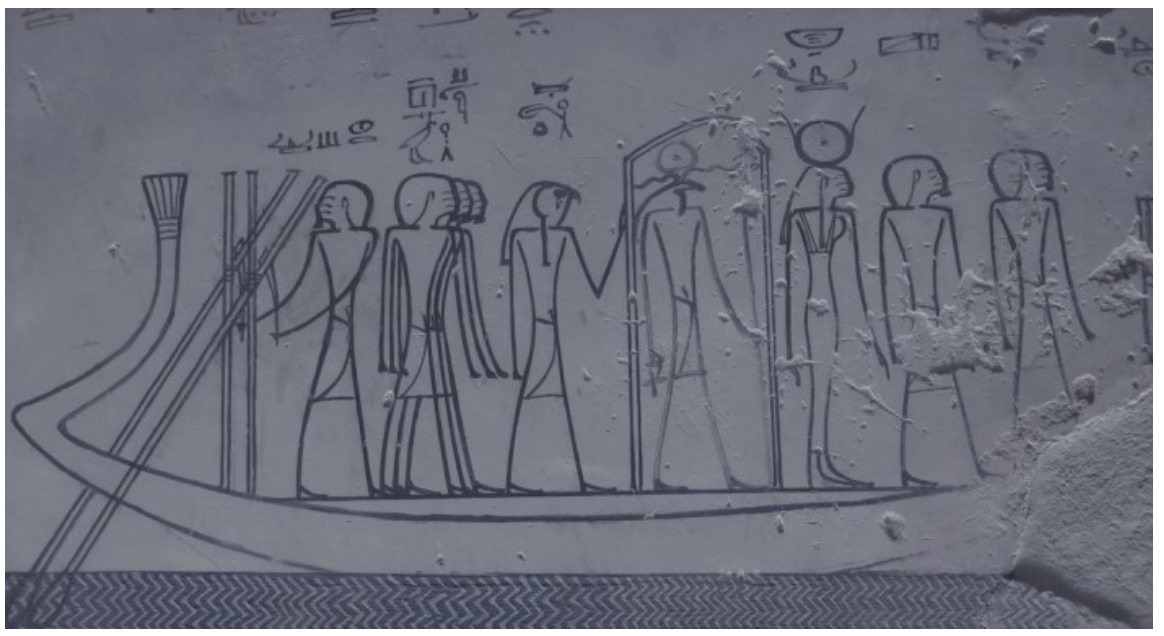

Figure 18. The solar night boat from the tomb of Thutmose IV. Under the pavilion is shown the ram-headed aspect of Atum. In front are Isis and Sja the god of perception who formed a divine dyad with "Hu". Immediately behind is the hawk-god guardian of the sun, probably Sokar ("Henu" is the name of his barque). Behind the hawk god is a group of figures, the first of which is "Hu" and the others are the "Ka of Shu" and "Nhs", i.e. night watcher. Photo courtesy of Manu Seyfzadeh, Feb. 2017.

Great Sphinx and closely associated with Atum (Hassan, 1953: p. 222). However, no clear identification between $\mathrm{Hu}$ and the Great Sphinx via this double lion aspect emerges from these texts and depictions, which may explain why no connection was later pursued. A closer association appears in the older Pyramid Texts of Teti. After the king's spirit crosses a celestial water-way to join Horakhty, he is on an 8-day wait to resurrect with the sun as a Horus. This transformation appears to involve the calling out of his name to the sun by the four pillars of heaven. With this context in mind, we read the following passage (Allen, 2005; Teti Recitation 187, page 79):

Teti will call to them and those four gods who stand at the sky's electrum staves will fetch themselves to him, that they might tell the name of Teti to the Sun and bear his name to Horus of the Akhet, (saying): "He has returned to you. He has come to you that he might loosen ties and release fetters."

In this passage, Allen translated the verb "wts.sn" as "they bear" as in "they might tell .... and bear his name to Horus of the Akhet". Other possible meanings are "lift-up", "raise", and "announce" (Vygus, 2015: p. 741). We think the best fit is "that they might tell the name of Teti to the Sun and announce his name to Horus of the Akhet ...”. In other words, the four cardinal pillars of the sky use the power of Heka to lift Teti's Akh-spirit up to the sky so that he becomes one with Horakhty by proclamation or annunciation.

Here we see a clear relationship between the four pillars holding up the realm of Re and Horakhty through the annunciating power of "Hu". Taken together, personified "Annunciation" was part of the king's entourage on his journey 
through the underworld over the body of conjoint twin lions called Aker or Ruti and it is through "Hu" that the king becomes Horakhty, the celestial Sphinx. The deeper meaning behind this role of the Sphinx associated with Heka is the concept of creation through recitation and its capture as written text, literally creating by naming things thought of to become words free, unleashed, unfettered and alive; a distinctly Memphite view of creation personified by Ptah (Wilkinson, 2003: p.124), later restaged in the Heliopolitean version with Re, as the "lord of the property of the place of the four papyrus-columns" (Allen, 2005: p. 33, recitation 150) and Horemakhet, Re's earthly emissary, who frees the king's spirit through Hu to become Horakhty. The same concept of creation through annunciation underlies the "mes" (birth; depicted with Gardiner F31) of symbols on $1^{\text {st }}$ Dynasty ivory oil tags and entrees on the Palermo Stone (Helck, 1987: p. 70). This metaphysical attribute of creation through "wording" imbued in Horakhty in association with the Great Sphinx likely has its primordial roots in Mehit, the lioness associated with writing and protecting the scribes' tent, from Egypt's early beginnings under Narmer, if not before. Is it therefore possible that the Inventory Stele could have referred to Hu and not Hurwn?

Even though we think this is not likely given Hassan's plausible link between New Kingdom votive steles and the Inventory Stele and the fact that despite strong associations we cannot unequivocally identify $\mathrm{Hu}$ with the Great Sphinx, we cannot rule it out completely and therefore mention it in passing at least. There are two occurrences of Hurwn on the Inventory Stele: First in sector $\mathbf{R}$, line 1 "The House of Hurwn", and second in sector B, line 1, "The Temenos of Hurwn Hor-em-akhet" south of the House of Isis. We already showed several possible Egyptian derivations to explain the name Hurwn beside the Canaanite name Hwron. In addition, and contrary to Hassan's assertion (Hassan, 1953: p. 222), it is possible that the word "Hwrn" in the text of the Inventory Stele, spelled Gardiner V28-G43-E23-N35, may be two words and the lion symbol may be a determinative and not used phonetically here (Figure 19). In other words, $\mathbf{R}$, line 1, could be read as V28-G43-E23 "Hw" (i.e. Annunciation) and N35 "n" as the nisbe "nj" ( $\mathrm{j}$ is dropped) "belonging". This would then translate as "... the House of $\mathrm{Hu}$ which belongs by Mehit" ... etc. Likewise, in B, line 1, Zivie-Coche's phrase "The temenos of the Haurun-Harmarkhis is south of the temple domain of Isis" could instead be read "The temenos of "Hw" (i.e. "Announcement") of Horemakhet is south of the House of Isis" where N35 is the second "of" in that phrase. However, we do not think this is the most likely translation because even though the latter appears plausible, the former does not due to the awkward appearing "nj-hr" construction before Mehit.

A second alternative interpretation of V28-G43 E23-N35 as two separate words with all four symbols pronounced is "Hw $\mathrm{Rn}$ ". "Hu Rn" could translate "he who announces the name", i.e. an epithet to refer to Hu. Nevertheless, based on our evidence so far, we cannot clearly identify the Great Sphinx with the god $\mathrm{Hu}$ regardless of which way the name spelled Hurwn was meant to be 


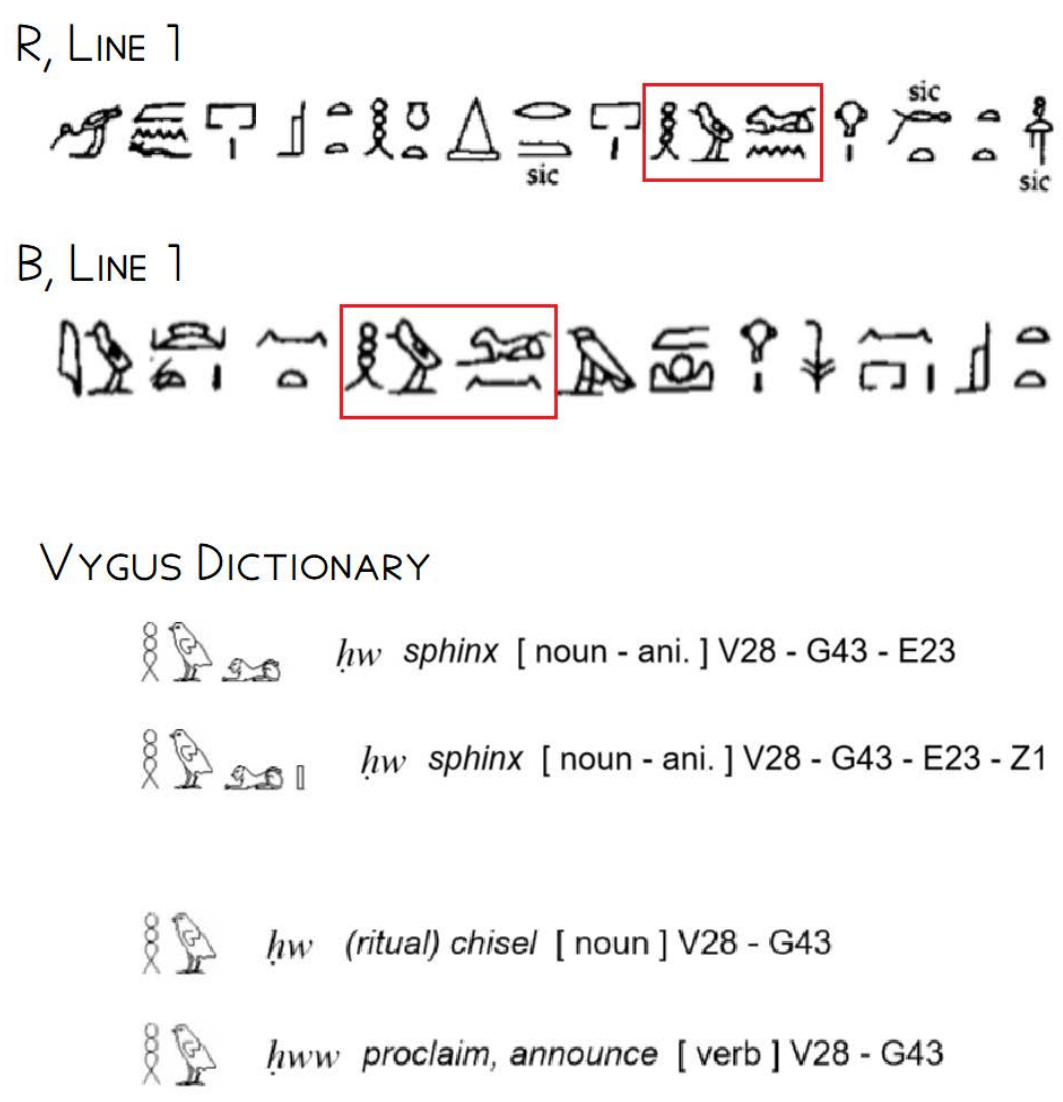

Figure 19. The two previously translated occurrences of the word "Hurwn/Haurun" in the Inventory Stele text, the first on line 1 in sector $\mathbf{R}$ and the second on line 1 in sector $\mathbf{B}$. Below are the relevant lexical entrees (Vygus, 2015: pp. 2215-2216). In the word "hw" when denoting Sphinx, the lion symbol E23 is silent and acts as a determinative, not as a spoken letter. Without the determinative, the word associates with the meaning of decree, i.e. a pronouncement made through a carved inscription.

pronounced and so we believe that Selim Hassan's explanation, while by no means the only one, is still the most plausible, namely that the names Hurwn and Hul were given to the Great Sphinx in the New Kingdom and that is why the name Hurwn was used in the text of the Inventory Stele. However, our evidence contradicts the idea that the mythology attached to that name was foreign to the Great Sphinx.

On the stele's apparition window, in the bottommost fourth register, the name "Hor-em-akhet" is inscribed above the back of the Great Sphinx, and, while there is no mention there of Hurwn (Figure 20), there is a remnant of the word for "statue" ("shsp"; not seen in Figure 20). There are several older New Kingdom steles however on which the Sphinx is called either Hwrna (e.g. Hassan 1953: p. 255) or Hul (e.g. Hassan, 1953: p. 261) and which show a large fan above the back of the monument (Figure 21 and Figure 22). The word for the fan symbol, Gardiner S36, is "Shuyt" which describes an attribute of the god of invisibility and air Shu, who together with his lioness sister and wife Tefnut formed the leonine "Adam and Eve", so to speak, of the Heliopolitean theology. Together 


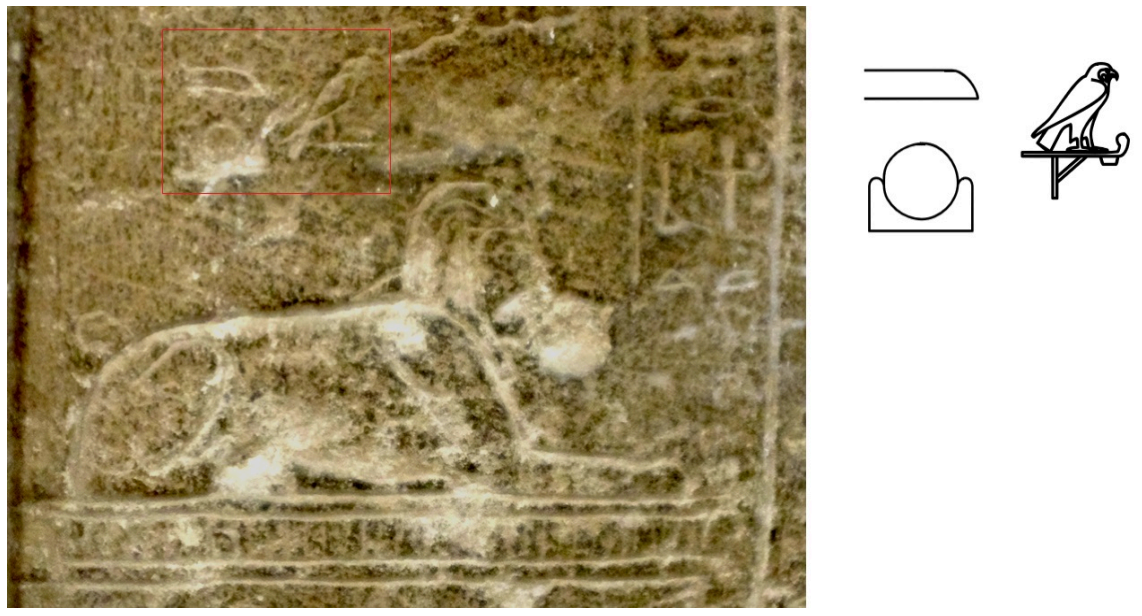

Figure 20. Lowest, fourth, register of the Inventory Stele's apparition window showing the Sphinx statue and the name "Hor-em-akhet" above framed in red, more clearly illustrated on the right. Photo courtesy of Robert Schoch, March 2017; modified.

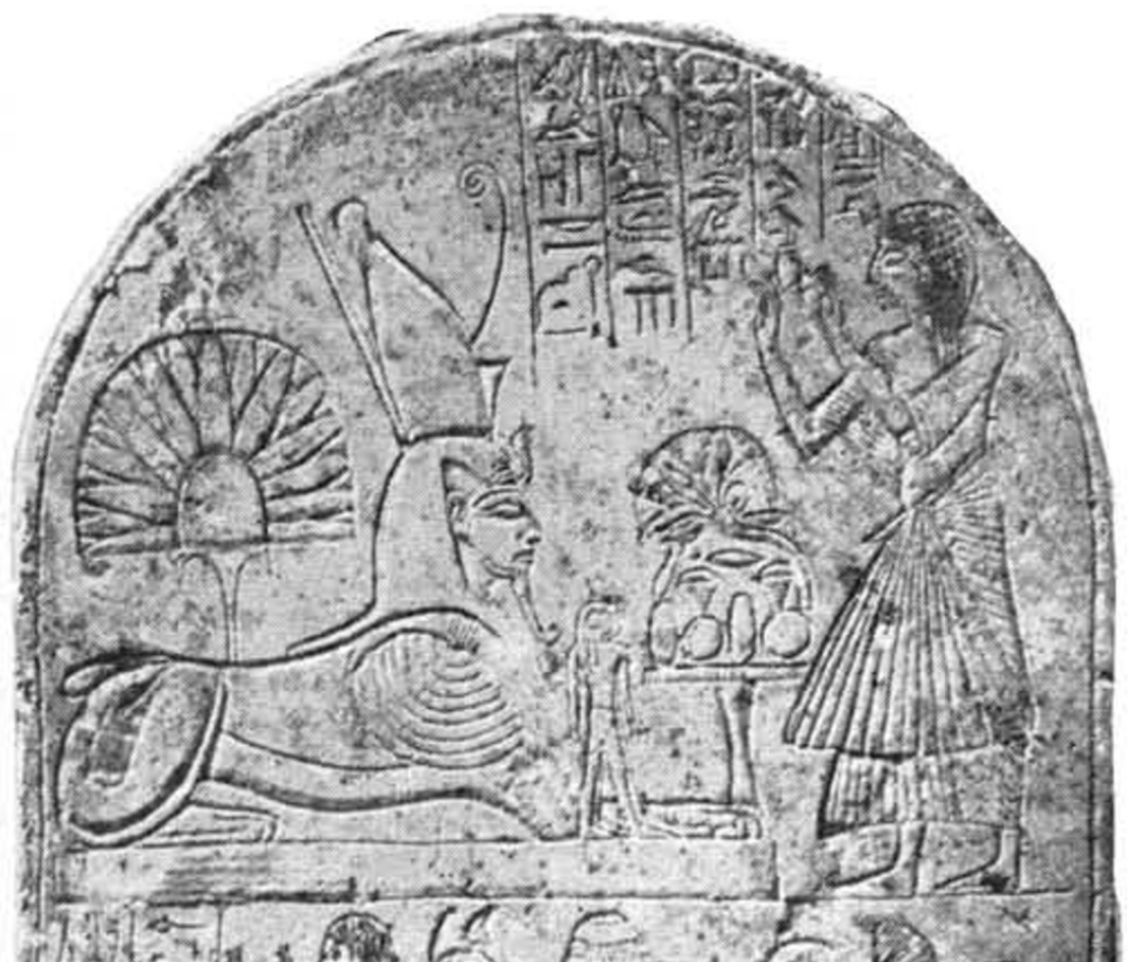

Figure 21. Upper part of stele No. 34 from Hassan (1953: p. 261). A large fan can be seen spreading across the back of the Great Sphinx, which in this example is called "Hul" according to Hassan's interpretation (see leftmost vertical register, first three symbols). Accordingly, the couchant lion hieroglyph is pronounced as "l".

with their offspring (Geb and Nut), their grandchildren (Osiris, Isis, Seth, Nephthys), and their great grandson (Horus), these nine gods and goddesses completed the Ennead family of original deities. Further clarification is provided by the New Kingdom stele of Paraemheb found near the Sphinx temple of Amenhotep II on whose verso a line of inscription reads (Hassan, 1953: p. 275): 


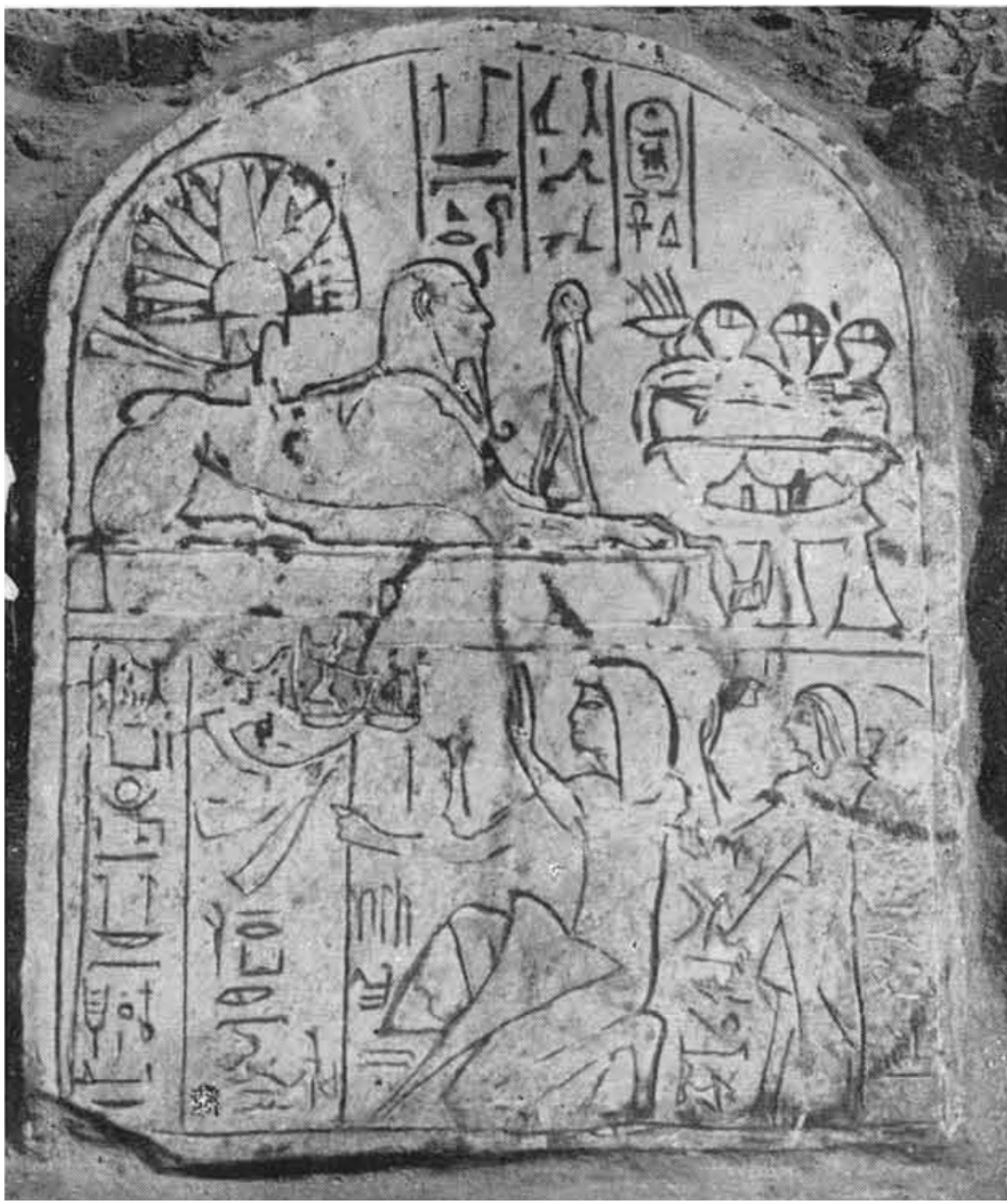

Figure 22. Stele No. 7 from Hassan (1953), Plate LXVII. In this example, the name of the Sphinx is in the middle vertical register on top and " $\mathrm{Hu}$ " is clearly demarcated with a vertical stroke while the lion and hawk symbols appear to be determinatives denoting the dual nature as both a lion and a hawk or falcon. Here again, a large fan can be seen hovering over the Sphinx's back.

Thou hast built for thee a castle in the Holy Desert, with hidden name (Shtyt), and thou risest in the sky opposite to them after thy manner of every morning, for ever".

Combining this description of a "castle of shadows" with the imagery of the fan symbol, the Sphinx was likely thought of as the guardian of the dead in the New Kingdom, as Hassan also posited. Yet more specifically, we propose the Great Sphinx was then thought of as the guardian of the realm of a specific aspect of the dead, their invisible shadows, which was believed to lie beneath the Giza necropolis. An allusion to Shu can also be seen in the earlier First Intermediate Period when the Sphinx was depicted wearing a feather on its head (Hassan, 1953: p. 231). We wondered if this association between the Great Sphinx 
and Shu on the one hand and the shadowy netherworld of the duat was again based on a much more ancient myth. Shu was the Lower Egyptian version of the Upper Egyptian god "Anhwr" (and Shu's consort Tefnut was the equivalent of Anhwr's consort Mehit). We noted the similarity between the names "Hwrna" and "Anhwr" and investigated if there was an Egyptian myth dating to the Old Kingdom with respect to this association. In fact, we discovered that this association is much older even and has its origins in the predynastic phase of Egypt.

We now proceed to examine the quintessential segment of the Pyramid Texts where the ritualized capturing of shadows through Heka was part of the creation of a mummified statue-like vessel from the dead king which was the Old Kingdom's stylized version of a much more ancient prehistoric tribal shaman rite: The concrete making of a statuette to commemorate a deceased. For this, we turn to the "Mouth-Opening Ritual" within the Offering Ritual (Allen, 2005: p. 20, recitations 25-31; PT 37-43).

In Figure 23, we show the hieroglyphic Pyramid Text 37-43 from the pyramid of Unis and the transliteration which allows one to see phonetic matches with other words which may be invoked with this text. We summarize the translation, which is not essential for our phonetic analysis, only to show that its meaning has little to do with the meaning of the activated words: Unis' mummy's mouth is fixated (PT37), opened using the Pesesh-kef knife and meteoric iron pieces were perhaps used to keep the mouth open (PT38). The lost "Horus Eye" is placed into the mouth in the form of Natron pellets from Upper and Lower Egypt (PT39). A mineral is given to Unis' mummy (PT 40). The mummy is given milk from the breast of Horus (PT 41). The mummy is given breast milk from his sister Isis (PT 42). Black and white "Horus Eyes" are placed on the face to brighten it (PT 43).

This text has already been analyzed for phonetic activators related to the statuette making custom (Helck, 1987: pp. 29-30), but we would like to point out a few not so far recognized, which we think are very relevant and hardly coincidental. We list them exactly in the order as they appear during the recitation, which matters if the words so activated line up into the familiar sequence of statuette making. In PT 37, marked in lavender, is the phonetic activation of the Sem priest using the word for "I have fixed" "smn.n(j)". Also, in PT 37, marked in pink, is the phonetic activation of "statue" ("shesepu") using the word "pshs.t" (spread) which is an anagram of "shsp". In PT 39, marked in grey, is the phonetic activation of a god "isdn" using the word for "put" ("sdn.k"). Immediately afterwards, is the phonetic activation of the double lion Ruti (i.e. "RuRu") using the word for "Zeru", salt from Upper and Lower Egypt, spelled using the actual couchant lion symbol Gardiner E23 twice. In PT 40, marked in black, the word for "shadow", "shju", is activated using the word "shjku". In PT 41, marked in gold, the word for "face", "hr", is activated using the word "hrw". Just below also in PT 41, marked in blue, is the phonetic activation of "White Chapel" ("Itrt") using the word "Irtt" (Milk, which is white), also a partial anagram. 


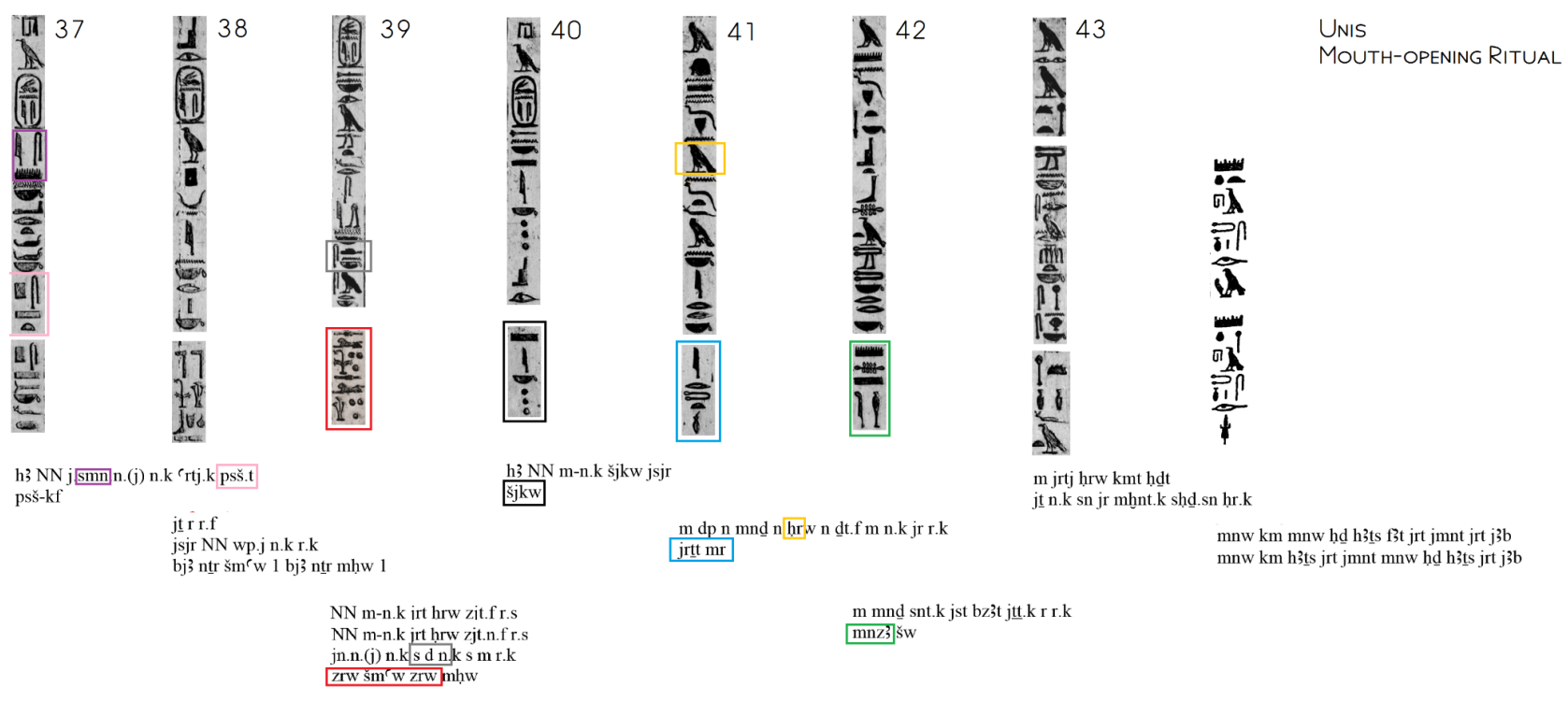

Figure 23. Hieroglyphic text and transliteration of PT 37-43, Unis (from Allen, 2013, Vol. I and II; modified). The color-marked rectangles show examples of phonetic activators of words related to the statuette making custom and are discussed in the text. The activated words and their Vygus (2015) dictionary page numbers (in parentheses) in order of their appearance are sm (p. 1782), shsp (p. 1615), isdn (p. 1134), zru (p. 395), shju (p. 1430), hr (p. 50), itrt (p. 1169), mnz3 (p. 2455), and shu (p. 1426). The semantic sequence therefore is Sem priest, statue, god, Ruti, shadow, face, white chapel, erection, and air.

In PT 42, marked in green, is the phonetic activation of the word "erection" (“mnz3") using the word for milk jug "mnz3". This latter Heka activation may discretely allude to the copulation between Isis and Osiris after she mummifies his dead body. "Shu" (air) is activated in PT 42 with the feather symbol, marked in green.

We thus obtain the following sequence of words insinuated: Sem priest, statue, god, Ruti, shadow, face, White Chapel, erection, and air. The presence of Shu strongly suggests that Ruti was originally imagined to be none other than Tefnut. An anagrammed phonetic hint just prior to Ruti in the same PT 39 is the word zjt.f (in later versions zjt.n.f) "went away". The invoked presence of this "first couple" of creation is highly significant in a ritual involving the resurrection of their grandson Osiris so that he can mate with their granddaughter Isis to make their great grandson Horus with whom the dead King's soul fuses to later become Horakhty. We conclude that the Mouth-Opening Ritual, at its deeper level, was the reenactment of the Heliopolitean myth of the transition from Zep Tepi (the first era of the dominion of the gods) to the dominion of man and his kings under the rule of Horus.

Yet, in nine hidden words, the Mouth-Opening Ritual communicated with the funerary congregation on an even deeper level connecting them to their ancestors' primordial past. While the lector priest recited the spells and performed the ritual on the dead king's mummy, he also brought to life a vision of a Sem carving a statue out of a piece of ivory using a swallow-tail knife, invoking Ruti to catch for him the shadow of the deceased, making a face from paint and gems and placing the so imbued and painted statue on a shrine in an act of physical 
and metaphysical creation. This duality is concealed in Isis herself: She is part of this creation both physically and symbolically in the shape of the swallow-tail knife, the pssh-kf, because in another version of the ritual she is animated using the word swallow, i.e. the bird, "mtn" (Helck, 1987: p. 26). The fundamental elements of the statuette making custom were thus indirectly brought to life, verbally animated that is, using phonetic allusions in the Pyramid Texts and this development in funerary liturgy correlated with the rise of Osiris to the top of the Egyptian pantheon and the practice of mummifying deceased royals to recreate them as statues to be revived with Heka.

Here we also have evidence the Heka priest class (for example Wepemnefret; see Seyfzadeh et al., 2017) during the Old Kingdom still viewed the Great Sphinx as a divine leonine spirit to be called upon to enter the shadowy realm it protected and secure an image of the dead king so that it would serve to reanimate his mummy and also as part of the reenactment of the theological foundation of man's dominion as viewed in Heliopolis. From here, the capture of images in the form of symbols to create an alphabet of outlined figures and objects and thus writing is a small leap of the imagination and may explain why the lioness Mehit became the patron goddess of this craft.

When all is added together, the Great Sphinx carried a level of prehistoric, early dynastic, and Old Kingdom cultural depth the name "Hurwn" could not possibly have erased assuming the name was in fact anachronistic. After all, the Egyptian, not foreign, word "Aha-Ru" means "Warrior Lion" (for an image of one see the Naqada II period Battlefield Palette which possibly also shows the spotted leopard garment of a Sem priest, circa 3300-3100 B.C.E.; British Museum \#20791) and " $\mathrm{Hu}-\mathrm{Ru}$ " resembles the call of a lioness (Lewa Wildlife Conservancy, 2015). Reasonable doubt therefore persists as to whether Hurwn is really an out-of-place and out-of-time name based on a story about the Old Kingdom's Great Sphinx considering that the ancient Egyptians provide plenty of etymological material to explain this name as we have now shown. The importance of the lion cult to kingship in the Old Kingdom is further demonstrated by the appearance of Sekhmet during the $5^{\text {th }}$ Dynasty who can be seen breast-feeding the young Niuserre-Ini (Figure 24), a vivid scene reminiscent of PT 41 and 42.

In summary, traces of the two most visible attributes of a lioness as a huntress and a protectress are evident in the Mehit and Sphinx cults of the first four Egyptian dynasties. As Mehit, the lioness protected written images kept inside of the writer's tent and, as we have previously argued, inside of a library vault under the Sphinx (Seyfzadeh et al., 2017). As Ruti, she hunted after shadowy images in the underworld to be verbally imbued into mummies with Heka as part of the resurrection protocol inside the pyramids.

Even though no direct evidence exists of a name for the Great Sphinx monument between the time of Khafre and the time of Thutmose I, her Old Kingdom attributes as shown can be plausibly connected to all her names found on the Inventory Stele. It is possible that New Kingdom Egyptians, like modern era 


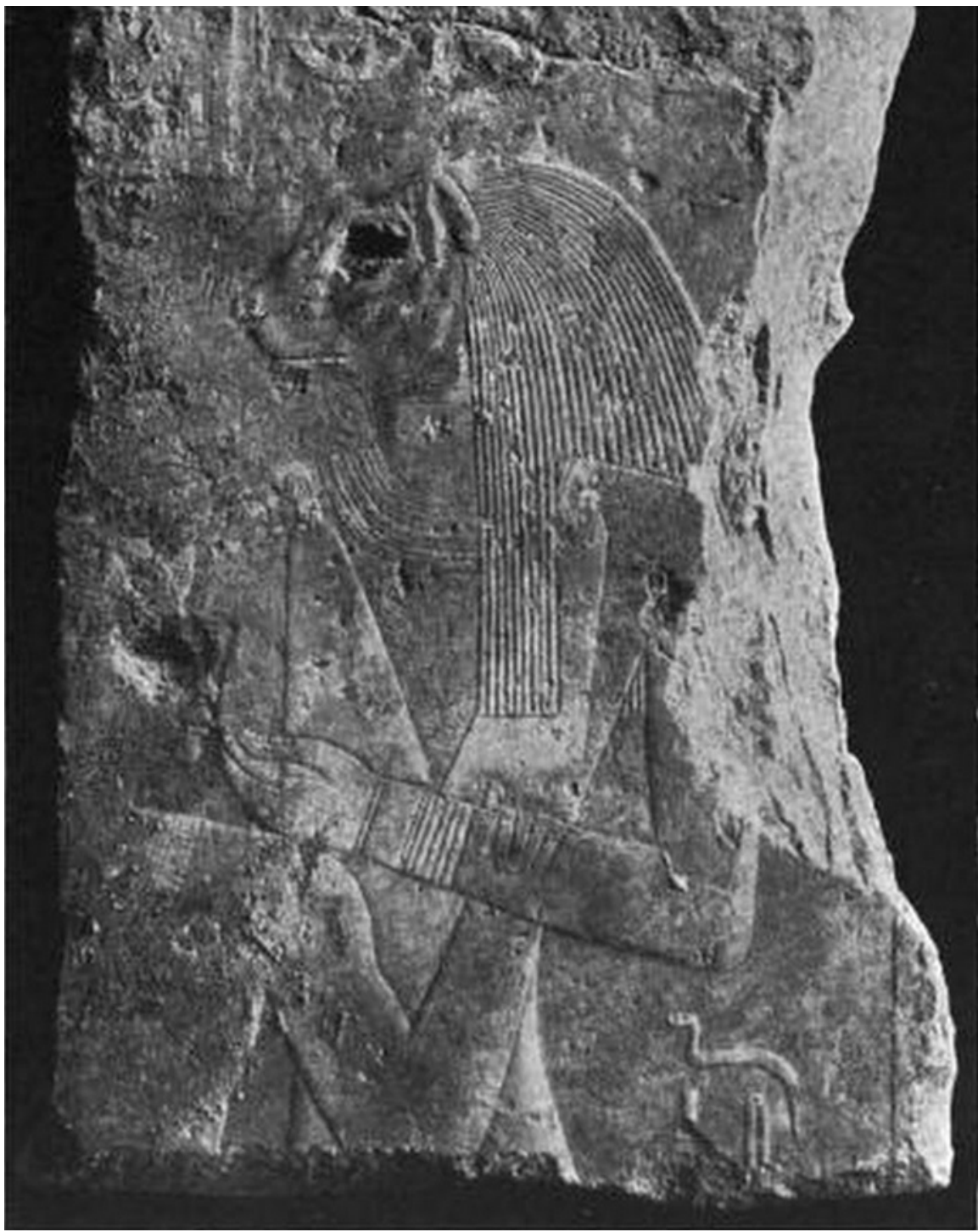

Figure 24. Relief from the mortuary temple of Niuserre at Abusir showing the lioness goddess Sekhmet breast-feeding the young Niuserre. From Das Grabdenkmal des Königs Ne-user-re by Ludwig Borchardt, 1907.

Egyptologists, had no records of a name for the Great Sphinx before their own time, but we do not think it is likely that they forgot what the Great Sphinx meant to Old Kingdom Egyptians since they seem to have preserved that heritage on steles and tomb paintings. Therefore, whatever names they chose for her, domestic or foreign, hardly implies a substantial anachronism in the context of an Old Kingdom text. In other words, the name Hurwn on the Inventory Stele is not an indication that a Canaanite name together with its associated myth was inserted into a story from the Old Kingdom, but, in the worst-case scenario, that a part of that story was given a Canaanite name which does not affect how believable the events of the story are.

The style of the Inventory Stele is of poor quality not commensurate with the age of its textual content. In addition to content and iconography conflicts, 
Christiane Zivie-Coche points to an overall poor quality of inscription and a lack of the usual mention by the scribe that it is a copy of an older record (e.g. the Shabaka Stone) as further proof that the Inventory Stele cannot be a copy of an Old Kingdom record, thereby dismissing Auguste Mariette's and Gaston Maspero's idea that it could indeed be a copy (Zivie-Coche, 1991: p. 220). However, the haphazard arrangement of the text on the stele and the fact that only a few of the gods in the inventory are mentioned indicate separate origins for the text and the actual inventory. While the entire stele in its lay-out may not be a copy of an older similar stele, explaining why the scribe did not identify it as such, the text could come from an older source. The quality of the inscription is only testimony to the skill and material used in copying such text, not the age of its content.

Based on our analysis, the style of the text also does not appear anachronistic. We examined the grammar of the stele's text and found it to be consistent with an older vintage than what was customary in the Late Period. For example, the use of the $s \underline{d}$ m.n.f verb form in a Late Egyptian text is unusual, as also noted by Zivie-Coche who however states that it is "usual in this type of inscriptions ..." (Zivie-Coche, 1991: p. 222). Instead, the past tense of transitive verbs was expressed using the $s \underline{d} m . f$ verb form. Yet, on the Inventory Stele, there are multiple instances of the $\underline{s} \underline{d} m . n . f$ (Figure 25). In the Old Kingdom, both forms were used, one to express the past and one to express completed action and so the persistent use of this verb form to the exclusion of the one normally expected in a Late Period text is very significant stylistic evidence that the text is much older than the stele on which it was inscribed. This is further corroborated by the archaic use of the triple plural and the genitival adjective "nt" (Figure 25). There is another example in L, line 3, where the demonstrative pronoun "nw" (Gardiner U19) in the phrase "nw neterw" ("these gods") is an archaic way to express the word "these" (Allen, 2014: p. 65). The more era-appropriate word would have been "nn" (Gardiner N35-N35) as in "nn neteru".

In general, the liberal use of prepositions in the entire text effectively rules out literary Late Egyptian as the language used to compose the original text. We cannot rule out that the scribe attempted to "age" the text by composing it in Old Kingdom style writing, "Traditional Egyptian", but the critics' claim that the writing style is anachronistic to the Old Kingdom is not in line with the evidence presented here. An example of a demonstrably "aged" inscription is the Adoption Stele, approximately from the same time as the Inventory Stele (Caminos, 1964). It is a royal proclamation of king Psammtik I to the high priestess of the temple of Amun, which explains the use of Traditional Egyptian since the actors are royal and of the highest priestly class. The stele's content dates the text. The Inventory Stele, on the other hand, we think is directed to a provincial audience and so we think the old style, in this case, dates the text and is not a stylistic feature used to enhance its royal appeal.

What proof exists that the story is true? Selim Hassan, himself a critic, was 


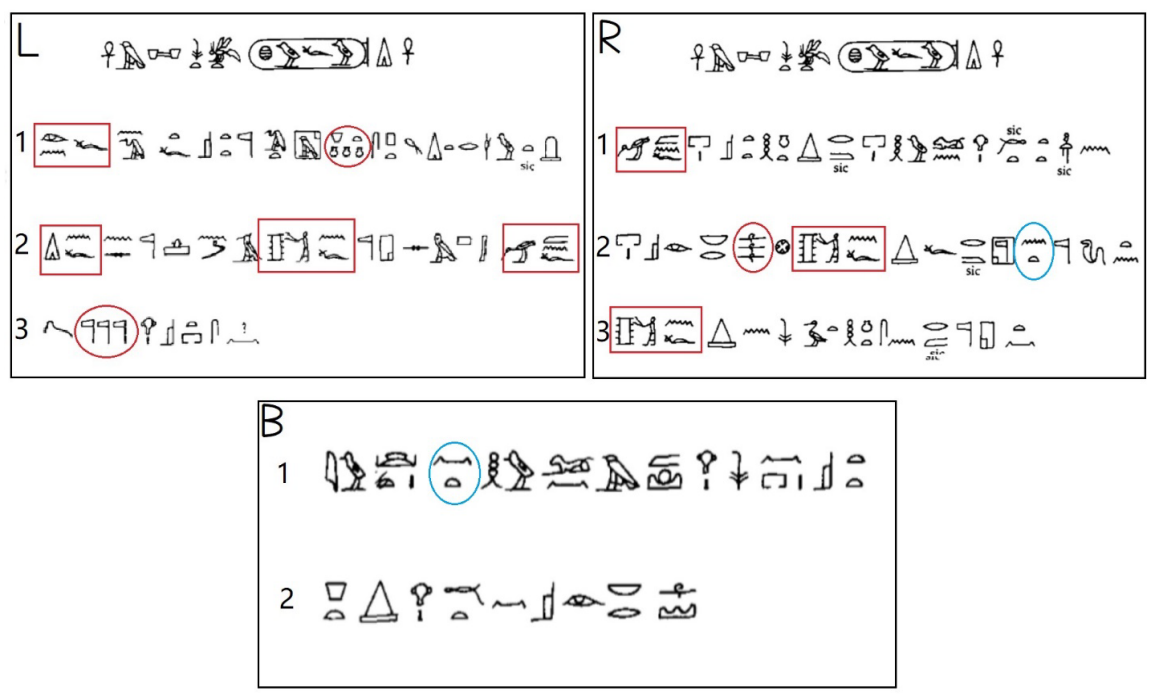

Figure 25. The $s \underline{d m}$.n.f verb form marked by red rectangles is used seven times in $\mathrm{L}$ and $\mathbf{R}$. This verb forms expressed a completed state in Old Egyptian and was abandoned in Late Egyptian. While the triple repeat to mark the plural for the word "gods" in L line 2 is not anachronistic in a Late Egyptian text, its use in the other two examples is (red circles). The use of the genitival adjective "nt" (blue circles) to express the indirect genitive is also unusual in a Late Period Text (Allen, 2014: pp. 46, 50-51, 267-268).

intrigued by one element of the story which he felt rang true: The lightning strike which hit a Sycamore tree (Hassan, 1953: p. 116), because he recognized this as a possible reference to a Sycamore tree south of the Sphinx. This tree may have had a network of roots thousands of years old allowing it, or more likely its descendants, to survive the extreme dryness during much of the time since the Old Kingdom (Figure 26). Several trees around the world are thousands of years old and so the idea that the Sycamore of Khufu's time, or its direct descendants, was still alive in Hassan's time is not far-fetched. Hassan also thought it plausible that a massive lightning strike may have broken off the back of the Sphinx's nemes headdress, which is what Khufu repaired as told by the stele (in the segment of $\mathbf{P}$ transcribed by Daressy only). We have, as did Christiane Zivie-Coche (Zivie-Coche, 1991: p. 238), some doubts about this part of the story, not because of the ancient author's veracity, but because of the modern-age transcription of the hieroglyphic text by Georges Émile Jules Daressy (Figure 4). However, it should be noted that when the transcription was made by Daressy, this portion of the Inventory Stele's inscription may have been less damaged and more complete than it was when Zivie-Coche and subsequent researchers (including ourselves) studied it; the Inventory Stele has apparently degraded since its initial discovery in the middle nineteenth century. Other elements of the story, for example the rebuilding of the House of Isis, also have a plausible basis.

In the valley temples of Sneferu's Bent Pyramid and Menkaure's pyramid G3, inscriptions and statues were found on which were recorded the establishment of estates in various nomes. The estates supplied not only the king's future funerary cult consumption, but also his anticipated 30-year jubilee, the "Heb-Sed" 


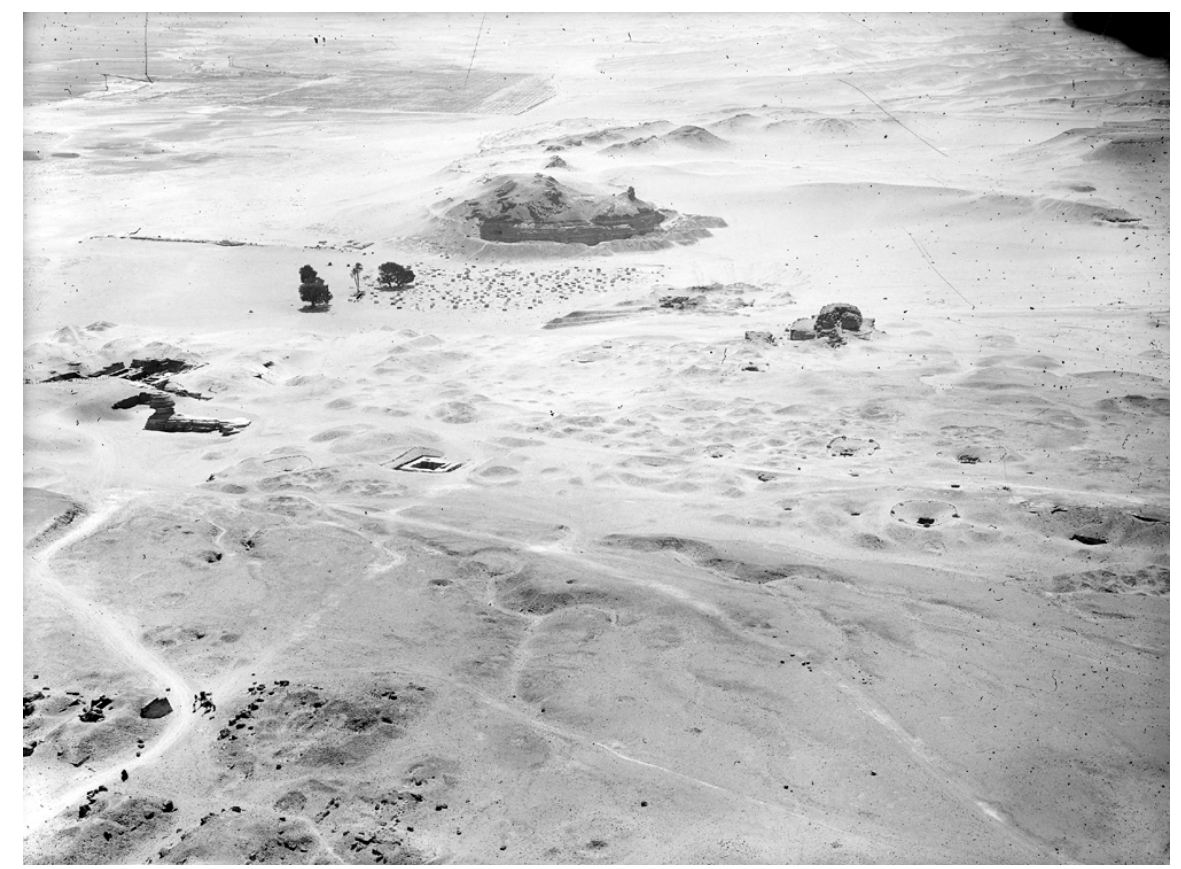

Figure 26. View of the Great Sphinx from the Khufu's Pyramid looking south, circa 1950. Isolated Sycamores grow near a cemetery in an otherwise desolate landscape. Near the trees is the "Wall of the Crow" and the then still undiscovered "workers' village" which presumably housed those who built the Giza pyramids. Photo courtesy of The Giza Project, Harvard University.

festival. At least in some cases, the type of economic output of these estates is known. Even though Khufu's valley temple has not been preserved, he is known to have established, or at least continued operating, estates on Elephantine Island and at Sheikh Said across the Nile from Hermopolis, the latter of which produced alabaster (Friedmann, 2015: p. 28 and references 50-53 in Friedmann). The latter estate had close ties to another believed to be in the Memphite nome which included Giza.

An estate, called a "hwt", comprised a temple and a farming village which supplied resources for the king. This was a form of provincial state extension using the cult of the goddess Hathor as the symbolic conduit. The temple was dedicated to her and it was she to whom villagers gave a portion of their produce for her to pass it onto the king. The pyramid valley temples can themselves be viewed as symbolic "hwt" estates, the final relay so to speak onto which all other estate supply lines converged. As we mentioned above, records of early dynastic shipments of oil suggest that a Buto language "Iset" estate also known as "Horus' Tree Garden" in Egyptian existed in the Delta which produced and delivered oil to the Thinite kings.

This then places a plausible context around the events described in the Inventory Stele, expressed in an analogous "telegram" style as early dynastic ivory tags and various royal annals (examples of which remain in the Palermo Stone and the London and Cairo fragments) which chronicled certain events as successive short statements to identify the year to which a certain lot of stored tomb goods 
dated. Accordingly, Khufu presumably discovered the site of an earlier abandoned estate at Giza used by predecessors; it is known that Giza was the site of early dynastic tombs. This estate may have served a predynastic or early dynastic funerary cult on the Giza Plateau. Therefore, Khufu rebuilt remnants of a preexisting estate to secure his own funerary provisions at likely the same site where the "Wall of the Crow" (Heit el-Ghurab) was later discovered by Mark Lehner (Lehner, 2002), immediately southeast of the Sycamore grove. He also rebuilt the estate's temple and in analogy to his predecessor Sneferu, this temple could have been a "mrt" shrine (or small temple), where the king symbolically marries the goddess which provides him with the necessities of life after death (Friedmann, 2015: p. 51). This "mrt" temple would have been in close association with a Valley Temple and a man-made harbor, as has been proposed in the case of Sneferu and Menkaure (Friedmann, 2015: p. 51), and could even be identical with it. In other words, if Khufu rebuilt a pre-existing Temple of Isis previously serving as part of a "hwt" estate, this temple would have been by the water at the foot of the Giza plateau and not on a hill immediately adjacent to his future pyramid, where the later Temple of Isis was erected. The Inventory Stele's description "by Mehit, west of the House of Osiris", therefore, makes perfect sense. Khufu's "mrt" temple and/or his "hwt" estate temple were inside a preexisting temple next to the Sphinx temple, i.e. the House of Isis according to the Inventory Stele. This is further proof that the Sphinx and the two adjacent temples attributed to Khafre existed even before Khufu.

The "Wall of the Crow" must have quickly grown out of this estate Khufu founded, because it would have made little sense for Khafre and Menkaure, whose names were found on seal impressions at the compound (Lehner, 2002: p. 34), to build a separate worker village elsewhere at Giza, and Khufu himself needed to supply thousands of workers to build his own pyramid (Figure 27). Alabaster found by Lehner at Heit el Ghurob (Lehner, 2002: p. 32) may well have come from Khufu's Sheikh Said "Hwt", since it did not naturally occur at Giza.

The estate-associated temple, we conclude based on the description in the text, was next to the Sphinx Temple in what is now known as Khafre's Valley Temple. This implies that the Valley Temple, after its rebuild by Khufu, served, at least initially, as his Giza estate's cult temple in analogy to Sneferu's Bent Pyramid Valley Temple at Dashur. The need to repair the Sphinx comes with the choice of his necropolis at Giza. Reviewing plans of its rebuilding is reminiscent of Eduard Naville's comment that Thutmose III reviewed old plans dated to Khufu to build the temple at Denderah (Naville, 1891: p. 5; referring to Mariette). Even the account of the eaten animals makes sense because the Giza valley was rich in game and promised to supply the estate with an endless supply of wild animal meat to supplement domesticated sources. And, as had been common practice under Sneferu, a pyramid would be erected by the estate, which would become "Khufu's Horizon", the Great Pyramid G1. Khufu's entire Giza project can thus be viewed as a master-planned, monumental version of a hwt 


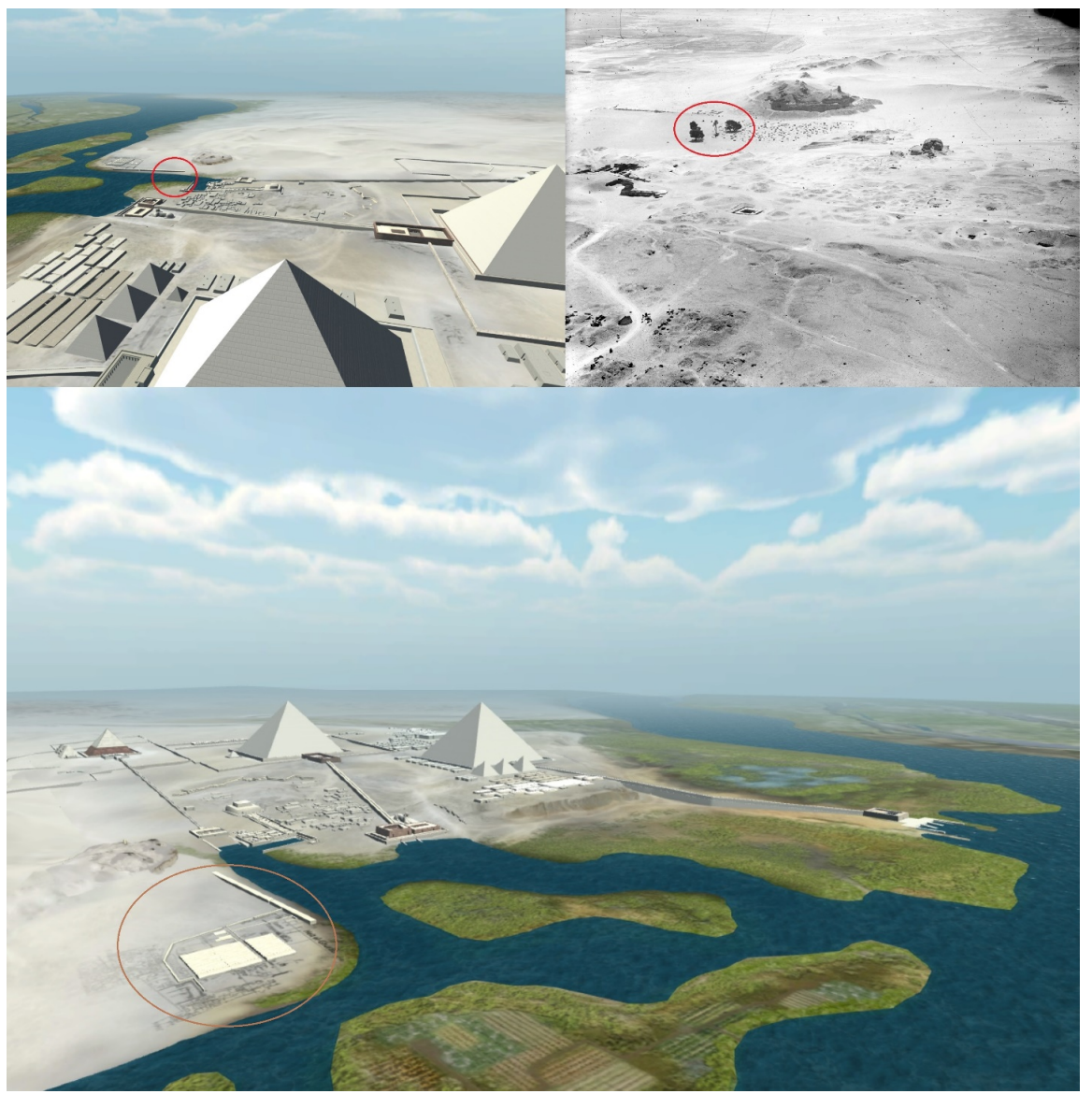

Figure 27. Top left: Location of the Sycamore grove (red circle) on a virtual reconstruction map of the Giza Plateau during the Old Kingdom looking south. Bottom: Looking northwest, the "Wall of the Crow" village (brown circle) can be seen to the southeast of the Sphinx complex and east of the Sycamore grove near Menkaure's Valley Temple in the graphic but had not yet been excavated in the photo (right top), which only shows the top of the wall itself. Photo and virtual reconstructions courtesy of Digital Giza and The Giza Project, Harvard University; modified.

estate dedicated to Satet/Isis and Khnum/Osiris (e.g. in part leaning on the theme of the hwt estate he built on Elephantine Island), which also plausibly explains two of the four visual targets in the night sky towards which the southern shafts of Khufu's pyramid point and the abiding of the next two pyramids' lay-out on the plateau by the astronomic alignments dictated by the three belt stars of Orion (Bauval \& Gilbert, 1994, Ch. 5 II).

When viewed against this historical background, suddenly nothing in the story on the Inventory Stele appears unrealistic; even the reference to Isis, which, as we considered above, the scribe may have edited in to adapt the story of a Satet estate cult to an Isis estate cult more relevant to his time. The fact that Khufu may have established an estate with a temple on the Nile banks of the Giza Plateau, as did his predecessor Sneferu and his grandson Menkaure under the auspices of "Hathor, Mistress of Sycamore", is not only plausible, it should be expected to be business as usual for Old Kingdom rulers. Even the conflation of 
Satet/Isis with this Hathor Sycamore cult is very apparent from the combined information in sectors $\mathbf{L}$ and $\mathbf{P}$ of the Inventory Stele. That too appears plausible now since it is precisely this Hathor cult which Menkaure still operated decades later to prepare for his "Heb-Sed" and into which the Isis cult merged after the religious shift instigated by his predecessors Khufu, Djedefre, and Khafre. With all that said, adherents of the Khafre-Sphinx Theory will insist that one part of the story remains in doubt: The notion that the Sphinx already existed when Khufu established his Giza estate. Having gone through this extensive analysis of the Inventory Stele, it almost seems strange for that part not to be also true, but one thing is clear: The categorical dismissal of the entire Inventory Stele to conveniently discard the possibility of an older Sphinx no longer works.

\section{Discussion}

Close examination of the text on the Inventory Stele shows that the widely cited criticisms of its historical authenticity are based on an inadequate evaluation of its content. Khufu's introduction at the outset and the style of language and grammar are consistent with the style and grammar of the Old Kingdom. At least some errors ascribed to the stele's creator are instead presumptions and errors on the part of the transcribers and translators, with significant consequences (e.g. Figure 4, Figure 9, Figure 19, Figure 25). The relief of Henutsen in G7130-7140 suggests she was indeed a princess. The location of the House of Isis as described is compatible with the time described and the text places it in a location separate from Temple of Isis. The events stated are consistent with what Egyptian kings commonly did, which is to establish estates and temples and dedicate them to patron goddesses like Hathor, and in this case possibly Satet, to assure a dedicated flow of goods from the provinces for their 30-year jubilee and funerary preparations. The temple Khufu rebuilt at Giza, possibly the proposed "mrt" shrine some kings built at the river bank entrances to their necropolises (Friedmann, 2015: pp. 50-51), may have become part of the "hwt" complex which grew into the "Wall of the Crow" on the southern tip of the valley's former river bay next to the Sycamore grove within the Sphinx's sacred precinct, the temenos. At the dawn of the pyramid age, building a pyramid next to important estates had already become established by Nebka or Huni and Sneferu.

Even the mention of a lightning strike which brought down a Sycamore tree is compatible with the unusual force and heat required to break off a part of the Sphinx as Selim Hassan considered. Evidence of such an unusually forceful rock-melting impact can be seen today in the form of vitrified rock around the Giza Plateau, a physical transformation which cannot be explained by the type of fires Old Kingdom Egyptians could have burnt (Schoch, 2016). The stele's account of Khufu's repairs of the Sphinx can be corroborated with Zahi Hawass's observation of the Old Kingdom hewn Tura stone casing of the body of the Great Sphinx (Hawass, 1993: p. 179):

At the very base of the Sphinx, where we have gained a good look at the 
mother rock, there are extremely large limestone blocks, similar to those from Turah in their quality, that cover the bedrock and form a casing or coating over the Sphinx. Since the hard Member I mother rock does not weather, its rough surface underneath these large blocks must have been left as we see it by the original Sphinx builders. It was also in this condition when the casing of the very large blocks just mentioned was added. The conclusion follows that these large blocks belong to an Old Kingdom casing that was done by Khafra's workmen in order to complete the modelling of the lion body, since the poor quality limestone of Member II, higher up and comprising most of the core body, would not suffice for fine modelling. The Sphinx architect tried to complete the mother rock sculpture by adding stones, exactly as the builders did with the pyramids, mastabas, and temples of this time.

We previously published evidence that the monument itself, before its remodeling and conversion into the Great Sphinx, was called Mehit, demonstrably a recumbent lioness (Seyfzadeh et al., 2017). This name is mentioned twice on the Inventory Stele, although not recognized by previous translators. Since there is no evidence that New Kingdom or Late Period Egyptians used this name for the Great Sphinx, its occurrence on the stele suggests that the original source text was composed at a time when Mehit was known, i.e. during the Old Kingdom.

The name Horemakhet, on the other hand, was known to New Kingdom and Late Period Egyptians, who used it to name the Great Sphinx. The occurrence of this name on the Inventory Stele is only a problem if no plausible connection can be made between it and Horakhty who is mentioned in the Pyramid Texts and with whom Horemakhet was very closely connected as early as the New Kingdom. Since the two names are closely related (Horus in the Horizon versus Horus of the [two] Horizon[s]) and the third member of the trinity Atum was also mentioned in the Pyramid Texts, we think the likelihood that Horemakhet was not known to Old Kingdom Egyptians is low. Regardless, on tomb inscriptions and in the Pyramid Texts, it would have made little sense to refer to the monument beyond its mythical counterpart in the sky, which may explain why there is no record of it.

The name Hurwn appears to be a foreign import as per Selim Hassan's extensive analysis of steles he discovered around the Sphinx. If the Khufu story on the Inventory Stele is true and was originally written during the Old Kingdom, the Saitic temple scribe who copied it must have inserted this name or, more likely, substituted it for an authentic, context-appropriate Old Kingdom name of a god, for example Mehit's consort Anheret (Anhwr), who was less relevant to the stele's Late Period's audience. We speculate that the original text mentioned the House and Place of Anhwr (in place of Hurwn and Horemakhet, respectively) by Mehit (instead of "North"), the lioness monument which only later became the Great Sphinx man-lion chimera. The myth behind Anhwr, i.e. he who returns the distant one (Mehit), well matches that of the Sem priest's prehistoric shaman 
function who in trance sent an animal spirit to catch the remnant image of the deceased from the netherworld of shadows. And so, it is possible that the Sphinx Temple, if it existed before Khafre as previously proposed (Schoch \& Bauval, 2017: pp. 188-191, 268), was a center of Heka magic during the Thinite period and early Old Kingdom, while the statue Mehit guarded the Giza counterpart of the Thinite royal tent of scribes and a library of scrolls (Seyfzadeh et al., 2017).

Changing a name does not mean the Khufu story was invented, however. Not only is the name plausibly associated with the early dynastic and Old Kingdom mythology of the Great Sphinx, but this mythology survived until the New Kingdom. Even if a foreign name was chosen for an Old Kingdom Sphinx, the Sphinx did not become a foreign Sphinx, which is the implication of the anachronism charge. On the contrary, the Great Sphinx, even as Hwrna or Hul, kept its association with the netherworld of shadows and language with which it was also associated in the Old Kingdom. The many names of the Great Sphinx appear bewildering and so we would like to propose a time line which places these names into their proper historic background.

In our model, predynastic Egyptians in Lower Egypt assigned a $\mathrm{Bu}-$ to-language name to a partially formed (i.e. frontal aspect only) prehistoric stone lioness at Giza they depicted as a couchant lioness with neck rings and a bent rod. This symbol was pronounced as Mehit in the language of Upper Egypt after unification by Narmer. Mehit became the patron goddess of the royal scribes and was also important to practitioners of Heka, the Sem priests, potentially as the chief animal spirit to be conjured in the process of inaugurating new symbols (the "mes" entrees on ivory tags). Once the monument's rump was completed and the head of the lioness was re-carved by either Khufu or Khafre, the monument proper became the Great Sphinx. This occurred during a religious shift from a world view colored by the Memphite and Hermopolitean theologies of Ptah and Thoth to that of Heliopolis centered around Re (Breasted, 1912; Hawass, 1996; Stadelmann, 1997) even though the astronomy behind the solar mythology may have been much older (Schoch \& Bauval, 2017: pp. 219-226; originally Mehit may well have been part of a primordial solar cult which was replaced or supplemented by a stellar cult, and only later reverted back to a solar cult). Consequently, the new mythology which took shape during the time of Khufu's heirs became enriched with solar metaphors and so the Great Sphinx became a physical manifestation of Re on the ground. Mehit had become the Horemakhet-Re-Horakhty trinity.

Once the Giza Pyramids were built and the new royal necropolis was established, the Great Sphinx also became associated with the underworld of Sokar and Osiris and assumed the names Ruti and Aker, while the solar cult became more focused on the evening sun Atum. All these elements of the lion cult built up over the preceding centuries were preserved in the Pyramid Texts. There are allusions to the statuette-making custom, allusions to verbal creation and verbal magic, allusions to the daily path of the sun, and allusions to a connection with 
the underworld.

This multi-layered mythology built around the Great Sphinx is the heritage which passed through the Middle Kingdom to the New Kingdom while the monument became covered with sand and was ignored as the capital of Egypt moved from Memphis to Thebes. When Amenhotep II and his son Thutmose IV decided to revive the Sphinx cult, all these themes had survived. While the multitude of names and depictions of the Great Sphinx which came afterwards seems bewildering, it is only a reflection of the many layers of preserved mythology still reverberating then. This multi-layered mythology is reflected in the Inventory Stele, where the Great Sphinx is called "statue", Horemakhet, Horakhty, and Hurwn all at once in a few lines of text. We think the value of the story told there should be appraised from within the context of the mythology which prevailed at the time, not the names used to refer to it.

The most controversial aspect of the Inventory Stele is the mention of Isis and Osiris. Our evidence shows that the worst-case scenario one can reasonably consider is that the scribe intentionally conflated Isis with the likely original Satet, who was indeed a mistress of a pyramid, namely one built on her island of Elephantine. If the scribe cheated with the name of Isis, the cheat was clumsy. S/he used a spelling not only uncommon to the Late Period, but also uncommon to all of Egypt's prior written history. Besides asking us to believe this "clumsy fraudster" image of a temple scribe, the "pious fraud" theory forces us to also to believe that s/he would choose Khufu over Khafre as the protagonist in an allegedly fictitious tale. Neither Khufu nor a Sphinx before Khafre helped sell the Temple of Isis to its patrons above and beyond what the antiquity of Khafre would have sold. A story featuring Khafre could have been backed up with his mention on the nearby Dream Stele, already placed 700 years prior. If we believe Herodotus and the evidence of a long-lasting Khafre cult at Giza, Khufu's reputation was inferior to that of his son. Egyptologists who do not want to believe the Inventory Stele want others to believe that it is among the possibly most poorly executed pieces of historical fraud in the history of Egypt, because they cannot accept what the story says.

Even Christiane Zivie-Coche did not subscribe to the "pious fraud" theory which claims that the stele was fraudulently aged. Instead, she concluded that the special reverence to Khufu (Cheops) was in line with a new sense of archaic pride emerging in the $26^{\text {th }}$ Dynasty when Psammtik I reunited a fragmented Egypt from prior Assyrian rule. The purpose of the anachronisms, in her opinion, was not to make the stele look older, but to honor the memory of an ancient ancestor and to impart a sense of nobility (Zivie-Coche, 1991: p. 222). In other words, the anachronisms may be limited to the agents mentioned in a text rather than the events attributed to them and there was no intent to deceive.

Critics may ask what distinguishes the Inventory Stele from other texts and icons known or suspected to be non-historical and fictitious, even if not fraudulently so? Zivie-Coche lists the following examples which may illustrate the dif- 
ference (Zivie-Coche, 1991: pp. 221-222): 1) The famous ivory statuette of Khufu discovered in Abydos which may date to the $26^{\text {th }}$ Dynasty and therefore may not be a true depiction of the king; 2 ) the $22^{\text {nd }}$ Dynasty Stele of Petubastis I from the Serapeum which mentions $3^{\text {rd }}$ Dynasty king Djoser; 3 ) the Saite or Persian era sarcophagus of Menkaure with inscriptions from the Pyramid Texts; 4) four columns in the small temple of $20^{\text {th }}$ Dynasty's pharaoh Ramses III's Medinet Habu which refer to $18^{\text {th }}$ Dynasty's pharaoh Thutmose III alive three centuries prior; 5) the Bentresh Stele from the Persian or Ptolemaic era, presumed to be a pure propaganda piece, which refers to $18^{\text {th }}$ Dynasty pharaoh Thutmose IV and $20^{\text {th }}$ Dynasty pharaoh Ramses II; and 6) the Ptolemaic era Famine Stele which refers to king Djoser and his vizier Imhotep. The Stele of Qahedjet could also be added to this list as a suspected feigned archaic depiction of Thutmose III made to look like Huni.

These examples fall into three categories: Either it is a material fake copy of an older object (statuette and sarcophagus), or a real story's impact is enhanced with fictitious characters (e.g. Famine Stele, Petubastis Stele, and Medinet Ha$\mathrm{bu}$ ), or an authentic character is inserted into a story whose events are embellished or made-up for propaganda (Bentresh Stele, Qahedjet Stele). In other words, the few examples of historical fraud from ancient Egypt show that the scribing perpetrators either cheated with the characters or with the story, but not both. The reason is obvious: In order to be believable, there had to be an element of truth emanating either from the agents or their actions. For example, Ramses II evidently fought with the Hittites, but the story told of a glorious devastating defeat of his enemies was probably an embellishment. That embellishment was believed because Ramses did in fact march to Kadesh and engaged in battle.

No such embellishments of events appear in the story of the Inventory Stele. They are, as we have shown, rather mundane and well documented in the Old Kingdom until one introduces the main character Khufu into the story. Only then arises suspicion of authenticity when the actual age of the text is considered. The descriptions and events on the Inventory Stele are specific to the Giza Plateau and include real details like the Sycamore tree on the southern edge and the lay-out of the precinct, houses, and temple, which is difficult to explain away as imagined by the scribe. What makes the Inventory Stele plausible is not the mention of Khufu but the mention of ordinary, rather mundane events and details similar to those chronicled on early dynastic ivory tags and the Royal Annals Stele. Khufu's mention on the Inventory Stele does not authenticate these events and details. However, since at least some of these events were probably not instigated by anyone other than Khufu, i.e. the building of his own pyramid, and since Khufu was clearly the worse choice in a hypothetical pious fraud scenario, they authenticate him as the true protagonist of the story and that includes his bearing witness to the Great Sphinx monument. The fact that Khufu may have known the Great Sphinx monument would have been a mundane piece of information in the $7^{\text {th }}$ century B.C.E. when the stele was likely made. It 
only assumes a controversial character because of the modern time dispute surrounding its origin.

By contrast, the mention of Djoser and Imhotep in the story on the Famine Stele for example does not necessarily and truly anchor the story to the time of these actors. It is possible that any seven-year famine in the long history of Egypt, not necessarily one which occurred during the $3^{\text {rd }}$ Dynasty, could have inspired the text and the main protagonists, Djoser and Imhotep, were simply inserted to enhance the story's impact, not its plausibility.

Even our worst-case "fraud" scenario, let alone that of the stele's traditional critics, diminishes in relevance, if one considers the circumstantial evidence that the origin of the name Isis had long-established roots at another estate of the Delta, possibly the oil-producing "Horus' Tree Garden" estate, and that her later celestial association, as well as that of her consort Osiris, feature prominently in the lay-out and design of the Giza Pyramids. In other words, there is a good chance the scribe of the Inventory Stele did not even edit in the name of Isis, because she was probably a known patron deity of a regional estate in the eastern Delta, perhaps around Baset (Tell Basta) or by today's Mansoura, with long-established trading routes and agricultural support of the royal house, when Khufu came to power and found parallels between her and his own patron god Khnum's consort Satet. Unfortunately, recovery of evidence from Egypt's Delta region has lagged other areas and much evidence may be lost due to millennia of alluvial flooding.

The mention of Osiris, his house that is, on the Inventory Stele is even less surprising considering that he may well be the most-mentioned god in the Pyramid Texts. In the Pyramid Texts of Unis, Osiris is mentioned more than ten times as often as Isis and three times more than the sun god Atum, the main star of the post-Khufu religious reform archeologically documented by Zahi Hawass (Hawass, 1996). Osiris' name on Ptahshesep's tomb, to whom first offerings were given even before Anubis, strongly suggests that this god was important before the $5^{\text {th }}$ Dynasty and his earlier recognition is also supported by the advent of mummification giving the dead a statue-like appearance thus preparing the king for a resurrection ritual similar to the more ancient statuette making ritual of prehistoric times.

Yet, Inventory Stele critics want to believe that his mention on the Inventory Stele proves an anachronism. First appearances of archeological records do not prove original appearances, they merely indicate what records have survived. They can only define the latest boundary of a time bracket during which an event occurred. The claim of an anachronism implies the notion that the earliest known records prove first instances, and this has been shown to be false many times before, when even earlier records are eventually found. Absence of earlier records does not prove that earlier events occurred, but absence of such proof does not mean they did not. In this case, there is a relatively short time interval between definitive proof and what is plausible: A time interval defined by less than the overlapping life-times of Khufu, Menkaure, and Ptahshesep. On this 
time interval was hung the notion of anachronism and fraud by those experts in the field who have summarily dismissed the content of the Inventory Stele.

In our best-case scenario, we place the original composer of the stele's text, at the latest, during the time of Niuserre, when Osiris and Isis first appear in writing, and, at the earliest, after Khafre, when the Great Sphinx myth of Re-Horakhty would have begun to take shape and replace whatever myth was associated with the prior monument, which we have shown to have been Mehit. Niuserre instigated repair work on Menkaure's Valley Temple, where the few statue triads of Menkaure, Hathor, and a local nome deity symbolically recall his major estates (Reisner, 1931: pp. 36-46). Perhaps it was Niuserre who revived a dormant Osiris and Isis cult evident at Giza when he revisited the site. Another link between Niuserre and the Giza kings is that both he and Khafre (and likely Khufu) were being supplied by the "hwt" estate in Baset (Friedmann, 2015: p. 35; Naville, 1891: p. 5). Niuserre's efforts to repair and reinstate his Giza ancestors' necropolis provides the necessary context in which the creation of such records would have been ordered in line with the creation of other steles like the Royal Annals of the Kings of the Old Kingdom. This theme of reinstatement is exactly what the story tells about what Khufu did. He, like Niuserre, found an abandoned estate, temple, and lioness monument at Giza and reinstated them. The parallels, if anything, are compelling and contemporary, not anachronistic.

Consequently, it is inconceivable that a scribe then alive would not have been also aware of Isis and Osiris and, at the same time, not still have had access to records, or even just credible hear-say, documenting what Khufu did in Giza. There are clues on the Inventory Stele that the story was originally written down from a verbal report, for example the use of the demonstrative pronoun "na", Gardiner N35-G1, ("this/that image of Hor-em-akhet") at the beginning of $\mathbf{P}$ is not an appropriate style of word use on a temple stele like this. The more appropriate choice would have been "nn". The more interesting interpretation yet, is that the target audience of the Inventory Stele's text was visitors from the provinces with whom the stele may have struck a more colloquial form of the language. This may explain the "poor" style of the text which critics have used to make their fraud case.

The main part of the Inventory Stele besides the text, its apparition window, shows a list of apparently contemporary temple statues of the Saite Period Temple of Isis erected away from where Khufu likely built his "hwt" estate temple, namely in a much more convenient location by the water, not on the hill on which he built G1 (the Great Pyramid). The purpose of the Inventory Stele, no doubt, was to showcase these statues and relay a story featuring Isis to dedicate the later temple, but the statues depicted in the stele's center are not at issue, only the text surrounding them. Its critics appear to have misread Gaston Maspero's published comments (see discussion below), or taken them out of context, in their effort to discredit the story and allege fraud. They have pointed to anachronisms which, in this case, would be words used to describe something 
during the Old Kingdom, which did not then exist, for example Isis. They have focused on the word "Isis" above all the other alleged anachronisms, which we have individually addressed in this paper. However, if there is one piece of evidence to exonerate the scribe and attest to the true antiquity of the text he/she inscribed, it would be the converse: It would be a word not known to have existed in the Late Period which the scribe nevertheless had to faithfully transcribe, for example the name Mehit. But is there another such word?

James Henry Breasted and Christiane Zivie-Coche struggled with their interpretation of the word "sepat" spelled Gardiner S29-Q3-X1-V12 as evidenced by their very different translations of this word (Figure 28). He translated "Mistress of the Western Mountains" and she wrote "Mistress of the Sky"; both, incidentally, attributes given to Satet in the Pyramid Texts of Pepi and in later inscriptions on her temple (see above), further underscoring our thesis that the original goddess in the story was Satet.

Nevertheless, a "sepat" is neither a mountain in the west nor the sky. A "sepat" was a nome. A nome was a city-state province in ancient Egypt ruled by a local governor called a nomarch and personified by a local god(dess) such as the one standing next to Menkaure or Hathor on his several triads. The names of these nomes and their numbers are best attested from the Middle Kingdom onwards inscribed on Senwosret I's White Chapel at Karnak; information about them from the Old Kingdom is incomplete and only the names of nomes in which kings established important estates are known. Only four of the later
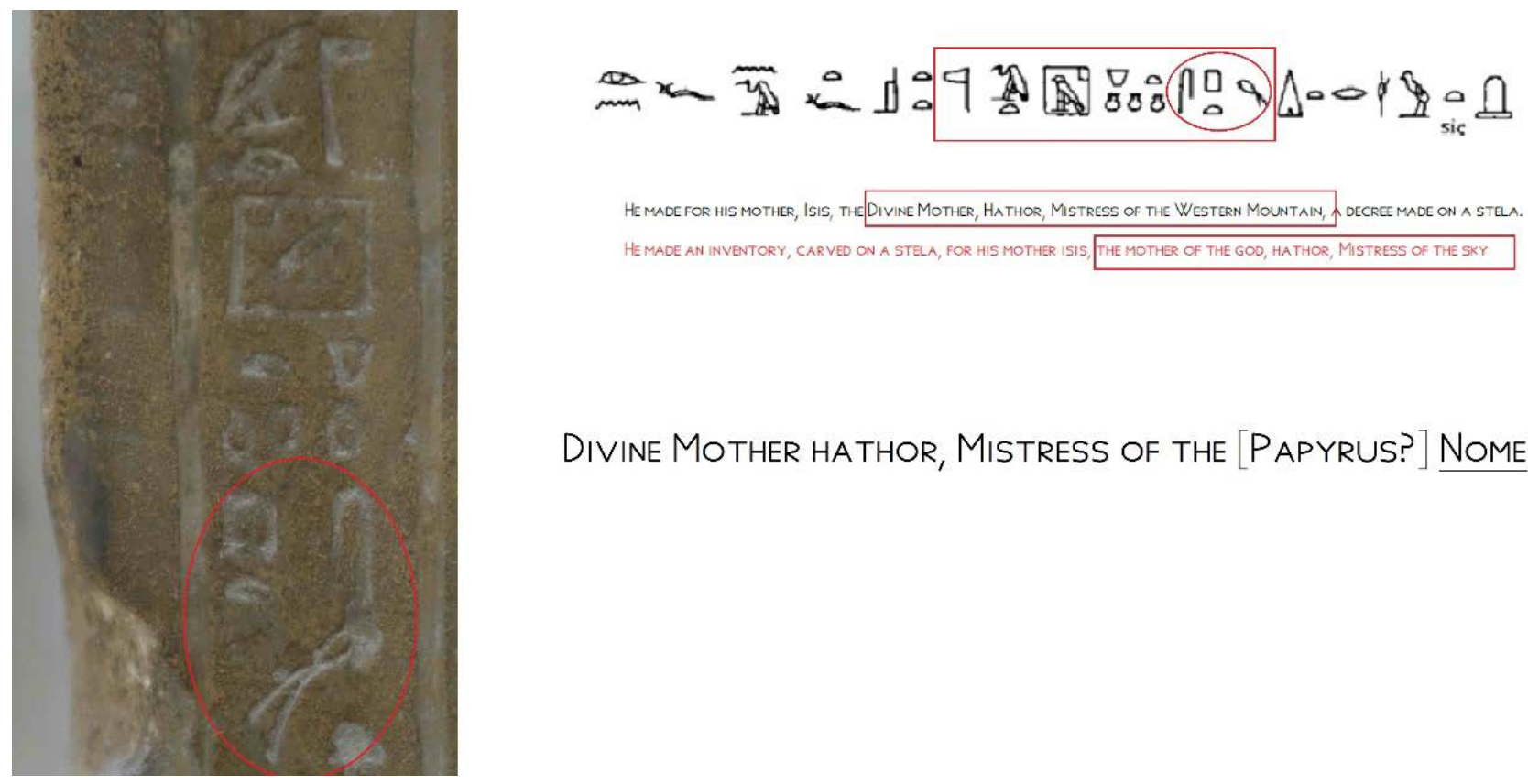

Divine Mother hathor, Mistress of the [PAPYRUS?] NOME

Figure 28. On the left is a photo of a segment of $\mathrm{L}$. On the top right is $\mathrm{L}$, line 1 with the relevant words marked by the red rectangle. Breasted and Zivie-Coche's translations are shown immediately below in black and red, respectively. On the bottom right is the correct translation. The word encircled should read "Sepat" (i.e. nome) but was translated as Western Mountain by Breasted and Sky by Zivie-Coche. A nome was a city-state district in ancient Egypt. Photo courtesy of Robert Schoch, March 2017; modified. 
Lower Egyptian nomes are known to have existed by the time of Djoser: 2, 3, 6, 16 (Willems, 2014: p. 11). Remarkably, there is no known nome with the name "Papyrus" scroll indicated by the determinative sign V12 and the nome symbol Gardiner N24, long in use in the Late Period, is missing. On the Adoption Stele, for example, there are several explicit references to nomes where the word is spelled Gardiner N24-X1 (i.e. Sepat). Meanwhile, there is no instance there of the spelling S29-Q3-X1 for a "Sepat" let alone the mention of a nome identified with a papyrus scroll symbol (Caminos, 1964). Where could this nome, or perhaps estate within a nome, have been located during the Old Kingdom?

The twin city "Per-Wadjet" (Buto; the cities of "Pe" and "Dep") in the Delta was home to the Cobra goddess Wadjet whose shrine was shared between them and who symbolized all of Lower Egypt as part of the second oldest royal title, the "Two Ladies" Nekhbet and Wadjet. Later, in the Middle Kingdom on the "White Chapel", two nomes were recorded sharing Per-Wadjet: The fifth and sixth nome of Lower Egypt. The name "Wadjet" means "he/she who is the color of Papyrus". Unlike was the case in Upper Egypt, nomes in Lower Egypt tended to change because the varying inundations each year redrew the map of the Delta periodically.

Since we have no record of a "Papyrus Nome" in the Old Kingdom or later (see Nome List, 2018), a scribe alive after the Middle Kingdom, let alone the Late Period, would not have recognized this word. It is possible that this was the name of an older nome or perhaps a larger "hwt" estate within a nome during the Old Kingdom, whose patroness was Hathor, the Mistress of the Sycamore, with whom Wadjet became conflated. Evidence of a similarly named farm complex or sub-district called "Sepa" located within the Delta nome of Neith can be seen in the inscriptions on the tomb walls of the late $3^{\text {rd }}$ and early $4^{\text {th }}$ Dynasty official Metjen's mastaba L6 at Saqqara (Hratch Papazian, personal communication). Interestingly, the papyrus sheet symbol V12 could also designate the "fnkhu" people (a "fenkh" was a carpenter), perhaps Syrians from Ebla or Phoenicians from Byblos with whom Egypt traded long before Khufu and who may have established an immigrant trading post like Buto in the Delta, whose early provincial designation during the Old Kingdom was "Carpenter Nome" or "Carpenter Estate".

The presence of the cryptic word "Papyrus (or Carpenter) Nome" on the Inventory Stele, likely an unusual word for a Saite era scribe, is proof that $s /$ he was not inventing the text $s /$ he inscribed. It proves that $s /$ he was copying an older text which contained a word foreign to her/his time, and yet s/he felt compelled to keep it as is. The fact that the colloquial tone of the language pointed out above was also kept in place further underscores this impression. The Saite era scribe copied what $\mathrm{s} /$ he saw written down and made no effort to adapt the text to make it contemporary. This directly contradicts the claim of those who view the stele as a pious fraud, because it mentions Isis and Osiris or because its disagrees with the Khafre-Sphinx Theory. Gaston Maspero wrote (quoted in Hassan, 1953: p. 117): 
... If it is a copy of a decayed monument, it probably preserves the arrangement of the original.

Even though he thought the Inventory Stele is not an original made in the time of Khufu, he considered the possibility that it could have been a faithful copy of an older original. In other words, Maspero thought the entire stele was a forgery made to look old, which, by definition, meant the forger had to copy exactly what he wanted to forge without altering what he saw. Maspero's forgery comment referred to the age of the physical stele discovered by Marriete, not the age of the story inscribed on it. We agree that this is possible with only two stipulations: That the original must have been created sometime during the $5^{\text {th }}$ Dynasty and that the text and depictions may have different original sources from different times since the gods depicted are not all mentioned in the text and since the Sphinx image is called Horemakhet, but, unlike in the text, there is no mention of Hurwn. Of the 14 deities depicted in the apparition window, only Isis, Osiris, and Horemakhet appear in the text. Hathor is mentioned in the text, but there is only an indirect reference to her in the inventory of statues, specifically the Uraeus. The haphazard arrangement of the text on the fourth register and pedestal also argue for separate sources.

Despite such initially more measured approaches taken by earlier scholars like Maspero, Hassan, and Zivie-Coche, the Inventory Stele's contribution to Egyptian history has become tainted, in part at least due to less sophisticated opinions and discussions widely disseminated through popular books, articles, Internet encyclopedias, and the like. We have attempted to address the questionable assumptions, inadvertent errors, omissions and oversights, the potentially problematic translations, and inappropriate insertions made during transcriptions, on which this bias may be based. Such biased approaches confound the analysis of a potentially historical record which we conclude the Inventory Stele may present while depriving Egyptology of a valuable piece of independent evidence, for example that Khufu built his pyramid at Giza, even if one wishes to disagree with the evidence concerning the Great Sphinx. The mere mention of Osiris, Isis, and Hurwn in the text should not prompt a knee-jerk reaction and obviate further scholarly scrutiny. We encourage others to examine the stele themselves and not base their opinions on perceived thought leaders in the field, who themselves may not have carefully examined the stele and its text but may have instead relied on others' translations and interpretations. This goes both ways. As Selim Hassan wrote (Hassan, 1953: p. 158):

Brugsch says that King Khufu had seen the Sphinx, and that, therefore, it must have existed before his time, an opinion which he had evidently founded on the famous Inventory Stela, an object that has proved itself to be a stumbling block in the path of historical research.

\section{Conclusion}

The story told about Khufu on the Inventory Stele appears plausible and realis- 
tic, once placed into the proper context of how the economic infrastructure of ancient Egypt was symbolized by goddesses. The story lines read like the lines of text on registers of early dynastic tags and labels chronicling events to identify vintage years. In other words, it was meant to record history. We think this story was transmitted to a scribe alive and active perhaps during the reign of Nuiserre when renewed interest in Giza arose after the royal court had left for Saqqara and Abusir a century prior. This was a time of political changes in which the royal families gave up some of their monopoly on power to non-royal statesmen increasingly moving to the provinces or rising from within them (Willems, 2014: pp. 23-24). The kings moved to more visibly project their power with added titles (Sedge-Bee; Son-of-Re) and by monumentalizing the heritage they received from their royal ancestors (Royal Annals). In short, this was a time when kings needed reaffirmation of their political power by showcasing the past, a Zeitgeist like that prevailing in the time of Psammtik I. This parallel best explains why the text of the Inventory Stele was resurrected to frame a list of divine statues.

Placed into this historical context, the text of the Inventory Stele appears as a royal reminder to a provincial audience that the provinces were, after all, the domains of the kings whose authority derived from the gods and which were territorially marked as such with temples and pyramids. Its composer would have known the precursor of the Pyramid Texts then still being written on papyrus. S/he would have known Osiris, Isis, Horakhty, and $\mathrm{Hu}(-\mathrm{Rn})$, the Great Sphinx. S/he would have been removed by less than five generations from those who witnessed Khufu's Giza project.

If there was an adaptation of the story, for example changing Satet to Isis, we conclude that this could be pinned on either the Late Period Scribe who copied this original stele from the $5^{\text {th }}$ Dynasty, or the original composer who lived in the time of the Pyramid Texts, when Osiris and Isis became more widely beheld icons of Egypt's Pantheon. The choice of protagonist, words and grammar, and the realistic elements of the story, however, do not support the notion that the entirety of the stele is a "pious fraud". A fraudster would not fake antiquity with sophisticated grammatical mimicry of Old Kingdom texts and then conspicuously misspell the name of Isis. S/he would not attempt to feign antiquity using Khufu and the Sphinx when Khafre was the more logical choice. In short, this was no fraud, because there were better ways to perpetrate fraud if fraud was intended. We agree with Gaston Maspero: The story lines on the Inventory Stele are not an original but are a good copy of one. Selim Hassan wrote as much referring to both the Dream Stele and the Inventory Stele (Hassan, 1953: p. 150):

But for the evidence of the inclusion of the name of Hwrna on the Inventory Stela, and the late form of the titles of the Gods, one would be tempted to state that both of these monuments had been copied from an older model, with the addition of a few minor alterations to meet the needs of the time.

We feel the Inventory Stele deserves another look by the language experts and 
it needs a new laser-scan guided transcription of the no longer legible symbols. Our analysis mostly focused on the content of the text, but a search for a Late Period "slip-up" which may weigh against the text's style's implied antiquity is beyond our expertise. Many insights have been gained into the language of the ancient Egyptians in just the last few decades. Old conclusions must be reexamined even if that means paradigms must fall. Most importantly we would like to see an evaluation of the grammar and lexical choices untainted by bias for or against the content which is at issue. Given that we were able to discover clues which do not fit the current narrative, it then follows that hieroglyphic experts, as well as outsiders, should come forward and look at the stele themselves to form their own opinions instead of relying on the opinions of others. As soon as they discover, as we have, that the motive and method of an alleged fraud are implausible, the Inventory Stele, we trust, will reveal to them more fact than fiction with significant historical implications particularly with respect to the true age of the Great Sphinx.

\section{Dedication}

We wish to dedicate this article to the memory of John Anthony West (9 July 1932-6 February 2018): "May his name forever be called on the horizon" by...*

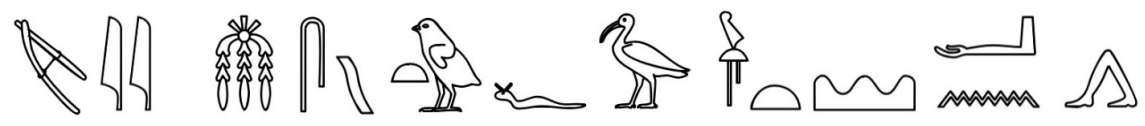

*those who wish that the soul of West is reborn.

\section{References}

AERA (Ancient Egypt Research Associates) (2017). Sphinx Project, Led by Mark Lehner. http://www.aeraweb.org/sphinx-project

Allen, J. P. (2005). The Ancient Egyptian Pyramid Texts. Atlanta: Society of Biblical Literature.

Allen, J. P. (2013). A New Concordance of the Pyramid Texts. Providence: Brown University, Vol. I-VI.

Allen, J. P. (2014). Middle Egyptian (3rd ed.). Cambridge: Cambridge University Press. https://doi.org/10.1017/CBO9781107283930

Bauval, R., \& Gilbert, A. (1994). The Orion Mystery: Unlocking the Secrets of the Pyramids. New York: Three Rivers Press.

Breasted, J. H. (1906). Ancient Records of Egypt Vol. I (pp. 83-85). Chicago: The University of Chicago Press.

Breasted, J. H. (1912). Development of Religion and Thought in Ancient Egypt. New York: Charles Scribner's Sons.

Brown University (n.d.). Photograph of Stele of Princess Shepset-Ipet. https://www.brown.edu/Departments/Joukowsky_Institute/courses/introtoegypt09/file s/9215608.jpg

Caminos, R. A. (1964). The Nitocris Adoption Stela. The Journal of Egyptian Archaeology, 50, 71-101. https://doi.org/10.1177/030751336405000109 
Cerný, J., \& Groll, S. I. (1993). A Late Egyptian Grammar (4th ed.). Rome: Editrice Pontifico Istituto Biblico.

Dreyer, G. (1999). Umm el-Qaab I: Das prädynastische Königsgrab U-j und seine frühen Schriftzeugnisse. Deutsches Archäologisches Institut, Abteilung Kairo, Archäologische Veröffentlichungen 86. Mainz: Verlag Philipp von Zabern.

Dreyer, G., \& Kaiser, W. (1980). Zu den kleinen Stufenpyramiden Ober-und Mittelägyptens (No. 36, p. 43f). Mitteilungen des Deutschen Archäologischen Instituts, Abteilung Kairo (MDAIK). Mainz: von Zabern.

El-Sadeek, W. (1984). An Analysis of the Tomb of Thery and its Place in the Development of Saite Funerary Art and Architecture. In Twenty-Sixth Dynasty Necropolis at Gizeh (Band 5, Nr. 29). Wien: Beiträge zur Ägyptologie.

Faulkner, R. O. (1973). The Ancient Egyptian Coffin Texts. Warminster: Aris and Phillips.

Friedmann, F. D. (2015). Chapter 2: Economic Implications of the Menkaure Triads. In Towards a New History for the Egyptian Old Kingdom: Perspectives on the Pyramid Age (Harvard Egyptological Studies). Leiden: Brill Academic Publishers. https://doi.org/10.1163/9789004301894_003

Gardiner Sign List; Based on Alan Gardiner (1957). Egyptian Grammar: Being an Introduction to the Study of Hieroglyphics. Oxford: Griffith Institute, Ashmolean Museum. http://web.ff.cuni.cz/ustavy/egyptologie/pdf/Gardiner_signlist.pdf http://www.egyptianhieroglyphs.net/gardiners-sign-list/

Hassan, S. (1949). The Sphinx: Its History in the Light of Recent Excavations. Cairo: Government Press.

Hassan, S. (1953). The Great Sphinx and Its Secrets. Historical Studies in the Light of Recent Excavations. Cairo: Government Press.

Hawass, Z. (1993). The Great Sphinx at Giza: Date and Function. Sesto Congresso Internazionale di Egittologia, II, 177-195.

Hawass, Z. (1996). The Discovery of the Satellite Pyramid of Khufu (GI-d). In P. Der Manuelian (Ed.), Studies in Honor of William Kelly Simpson (pp. 379-98). Boston: Museum of Fine Arts.

Helck, W. (1987). Untersuchungen zur Thinitenzeit. Wiesbaden: Otto Harrassowitz.

Junker, H. (1929). Giza I. Die Mastabas der IV. Dynastie auf dem Westfriedhof. Wien und Leipzieg: Hoelder-Pichler-Tempsky A.-G.

Kahl, J. (2003). Die frühen Schriftzeugnisse aus dem Grab U-j in Umm el-Qaab. Chronique d'Égypte, 78, 112-135.

Krauss, R. (1997). Astronomische Konzepte und Jehnseitsvorstellungen in the Pyramidentexten. Wiesbaden: Harrassowitz Verlag.

Labudek, J. (2010). Late Period Stelae from Saqqara. A Socio-Cultural and Religious Investigation. Master's Thesis, Birmingham: The University of Birmingham. http://etheses.bham.ac.uk/913/1/Labudek10MPhil.pdf

Lehner, M. (2002). The Pyramid Age Settlement of the Southern Mount at Giza. Journal of the American Research Center in Egypt, XXXIX, 27-74. https://doi.org/10.2307/40001149

Lewa Wildlife Conservancy (2015.) Lioness Roaring Mating Call. YouTube Video of a Lioness. https://youtu.be/PJc98NdlzU0

Naville, E. (1891). Bubastis. London: Messrs. Kegan Paul, Trench, Trubner \& Co.

Nome List (2018). List of Provinces ('nomes') of Ancient Egypt. 
http://www.ucl.ac.uk/museums-static/digitalegypt/geo/index.html

Orofino, V., \& Bernardini, P. (2016). Archaeoastronomical Study of the Main Pyramids of Giza, Egypt: Possible Correlations with the Stars? Archeological Discovery, 4, 1-10. https://doi.org/10.4236/ad.2016.41001

Petrie, W. M. F. (1892). Medum. London: David Nutt Publishing 270-271 Strand.

Reisner, G. A. (1931). Mycerinus. The Temples of the Third Pyramid at Giza. Cambridge, MA: Harvard University Press.

S.C.A. (Arab Republic of Egypt, Ministry of Culture, Supreme Council of Antiquities Press Release) (2010). http://www.digitaljournal.com/article/299126

Schoch, R. M. (2016). Ancient Fire and Lightning: Could Solar Outbursts Once Have Scorched the Giza Plateau? Atlantis Rising, No. 120, 44, 71-72.

Schoch, R. M., \& Bauval, R. (2017). Origins of the Sphinx: Celestial Guardian of Pre-Pharaonic Civilization. Rochester, NY: Inner Traditions.

Seyfzadeh, M., Schoch, R., \& Bauval, R. (2017). A New Interpretation of a Rare Old Kingdom Dual Title: The King's Chief Librarian and Guardian of the Royal Archives of Mehit. Archeological Discovery, 5, 163-177. https://doi.org/10.4236/ad.2017.53010

Stadelmann, R. (1997). Die Aegyptischen Pyramiden. Vom Ziegelbauzum Weltwunder. Mainz: Verlag Philipp von Zabern.

Stadelmann, R. (2000). The Great Sphinx of Giza. In Egyptology at the Dawn of the Twenty-First Century. Proceedings of the Eighth International Conference of Egyptologists (pp. 464-468). Cairo: The American University in Cairo Press.

Verner, M. (2001). The Pyramids: The Mystery, Culture, and Science of Egypt's Great Monument. London: Atlantic Books.

Vygus, M. (2015). Middle Egyptian Dictionary. http://www.pyramidtextsonline.com/documents/VygusDictionaryApril2015.pdf

Vyse, R. W. H. (Authorship on the Title Pages Listed as "Colonel Howard Vyse") (1840). Operations Carried On at the Pyramids of Gizeh in 1837: With an Account of a Voyage into Upper Egypt, and an Appendix. Two Volumes. London: James Fraser.

Wells, R. A. (1985). Sothis and the Satet Temple on Elephantine: A Direct Connection (pp. 255-302). Studien zur Altägyptischen Kultur. Hamburg: Helmut Buske Verlag $\mathrm{GmbH}$.

Wilkinson, R. H. (2003). The Complete Gods and Goddesses of Ancient Egypt. London: Thames \& Hudson.

Willems, H. (2014). Historical and Archeological Aspects of Egyptian Funerary Culture. Leiden-Boston: Brill. https://doi.org/10.1163/9789004274990

Zivie-Coche, C. M. (1991). Giza au Premier Millenaire. Boston: Museum of Fine Arts. 


\section{Hieroglyphs}

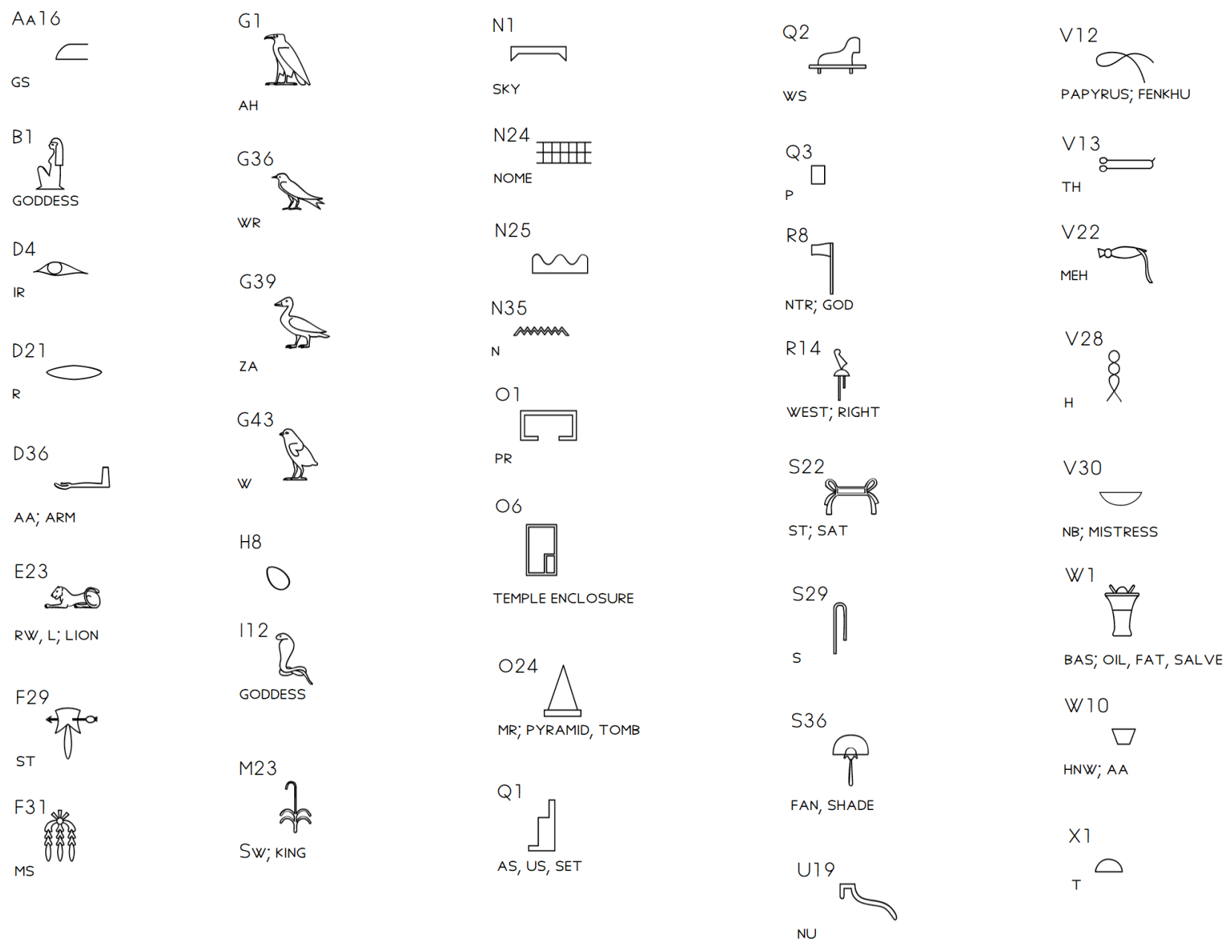

